Prepared for the U.S. Department of Energy

under Contract DE-AC05-76RL01830

\title{
National Geo-Database for Biofuel Simulations and Regional Analysis
}

\author{
R. César Izaurralde \\ Ritvik Sahajpal \\ Xuesong Zhang \\ David H. Manowitz
}

April 2012

Pacific Northwest

NATIONAL LABORATORY

Proudly Operated by Battelle Since 1965 


\title{
DISCIAIMER
}

This report was prepared as an account of work sponsored by an agency of the United States Government. Neither the United States Government nor any agency thereof, nor Battelle Memorial Institute, nor any of their employees, makes any warranty, express or implied, or assumes any legal liability or responsibility for the accuracy, completeness, or usefulness of any information, apparatus, product, or process disclosed, or represents that its use would not infringe privately owned rights. Reference herein to any specific commercial product, process, or service by trade name, trademark, manufacturer, or otherwise does not necessarily constitute or imply its endorsement, recommendation, or favoring by the United States Government or any agency thereof, or Battelle Memorial Institute. 'The views and opinions of authors expressed herein do not necessarily state or reflect those of the United States Government or any agency thereof.

\author{
PACIFIC NORTHWFST NATIONAI I ABORATORY \\ operated by \\ BAT"TELLE \\ for the \\ UNITED STATES DEPARTMFNT OF ENERGY \\ under Contract DE-AC05-76RL01830
}

Printed in the United States of America

Available to DOE and DOE contractors from the

Office of Scientific and Technical Information,

P.O. Box 62, Oak Ridge, TN 37831-0062;

ph: (865) 576-8401

fax: (865) 576-5728

email: reports@adonis.osti.gov

\author{
Available to the public from the National Technical Information Service, \\ U.S. Department of Commerce, 5285 Port Royal Rd., Springfield, VA 22161 \\ ph: (800) 553-6847 \\ fax: (703) 605-6900 \\ email: orders@ntis.fedworld.gov \\ online ordering: http://www.ntis.gov/ordering.htm
}

This document was printed on recycled paper

(9/2003) 


\title{
National Geo-Database for Biofuel Simulations and Regional Analysis
}

\author{
R César Izaurralde Ritvik Sahajpal \\ Xuesong Zhang David H. Manowitz
}

April 2012

Prepared for

the U.S. Department of Energy

under Contract DE-AC05-76RL01830

Pacific Northwest National Laboratory

Richland, Washington 99352 
PNNL-21284 


\section{Executive Summary}

The goal of this project undertaken by GLBRC (Great Lakes Bioenergy Research Center) Area 4 (Sustainability) modelers is to develop a national capability to model feedstock supply, ethanol production, and biogeochemical impacts of cellulosic biofuels. The results of this project contribute to sustainability goals of the GLBRC; i.e. to contribute to developing a sustainable bioenergy economy: one that is profitable to farmers and refiners, acceptable to society, and environmentally sound. A sustainable bioenergy economy will also contribute, in a fundamental way, to meeting national objectives on energy security and climate mitigation.

The specific objectives of this study are to: (1) develop a spatially explicit national geodatabase for conducting biofuel simulation studies; (2) model biomass productivity and associated environmental impacts of annual cellulosic feedstocks; (3) simulate production of perennial biomass feedstocks grown on marginal lands; and (4) locate possible sites for the establishment of cellulosic ethanol biorefineries.

To address the first objective, we developed SENGBEM (Spatially Explicit National Geodatabase for Biofuel and Environmental Modeling), a 60-m resolution geodatabase of the conterminous USA containing data on: (1) climate, (2) soils, (3) topography, (4) hydrography, (5) land cover / land use (LCLU), and (6) ancillary data (e.g., road networks, federal and state lands, national and state parks, etc.). A unique feature of SENGBEM is its 2008-2010 crop rotation data, a crucially important component for simulating productivity and biogeochemical cycles as well as land-use changes associated with biofuel cropping.

We used the EPIC (Environmental Policy Integrated Climate) model to simulate biomass productivity and environmental impacts of annual and perennial cellulosic feedstocks across much of the USA on both croplands and marginal lands. We used data from LTER and eddy-covariance experiments within the study region to test the performance of EPIC and, when necessary, improve its parameterization. We investigated three scenarios. In the first, we simulated a historical (current) baseline scenario composed mainly of corn-, soybean-, and wheat-based rotations as grown existing croplands east of the Rocky Mountains in 30 states. In the second scenario, we simulated a modified baseline in which we harvested corn and wheat residues to supply feedstocks to potential cellulosic ethanol biorefineries distributed within the study area. In the third scenario, we simulated the productivity of perennial cropping systems such as switchgrass or perennial mixtures grown on either marginal or Conservation Reserve Program (CRP) lands. In all cases we evaluated the environmental impacts (e.g., soil carbon changes, soil erosion, nitrate leaching, etc.) associated with the practices.

ARRA support for this project and to the PNNL Joint Global Change Research Institute enabled us to create an advanced computing infrastructure to execute millions of simulations, conduct post-processing calculations, store input and output data, and visualize results. These computing resources included two components installed at the Research Data Center of the University of Maryland. The first resource was "deltac": an 8-core Linux server, dedicated to county-level and state-level simulations and PostgreSQL database hosting. The second resource was the DOE-JGCRI "Evergreen" cluster, capable of executing millions of simulations in relatively short periods. ARRA funding also supported a $\mathrm{PhD}$ student from University of Maryland who worked on creating the geodatabases and executing some of the simulations in this study. 
In the baseline scenario, EPIC simulation results captured $63 \%$ of the variance in reported NASS yields of corn, soybean, and winter wheat across 30 states. Agreement between simulated and observed corn yields was highest in Iowa and Illinois. EPIC underestimated yields with respect to those observed in the irrigated areas of Nebraska, Kansas, and Texas. Similar results were obtained for soybean. The wheat simulations were less accurate due, in part, to errors in classification of wheat lands in the CDL product used to model wheat production. Based on the simulation results, we estimated that corn and wheat residues could serve as feedstocks to produce $\sim 13$ billion gallons of cellulosic ethanol per year. However, our simulations show ensuing increases in soil erosion and carbon losses with the full implementation of these practices.

Using a physically based classification of marginal lands, we simulated production of cellulosic feedstocks from switchgrass and perennial mixtures grown on these lands in the US Midwest. Our simulated $\mathrm{N}$-fertilized "lowland" switchgrass yields compared favorably with those of 18 field trials except for two in West Virginia and Tennessee. Marginal lands in the western states of the US Midwest appear to have significant potential to supply feedstocks to a cellulosic biofuel industry. Similar results were obtained with simulations of $\mathrm{N}$-fertilized perennial mixtures. A detailed spatial analysis allowed for the identification of possible locations for the establishment of 34 cellulosic ethanol biorefineries with total annual production capacity of 5.6 billion gallons.

In summary, we have reported on the development of a spatially explicit national geodatabase to conduct biofuel simulation studies and provided initial simulation results on the potential of annual and perennial cropping systems to serve as feedstocks for the production of cellulosic ethanol. To accomplish this, we have employed sophisticated spatial analysis methods in combination with the process-based biogeochemical model EPIC. The results of this study will be submitted to the USDOE Bioenergy Knowledge Discovery Framework as a way to contribute to the development of a sustainable bioenergy industry. This work provided the opportunity to test the hypothesis that marginal lands can serve as sources of cellulosic feedstocks and thus contribute to avoid potential conflicts between bioenergy and food production systems. This work, we believe, opens the door for further analysis on the characteristics of cellulosic feedstocks as major contributors to the development of a sustainable bioenergy economy. Examples of research questions that could be pursued with the modeling framework presented here include:

- How can the modeling framework be improved? (e.g., adding irrigation, improving winter wheat simulations)

- What is the performance of emerging biofuel feedstocks such as miscanthus, energy cane, and energy sorghum? Where are the best regions to grow them?

- What is the potential of marginal lands across the conterminous USA to provide sustainable levels of biomass feedstocks to the cellulosic ethanol industry?

- What are the full GHG impacts of diverse biofuel production systems? 


\section{Acknowledgments}

We gratefully acknowledge the support from the following:

- DOE EERE Office of Biomass Program: Alison Goss, Ranyee Chiang, Alicia LindauerThompson

- DOE Office of Science

- DOE Great Lakes Bioenergy Research Center

- PNNL: Tristram West, Prasad Bandaru, Jonathan Male, Don Stevens, Gregg Andrews, Paul Girgis, Kay Killingstad, Kali Wood

- Michigan State University Kellogg Biological Station: Phil Robertson, Ilya Gelfand

- Texas A\&M University: Jimmy Williams

- ORNL: Stan Wullschleger, Wilfred Post

- USDA - FAS: Rich Iovanna

- $\quad$ EPA ORD: Stephen LeDuc 


\section{Acronyms and Abbreviations}

ARRA

C3

C4

CDR

CDL

EERE

EISA

EPIC

GIS

HSMU

JGCRI

KBS

LCA

LCGHGE

LTER

NASS

NEE

NPP

NOAA

NRC

OBP

PNNL

RFS

SEIMF

SENGBEM

SSURGO

USDA

USDOE

UMD

$\mathrm{Mg}$

$\mathrm{Gg}$
2009 American Recovery and Reinvestment Act (Pub. L. 111-5)

A plant in which the $\mathrm{CO}_{2}$ is first fixed into a compound containing three carbon atoms before entering the Calvin cycle of photosynthesis

A plant in which the $\mathrm{CO}_{2}$ is first fixed into a compound containing four carbon atoms before entering the Calvin cycle of photosynthesis

Cedar Creek, Minnesota

USDA Crop Data Layer

USDOE Energy Efficiency and Renewable Energy

2007 Energy Independence and Security Act (Pub. L. 110-140)

Environmental Policy Integrated Climate model

Geographic Information System

Homogenous Spatial Modeling Unit

Joint Global Change Research Institute

Kellogg Biological Station, Michigan

Life Cycle Analysis

Lifecycle Greenhouse Gas Emission

Long Term Ecological Research

USDA National Agricultural Statistical Census

Net Ecosystem Exchange

Net Primary Productivity

National Oceanographic and Atmospheric Administration

National Research Council of the United States of America

USDOE EERE Office of Biomass Program

Pacific Northwest National Laboratory

Renewable Fuel Standard, a component of the 2005 Energy Policy Act of the United States of America

Spatially Explicit Integrated Modeling Framework

Spatially Explicit National Geodatabase for Biofuels and Environmental Modeling USDA Soil Survey Geographic Database

United States Department of Agriculture

United States Department of Energy

University of Maryland

\section{Units}

Equivalent to 1 metric ton or $1,000 \mathrm{~kg}$

Equivalent to $1,000 \mathrm{Mg}$ 


\section{Contents}

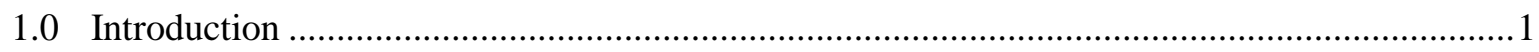

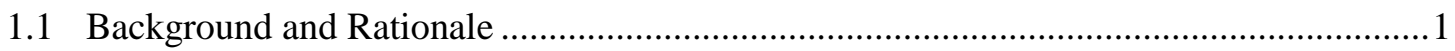

1.2 Overall Goal and Specific Objectives ......................................................................

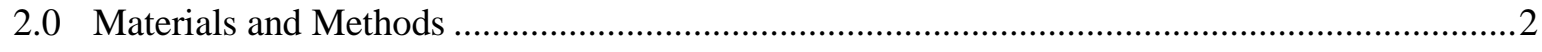

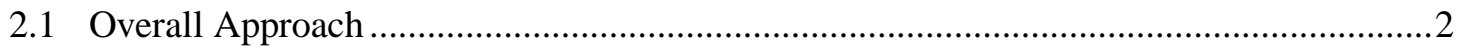

2.2 Preparation of a Spatially Explicit National Geodatabase for Biofuel and

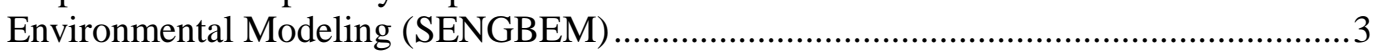

2.3 Preparing and Implementing Spatially Explicit Simulations with the EPIC Model ..........5

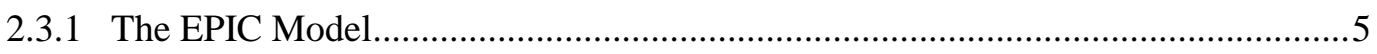

2.3.2 Spatially Explicit Modeling Framework .........................................................6

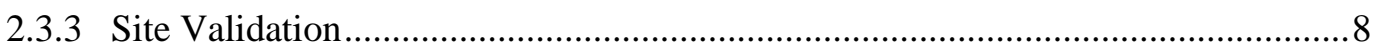

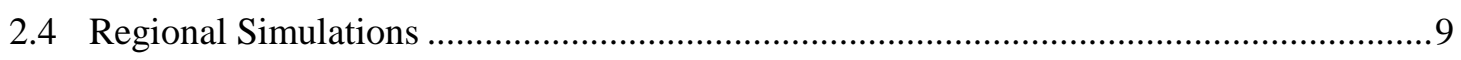

2.4.1 Simulation of Potential Biomass Supply and Environmental Impacts of Collecting Residue from Cultivated Lands in 30 states of US ............................. 9

2.4.2 Simulation of Potential Cellulosic Feedstock Supply from Perennial Biomass Crops Grown on Marginal Lands ...................................................................... 11

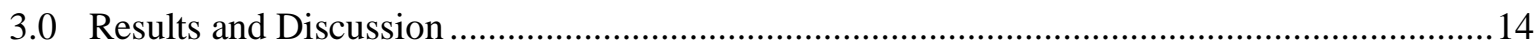

3.1 Features of the National Geodatabase to Simulate Biofuel Production ............................14

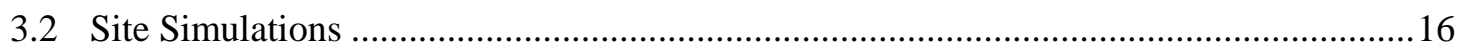

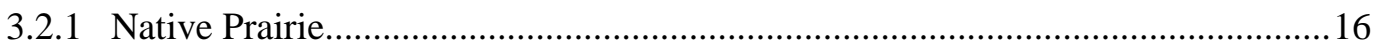

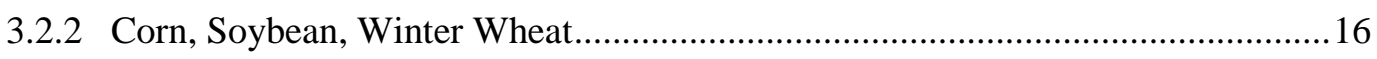

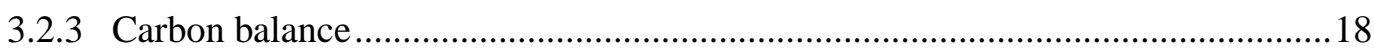

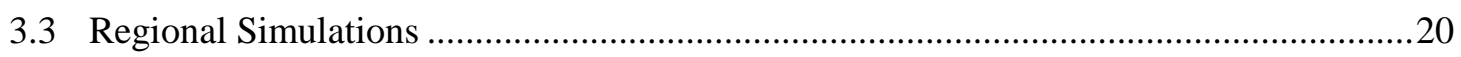

3.4 Potential Biofuel Production and Environmental Impacts of Collecting Residue from

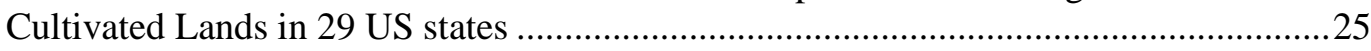

3.5 Potential Biomass Production from Switchgrass on Low Productive Agricultural Lands29

3.6 Potential Cellulosic Biomass Production from Marginal Lands .................................... 32

3.6.1 Comparison with Estimates from Billion Ton Study Update..................................32

3.6.2 Locating Biorefineries in 10 States of the US Midwest Region ............................33

3.6.3 Cellulosic Biomass Production in the Sandhills of Nebraska ................................34

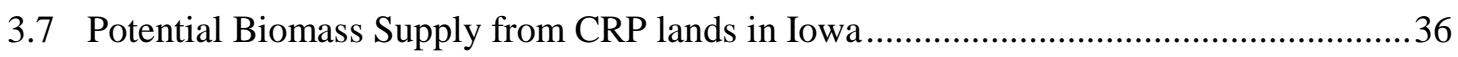

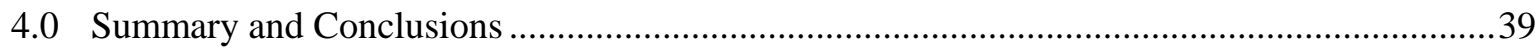

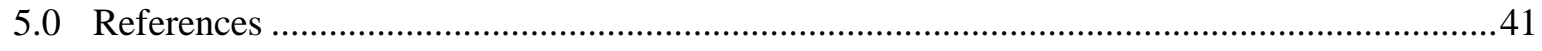

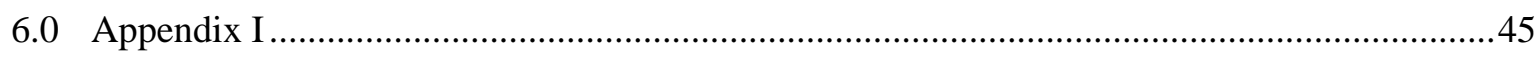

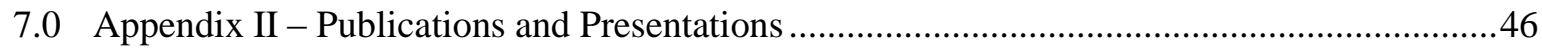




\section{Figures}

Figure 1 Structure of the Spatially Explicit Modeling Framework (Zhang et al., 2010)...................3

Figure 2. Illustration of the hierarchical and flexible downscaling and upscaling schemes in

United States lands (Zhang et al., 2010).......................................................................

Figure 3. Diagram showing procedures to define HSMUs (Homogeneous Spatial Modeling Units). 7

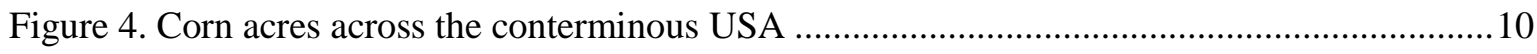

Figure 5. Soybean acres across the conterminous USA .............................................................. 10

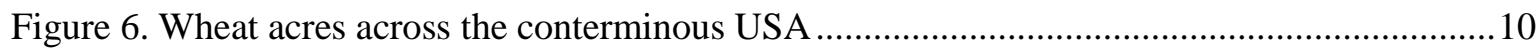

Figure 7. Irrigated acres of cropland across the conterminous USA (AgCensus, 2007)................11

Figure 8. Marginal lands area $\left(\times 10^{6} \mathrm{ha}\right)$ in 10 -states of the US Midwest region, as modeled by

EPIC (left Y axis) and arable land area (right Y axis) from Cropland Data Layer of 2008. ....13

Figure 9. National Geodatabase of Contemporary Land Cover and Use in the Conterminous USA.15

Figure 10. Annual crop yields of corn, soybean, and winter wheat on two contrasting plots.

Figure 11. Simulated and observed long-term (1989-2005) impact of crop management practices

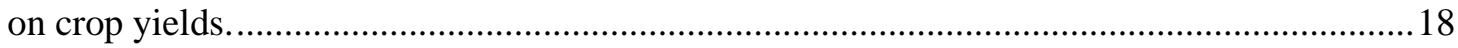

Figure 12. Simulated and observed NEE under three contrasting cropping systems. .....................19

Figure 13. Comparison between EPIC-simulated and NASS-reported county level crop yields.....20

Figure 14. EPIC-simulated (dry) corn yields simulated at HSMU scale and aggregated to county

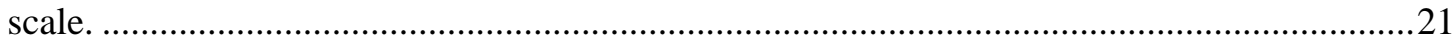

Figure 15. County (dry) corn yields reported by NASS. ........................................................2

Figure 16. EPIC simulated (dry) soybean yields simulated at HSMU scale and aggregated at

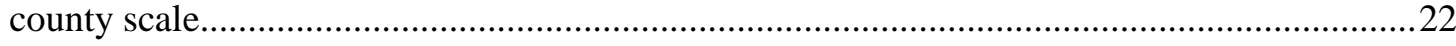

Figure 17. County (dry) soybean yields reported by NASS. ....................................................23

Figure 18. EPIC-simulated (dry) winter wheat yields simulated at HSMU scale and aggregated to

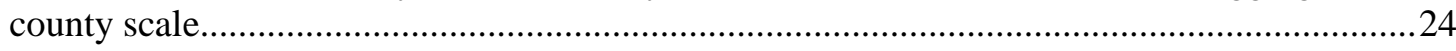

Figure 19. County (dry) winter wheat yields reported by NASS ..............................................24

Figure 20. EPIC-simulated biomass production from corn residues assuming collection of 50\%

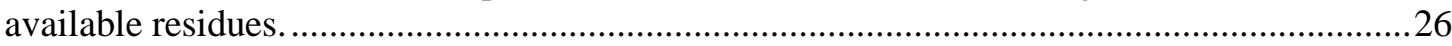

Figure 21. EPIC-simulated biomass production from winter wheat residues assuming collection

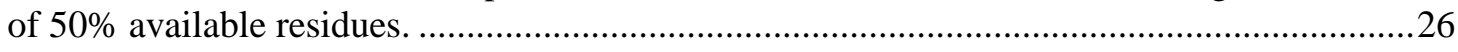

Figure 22. Ratio of water erosion between residue removal and no-residue removal scenarios......27

Figure 23. Difference in soil organic C (SOC) change between residue and no-residue removal scenarios.

Figure 24. Difference in nitrate leaching between residue and no-residue removal scenarios........29

Figure 25. EPIC simulated switchgrass yields across 30 states in the conterminous USA. Sets of three bars represent a comparison between simulated and observed yields at 18 locations..... 30

Figure 26. Area of cultivated land with land capability classes IV - VII.................................... 31

Figure 27. EPIC simulated yields of switchgrass on cultivated land with land capability classes IV $-\mathrm{VI}$. 
Figure 28. Potential cellulosic ethanol production from switchgrass on cultivated lands with land capability classes IV - VII.

Figure 29. Biomass yields and potential cellulosic ethanol biorefinery locations in the 10-state US

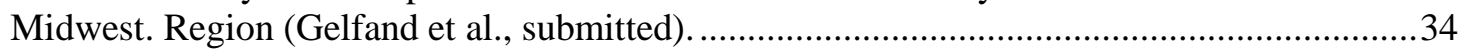

Figure 30. The placement of biorefineries for cellulosic biomass production from marginal lands in 10 states of the US Midwest with identification numbers corresponding to Table 8 (Gelfand et al., submitted).

Figure 31. Soil-C change ratio in harvested vs. unharvested perennial mixtures.............................37

Figure 32. Nitrogen export by treatment relative to no-harvest perennial mixture...........................38

Figure 33. Location of potential ethanol biorefineries (circles with $80 \mathrm{~km}$ radius) drawing cellulosic feedstock from perennial mixtures grown on CRP lands. 


\section{Tables}

Table 1. Percentage of Bias of EPIC-simulated corn yield across 29 states...................................22

Table 2. Percentage of Bias of EPIC simulated soybean yield across 28 states ..............................23

Table 3. Percentage of Bias of EPIC simulated winter wheat yields across 29 states....................25

Table 4. Potential ethanol production from corn and winter wheat residues in the US Midwest

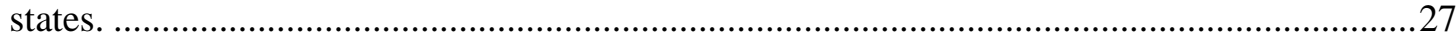

Table 5. Location, maximum and minimum of lowland switchgrass yields at 18 field trials. .........30

Table 6. Average biomass yields $\left(\mathrm{Mg} \mathrm{ha}^{-1} \mathrm{yr}^{-1}\right)$ for 78,184 parcels of marginal land as modeled by EPIC for two harvest efficiencies and three $\mathrm{N}$ levels (Gelfand et al., submitted). ....................32

Table 7. EPIC simulated and Billion-Ton Study Update (BTS-U) estimated biomass yields on marginal lands across the 10-state US Midwest Region (Gelfand et al., submitted).

Table 8. EPIC modeled biomass and cellulosic ethanol production by state assuming $90 \%$ harvest

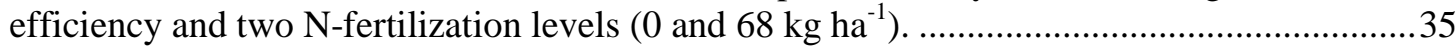




\subsection{Introduction}

\subsection{Background and Rationale}

Biofuels have been emerging as viable alternatives to fossil fuels. Two major factors have determined their rise in prominence in the United States: energy security and climate change (NRC, 2011). Energy security concerns about high oil prices and a continued dependence of the U.S. on foreign oil, led the U.S. Congress to establish the Renewable Fuel Standard (RFS) as part of the 2005 Energy Policy Act. This RFS established the first renewable fuel target in the U.S. in the form of a requirement to blend 7.5 billion gallons of renewable fuel with gasoline by 2012 . The 2007 Energy Independence and Security Act (EISA) expanded the RFS mandate by requiring an increase in the fuel blending from 9 billion gallons in 2008 to 36 billion gallons by 2022. Of the 36 billion gallons by $2022,58 \%$ has to originate from advanced biofuels; i.e. a renewable fuel that has a lifecycle greenhouse gas emission (LCGHGE) that is at least 50\% lower than that of the baseline renewable fuel LCGHGE in 2005 (EISA, 2007). Cellulosic ethanol, an advanced biofuel, is expected to cover $44 \%$ of the 2022 target.

The second factor relates to climate change and the societal need to reduce anthropogenic greenhouse-gas emissions to the atmosphere. Biofuels are promising because they can contribute to replacing energy use from fossil fuels and reducing GHG emissions to the atmosphere (Kim and Dale, 2004). Satisfying bioenergy production targets in the U.S. will create a demand for land for growing biomass crops and some have expressed concern about the ultimate impact of these transformations on food prices and the environment (Crutzen et al., 2008; Fargione et al., 2008; Searchinger et al., 2008).

Ensuring the sustainable production of biofuels is a key mission of the Great Lakes Bioenergy Research Center (GLBRC) created in 2007 by the U.S. DOE Office of Science and led by the University of Wisconsin and Michigan State University (Slater et al., 2010). The GLBRC comprises four major discovery areas: (1) improved plant production, (2) improved processing, (3) improved catalytical processes, and (4) sustainable biofuels production practices. Six major research activities describe the sustainability area: novel production practices, plant-microbial interactions, biogeochemical practices, biodiversity impacts, economic analysis, and integrated modeling (biophysical, biogeochemical, economic, and life-cycle analysis).

Most of the integrated modeling research at the GLBRC has been conducted at biorefinery scale, a multi-county area where a theoretical cellulosic ethanol biorefinery could draw enough plant biomass to produce 100 million gallons of ethanol per year. These areas are known within the GLBRC research community as RIMAs (Regionally Intensive Modeling Areas). Zhang et al. (2010) reported on SEIMF (Spatially Explicit Integrated Modeling Framework), a spatially explicit approach designed to model biomass productivity and environmental impacts of diverse biofuel crops. Egbendewe-Mondzozo et al. (2011) expanded on the work by Zhang et al. (2010) by developing a spatially explicit bioeconomic model of biomass supply from alternative cellulosic crops and crop residues as well as exploring policy scenarios for handling various environmental outcomes. Current modeling work has focused on integrating the SEIMF approach with biogeochemical and biodiversity experiments together with life-cycle analysis (LCA) modeling. Emerging results from field 
experiments have been utilized to test as well as improve modeling capabilities of current and novel biofuel-production practices.

In fall 2008, the USDOE EERE Office of Biomass Program (OBP) provided support to the GLBRC for enhancing field research and modeling activities of sustainable biofuels production practices. Here we report on efforts to develop a national-scale database and methodology to simulate biofuel crops and on regional modeling results of biomass productivity and potential ethanol production resulting from the collection and processing of this biomass.

\subsection{Overall Goal and Specific Objectives}

The goal of this work is to develop predictive land-use change modeling capabilities to address the sustainable production of biomass. The results of experimental field research will be combined with theoretical modeling capabilities to create the ability to examine land-use changes in a broad context with relation to many sustainability criteria such as water use, $\mathrm{CO}_{2}$ emissions, and related factors.

Toward this goal, the specific objectives of this modeling study are to:

1. Develop a spatially explicit national geodatabase to conduct biofuel simulation studies

2. Conduct simulation studies to estimate biomass productivity of various biomass feedstocks (crop residue, perennial species) and associated environmental impacts

3. Perform simulation studies of perennial biomass feedstocks grown on marginal lands including lands currently under the Conservation Reserve Program (CRP)

4. Estimate possible locations of cellulosic ethanol biorefineries able to be supplied with feedstock of biomass grown on marginal lands

\subsection{Materials and Methods}

\subsection{Overall Approach}

The overall approach used in this project was to extend the integrated modeling research experience gained with the SEIMF approach (Zhang et al., 2010) at RIMA (multi-county) scale to larger (multi-state) regions. As described by Zhang et al. (2010), the SEIMF contains three modules: 1) a GIS-based geodatabase, 2) a terrestrial ecosystem model, and 3) a multi-objective optimization algorithm (Figure 1). The input data is processed into a geodatabase where homogeneous spatial modeling units (HSMUs) from moderate to high spatial-resolution data are defined and input data for the terrestrial ecosystem model EPIC (Williams et al., 1989; Kiniry et al., 1995) are extracted. The last module of SEIMF is a multiobjective optimization algorithm designed for the evaluation of the production and environmental tradeoffs of diverse biofuel production practices. 


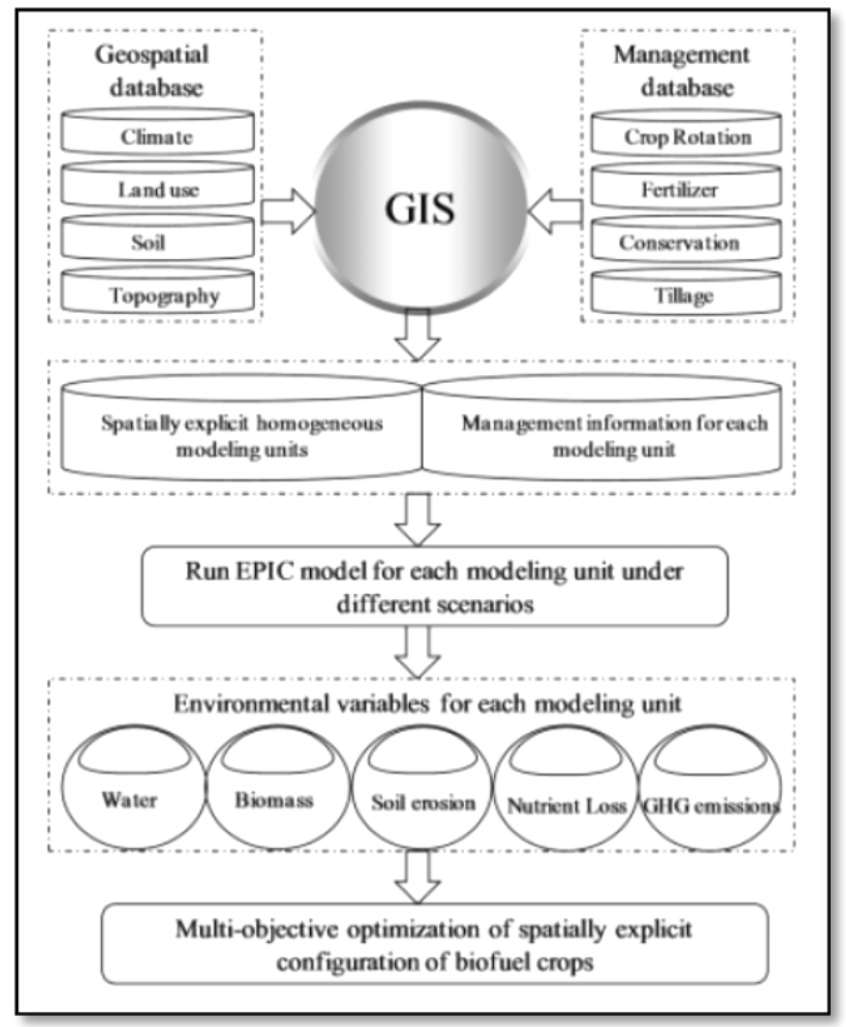

Figure 1 Structure of the Spatially Explicit Modeling Framework (Zhang et al., 2010).

\subsection{Preparation of a Spatially Explicit National Geodatabase for Biofuel and Environmental Modeling (SENGBEM)}

The main purpose for developing a high-resolution spatial and temporal geodatabase was to be able to model, at field scale, the performance of diverse biofuel crops under various management scenarios. In particular, there was the need to examine the potential of marginal lands for the placement of perennial biofuel crops. The procedure described by Zhang et al. (2010) demonstrated the possibility of identifying and modeling the productivity and environmental impacts of biofuel crops grown on marginal lands.

In this project, we developed SENGBEM (Spatially Explicit National Geodatabase for Biofuel and Environmental Modeling), a geodatabase containing five main types of data: 1) climate, 2) soils, 3) topography, 4) hydrography, and 5) land cover / land use (LCLU). In addition, SENGBEM contains other types of ancillary data such as road networks, federal and state lands, national and state parks, etc. Following is a description of the data used in constructing SENGBEM.

Climate Data. The climate database contains historical daily values of weather variables needed to drive EPIC and other biophysical models. The weather variables are air temperature (maximum and minimum, $\left.{ }^{\circ} \mathrm{C}\right)$, precipitation $(\mathrm{mm})$, solar radiation $\left(\mathrm{MJ} \mathrm{m}^{-2}\right)$, wind speed $\left(\mathrm{m} \mathrm{s}^{-1}\right)$, and relative humidity (as a fraction). Climate data can be extracted from multiple sources, including Daily Surface Weather and Climatological Summary (DayMet) (http://www.daymet.org/), the North American Regional Reanalysis (NARR) (http://www.esrl.noaa.gov/psd/data/gridded/data.narr.html), and the 
North American Land Data Assimilation System (NLDAS)

(http://www.emc.ncep.noaa.gov/mmb/nldas/). The datasets differ in terms of spatial resolution and length of period of record.

The DayMet dataset provides the highest spatial resolution $(1 \mathrm{~km})$ and accounts for the influence of orography on weather. DayMet was developed at the University of Montana, Numerical Terradynamic Simulation Group (NTSG) to provide the biophysical modeling community the daily meteorological and climatological data necessary to run simulation models. The NARR and NLDAS datasets are both from NOAA and the main difference between them is the spatial resolution: $32 \mathrm{~km}$ for NARR and $12 \mathrm{~km}$ for NLDAS. The main advantage of the NOAA datasets over DayMet is that they are available from 1979 to the present, with approximately a 6-month lag. While DayMet data are also available from about the same start period (1980), the delay for more recent data is much longer.

Topography and Hydrography Data. Topographic data are essential to delineate watersheds and determine slope characteristics (elevation, gradient, length, and aspect) needed for hydrological and erosion modeling. Topographic data for SENGBEM were derived from the Shuttle Radar Topography Mission (SRTM), which produced the highest resolution digital elevation model (DEM) of the Earth at a resolution of $30 \mathrm{~m}$ (Farr et al., 2007). In addition, the National Hydrography Dataset (NHD-plus) (Simley and Carswell, 2009) was used to extract hydrologic catalogue unit (HCU) boundary information for modeling soil sediment yield, surface runoff, subsurface flow, and nutrient transport with runoff.

Soil Data. There are two major soil databases available in the U.S. for environmental modeling: State Soil Geographic (STATSGO) and Soil Survey Geographic (SSURGO) both developed by USDA-NRCS. The STATSGO database is designed mainly for regional, multistate, river basin, state and multicounty resource planning, management, and monitoring. Instead, the SSURGO database primarily enables farm/ranch, landowner/user, township, county, or parish natural resource planning and management. The main difference between the two is the level of detail contained in the map units: STATSGO map units can have up to 21 different component soils while SSURGO map units usually contain one component and can contain up to a maximum of three components. The SSURGO database, now available for almost the entire conterminous U.S., was selected for building SENGBEM due to its high resolution. Data from SSURGO (http://datagateway.nrcs.usda.gov) were extracted to map soils at scales of $\sim 1: 24,000(\sim 30 \mathrm{~m})$. Data retrieval also included a suite of physical and chemical soil properties needed for biophysical and biogeochemical modeling: albedo, layer depth (m), bulk density $\left(\mathrm{Mg} \mathrm{m}^{-3}\right)$; mineral fractions (sand, silt, clay, coarse fragments), organic $\mathrm{C}(\%)$, total $\mathrm{N}\left(\mathrm{mg} \mathrm{kg}^{-1}\right)$; and $\mathrm{pH}$.

The SSURGO database provides an interpretive classification variable [i.e. land capability (LC)] that represents land classes based on use limitation (e.g., soil depth, erosion risk, slope, etc.) (Klingebiel and Montgomery, 1961). There are eight LC classes: I-VIII. Class I is (prime) land without any limitations for use. Class VIII is land can only support wildlife, not agriculture. Classes I-IV can support cropland agriculture, whereas classes V-VIII contain non-arable land. LC can be used for two purposes: (1) identifying marginal land (e.g. low yield cropland) for biofuel production and (2) qualitatively validating the results of biophysical and biogeochemical modeling. Land capability classes are subdivided into land capability subclasses according to the kind of limitation 
(susceptibility to erosion, excess water, shallowness of the rooting zone, climate hazard). All map unit components, including miscellaneous areas, are assigned a capability class and subclass.

Land Cover and Land Use Data. Crop rotation information (e.g. corn (Zea mays L.) - soybean (Glycine max (L.) Merr.), continuous corn) is important for driving cropland ecosystem simulations via a spatially explicit terrestrial ecosystem model. Land cover / land use data to build SENGBEM were derived from the USDA Cropland Data Layer (CDL) remote sensing product available at national scale at a resolution of 56m x 56m since 2008 (http://datagateway.nrcs.usda.gov). The CDL land cover was developed by the USDA to utilize seasonal satellite imagery to monitor how the acreage of major crop types varies from one year to the next. To generate a high-resolution crop rotation map of the U.S, multiple years (2008, 2009, and 2010) of CDL images were overlaid to derive historical crop rotations. A novel time-series analysis based algorithm was implemented to aggregate all observed rotations into representative rotations. In all, nearly 170 unique crop rotations covering the entire USA were generated. The product is highly accurate with $>95 \%$ accuracy for corn and soybean growing regions in U.S. when compared to census data from NASS (USDA National Agricultural Statistical Services).

Crop rotations are then combined with data on soil, elevation, and hydrography to provide historical input data for the biophysical and biogeochemical modeling. For future biofuel-scenario analyses, current CDL land use classes are summarized into several major categories, including field crops (FC), herbaceous vegetation (HV), and woody vegetation (WV), to reduce the number of modeling units and the computational burden of SEIMF implementation.

Crop Management Data. Crop management practices have important implications for crop production and environmental consequences. For the baseline simulation, we collected tillage intensity data at county scale by the Conservation Technology Information Center (CTIC, 2007); fertilizer application and crop management survey data at state level (USDA 2011); and typical planting and harvesting dates of major crops in the USA (USDA NASS 1997). Due to the lack of crop specific irrigation data, we did not consider irrigation operations within crop rotations. Instead, we only simulated crop yield and environmental impacts under rainfed conditions. We assumed fertilizer application rates as well as planting and harvesting dates to be the same for all units in one state. When allocating county level tillage intensity fraction data to each modeling unit, we assume conservation tillage (no-till, ridge-till, and mulch-till) to be assigned to the most steep area, followed by reduced tillage to less steep units and conventional tillage to flat units.

\subsection{Preparing and Implementing Spatially Explicit Simulations with the EPIC Model}

\subsubsection{The EPIC Model}

The EPIC model can simulate the growth and development of over 100 plant species including all major crops, grasses, legumes, and some trees (Williams, 1995). Crops can be grown as sole crops or as intercrops (up to 10 species), in complex rotations, and under a wide range of management operations including tillage, irrigation, fertilization, and liming. EPIC uses the concept of radiationuse efficiency (Monteith, 1977) by which a fraction of daily photosynthetically active radiation is intercepted by the plant canopy and converted into plant biomass. Daily gains in plant biomass are 
affected by vapor pressure deficits and atmospheric $\mathrm{CO}_{2}$ concentration (Stockle et al., $1992 \mathrm{a}, \mathrm{b}$ ). Plant phenology is controlled via heat-unit calculations in which each crop / plant species has base and optimal air temperatures for growth. Potential daily gains in biomass are affected by environmental stresses such as water, temperature, nutrients (primarily $\mathrm{N}$ and $\mathrm{P}$ ), and aeration. All stresses are calculated every day during the simulation, but only the value of the most severe stress is used to reduce potential plant growth and crop yield. Stress factors for soil strength, temperature, and aluminum toxicity are also calculated daily and used to adjust potential root growth (Jones et al., 1991). EPIC is driven by daily weather consisting of solar radiation, air temperature, precipitation, wind speed, and relative humidity. These daily inputs are either predicted from statistical weather parameters or read from input files. Simulated processes account for topographical (e.g. slope gradient and length) characteristics and field / watershed dimensions, soil layer properties (e.g., layer depth, bulk density, $\mathrm{C}$ and $\mathrm{N}$ contents, $\mathrm{pH}$ ), and management information (e.g. cropping systems, planting, fertilization, irrigation, harvesting), as inputs to EPIC (Gassman et al., 2005; Williams et al., 1995; Zhang et al., 2010).

For this work, the parameterization of the EPIC model was revised to ensure adequate representation of biofuel cropping systems (Izaurralde et al., 2012). Specific crop parameters / variables that underwent evaluation and eventual change included radiation-use efficiency, root-toshoot ratio (Zhang et al., 2011), and planting density. Further, the rate of transformation of standing live to standing dead vegetation was reduced from $1 \%$ to $0.1 \%$ per day to better model the reduced loss of yield in fall-harvested cellulosic crops.

\subsubsection{Spatially Explicit Modeling Framework}

The high spatial resolution of operational modeling units (from tens to hundreds of meters, with finer resolutions preferred) provides more homogeneous land units and improves model accuracy. However, agricultural statistics (e.g. crop yields, nutrient applications, tillage types) are only available at regional scale (county or state level). Therefore, a hierarchical data organization system (HDOS) (Figure 2) facilitates fusing geospatial data from multiple sources at different spatial resolutions, including climate, land use, soil, and topography, to derive homogeneous spatial modeling units (HSMU) at fine scale, while simultaneously allowing geo-referencing of crop management information from different sources to specific HSMUs (Figure 2). The HDOS is designed to be flexible to use data at different levels of detail. Using the conterminous U.S. as an example, the HDOS is illustrated in (Figure 3). Given this HDOS, the modeling results can be flexibly aggregated into several levels: county, state, and conterminous U.S. modeling units. The finest resolution is currently $\sim 60 \mathrm{~m}$, which is determined by the maximum resolution of the CDL and SSURGO data. The HSMU is determined by the unique combination of state, county, LCLU, soil, and hydrologic catalogue unit. Each HSMU has a unique ID and the associated attribute variables that allow preparing climate, land surface, and management parameters for input to the EPIC model. 


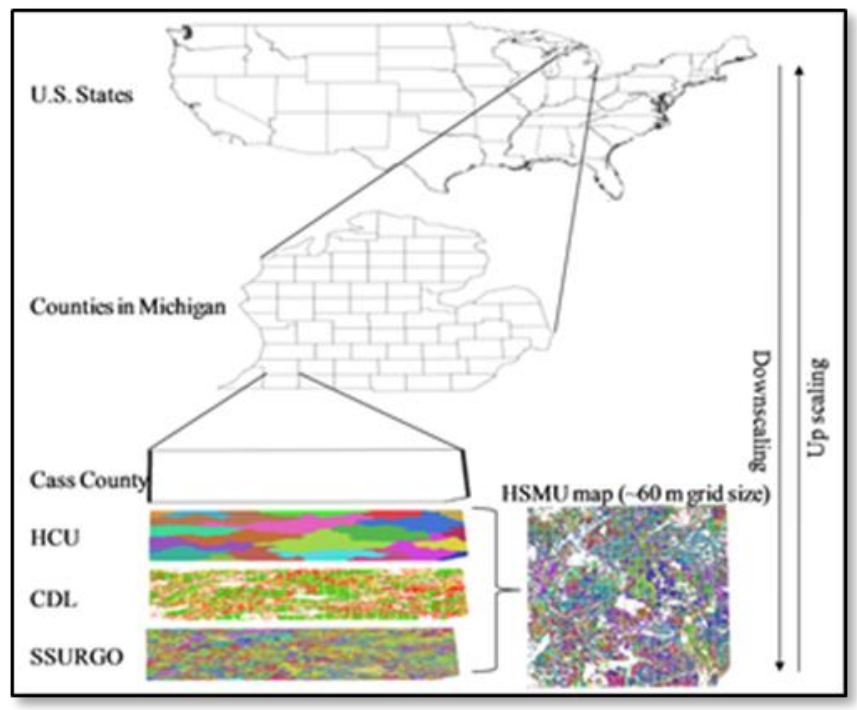

Figure 2. Illustration of the hierarchical and flexible downscaling and upscaling schemes in United States lands (Zhang et al., 2010).

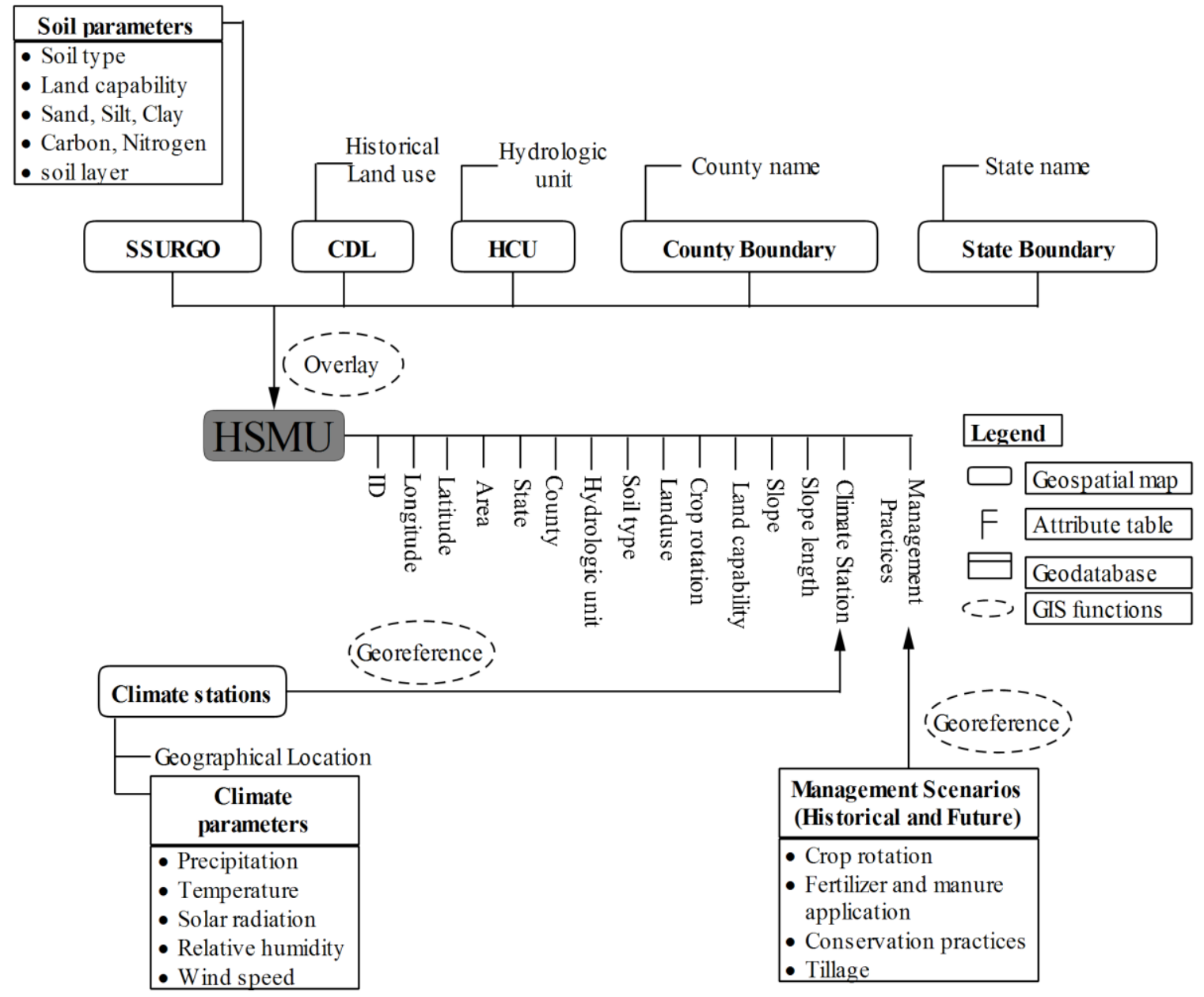

Figure 3. Diagram showing procedures to define HSMUs (Homogeneous Spatial Modeling Units). 
For each HSMU, EPIC simulates all of the land management scenarios and reports numerous variables related to productivity and environmental impacts for various biofuel crop production systems. These results are stored in three alternative formats to facilitate multi-platform data access: Microsoft Excel worksheets, Microsoft Access databases, and PostgreSQL databases. Internet based data transfer is also available by using PostgreSQL. These modeling results are linked to the HSMU map by using the unique ID field (Figure 3), which allows users to visualize the spatial distribution of the output variables.

\subsubsection{Site Validation}

EPIC has undergone intensive testing under diverse climate, soil, and management environments. Examples of validation results reported in the literature include those for water erosion and snowmelt runoff (Puurveen et al., 1997; Chung et al., 1999), crop yield (Roloff et al., 1998), climatic variability (Izaurralde et al., 1999; Legler et al., 1999), climate change (Easterling et al., 1996; Brown and Rosenberg, 1999; Izaurralde et al., 2003; Thomson et al., 2002), nutrient cycling (Cavero et al., 1998), tile drain flow and nitrate leaching (Chung et al., 2001), soil organic carbon (Izaurralde et al. 2006; Izaurralde et al. 2007). In this report, we focus mainly on evaluating EPIC for crop yield and carbon balance simulations.

\subsubsection{Native Prairie}

Site-scale simulations based on specific data were conducted to calibrate the EPIC model before applying it to the regional-scale simulations. Data from two Long-term Ecological Research (LTER) sites, at the Kellogg Biological Station (KBS) in Michigan and at Cedar Creek (CDR) in Minnesota, were used to parameterize EPIC and model aboveground net primary productivity (ANPP) of successional vegetation growing on former agricultural fields. Data included in the parameterization and initialization included historical weather, terrain characteristics, and soil properties. The treatments selected for the simulations were natural herbaceous vegetation or early successional (ES). The treatments were initiated in 1989 when agricultural management ceased and natural vegetation was allowed to re-establish. Spring burning was implemented in 1997 and whenever necessary thereafter to inhibit colonization of woody species.

The EPIC calibration with KBS LTER results was achieved by simulating the composition of the ES plant community with three species from the EPIC crop database (Poa pratensis, Phleum pratense, and Trifolium pratense). Spring burning with $80 \%$ efficiency was simulated in 1997, 2003, 2004, 2006, and 2008. Aboveground NPP was simulated under three different scenarios; one was left completely unmanaged (no harvest and no $\mathrm{N}$ addition), and the other two were simulated with fall harvest with $\mathrm{N}$ at 0 or $123 \mathrm{~kg} \mathrm{ha}^{-1} \mathrm{yr}^{-1}$. EPIC model runs were based on historical records of daily maximum and minimum air temperature and precipitation from the KBS LTER dataset (http://lter.kbs.msu.edu/datatables). Daily solar radiation, relative humidity, wind speed, and missing temperature and precipitation data were acquired from Gull Lake NWS weather station $\left(42^{\circ} 24^{\prime} \mathrm{N} 85^{\circ} 23^{\prime} \mathrm{W}\right)$ also at $\mathrm{KBS}$.

The EPIC simulations of ANPP for Cedar Creek, MN were conducted with data from the CDR LTER site. A 60-yr chronosequence experiment was simulated according to Zak et al. 
(1990). The chronosequence consisted of a series of 14 agricultural fields on Alfic and Typic Udipsamments (Soil Survey Staff, accessed August 2011) left unmanaged during periods ranging from one to 60 years. Both $\mathrm{C} 3$ and $\mathrm{C} 4$ species were present in the chronosequence fields. The chronosequence was simulated with an equal mix of generic $\mathrm{C} 3$ and $\mathrm{C} 4$ species from the EPIC crop database and driven by simulated daily weather generated from data of weather station at Rosemount, MN near CDR LTER station. Weather parameters were used to simulate ANPP during a 60-yr period intended to approximate environmental conditions for $1928-1987$.

\subsubsection{Corn, Soybean, and Winter Wheat}

As with the calibration of the EPIC model for native prairie, EPIC was parameterized for modeling corn, soybean, and winter wheat (Triticum aestivum L.) under both chisel and no-till management on existing agricultural land using data from the KBS LTER site near Kalamazoo, Michigan. These treatments were established in 1989 as corn/soybean rotations, with wheat added to the rotation in the fall of 1994. Using similar soil, terrain, and weather data as for the native prairie calibration (making sure to match to any differences in the real properties of these plots versus the native prairie plots), EPIC was calibrated by simulating the management practices indicated in the agricultural $\log$ (http://lter.kbs.msu.edu/datatables/150) for replicate 3 (R3) of treatments 1 and 2 (T1, T2) from 1989 to 2005. EPIC was calibrated on these sites for both yearly yield values and summarized by month and by year.

\subsubsection{Testing EPIC with Eddy Covariance Data}

To test the capability of EPIC to simulate ecosystem carbon balance, we obtained Net Ecosystem Exchange ${ }^{1}$ data from two eddy covariance experiments located at Mead, Nebraska ( $41^{\circ} 11^{\prime} \mathrm{N}, 96^{\circ} 26^{\prime} \mathrm{W}$ ) and Rosemount, Minnesota (44 42' N, 96 8' W) from the AmeriFlux network (http://public.ornl.gov/ameriflux/). At Mead, we simulated three treatments: two irrigated and one dryland. Here we only show results for a dryland no-till corn-soybean rotation (Figure). At Rosemount, we simulated two treatments: dryland no-till rye-soybean-corn rotation and dryland chisel-till continuous corn rotation.

\subsection{Regional Simulations}

\subsubsection{Simulation of Potential Biomass Supply and Environmental Impacts of Collecting Residue from Cultivated Lands in $\mathbf{3 0}$ states of US}

In order to simulate potential biomass supply from crop residues, we extracted from the SENGBEM national database all the EPIC input data needed to simulate a baseline scenario of crop production based primarily on three major crops (corn, soybean, and winter wheat), as grown in their current growing areas. Figure 4 shows the current distribution of corn acres from NASS in the conterminous U.S. Also shown are the borders of 12 states of the US Midwest that have been the focus of the GLBRC research program. Similarly, Figure 5 shows the soybean acres, which largely overlap with the corn acres in Figure 4. The major difference in growing area

\footnotetext{
${ }^{1}$ Net Ecosystem Exchange $=($ Plant Respiration + Heterotrophic Respiration $)-$ Gross Photosynthesis.
} 
between the two crops occurs in western Nebraska and western Kansas where field crops (primarily corn) are grown under irrigation. Winter wheat occupies its own area defined mainly by the Great Plains states, Montana and the Pacific Northwest (Figure 6). For illustration purposes, Figure 7 shows the irrigated area of the conterminous USA.

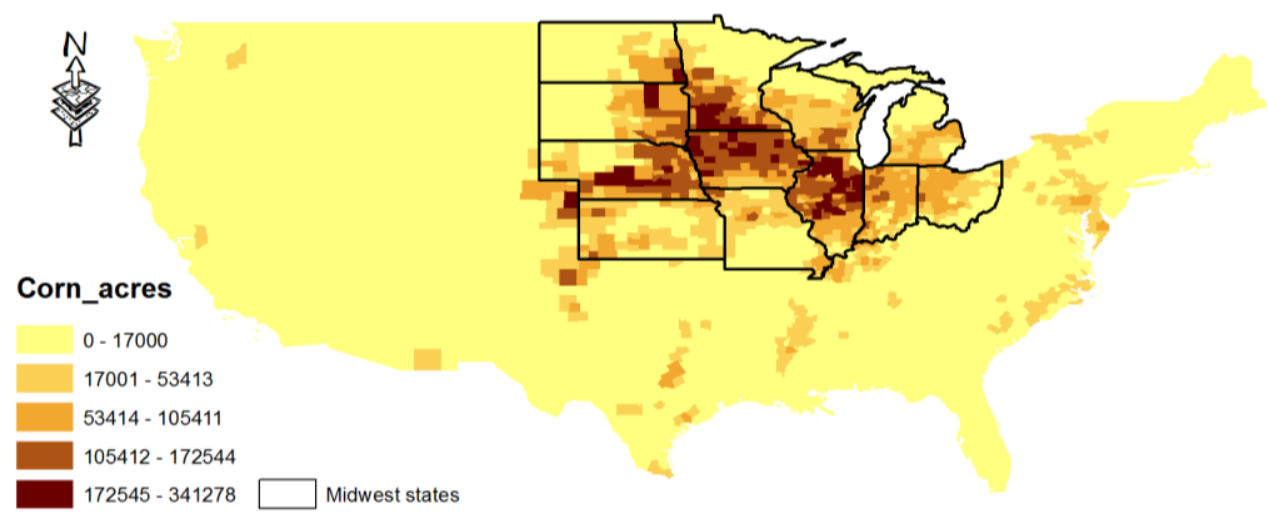

Figure 4. Corn acres across the conterminous USA

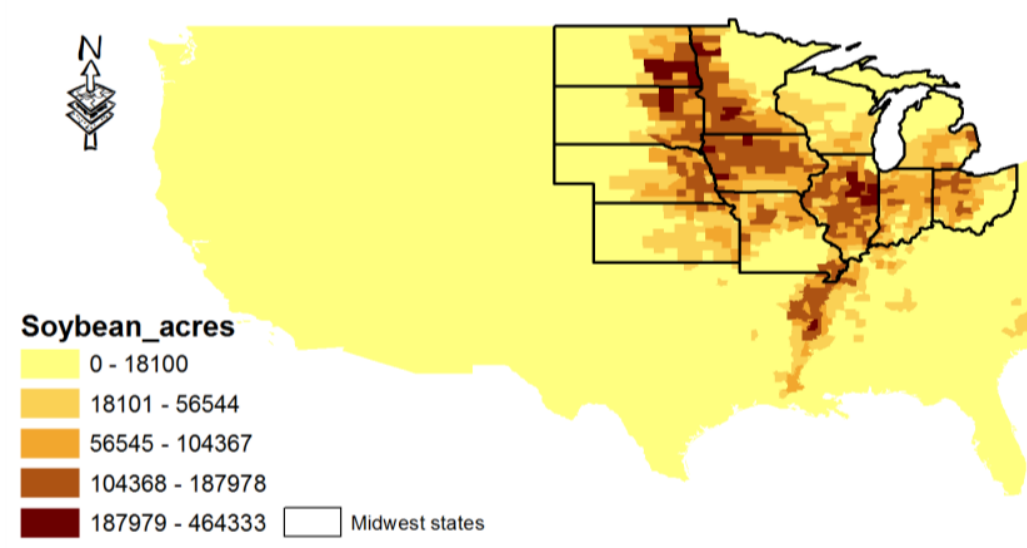

Figure 5. Soybean acres across the conterminous USA

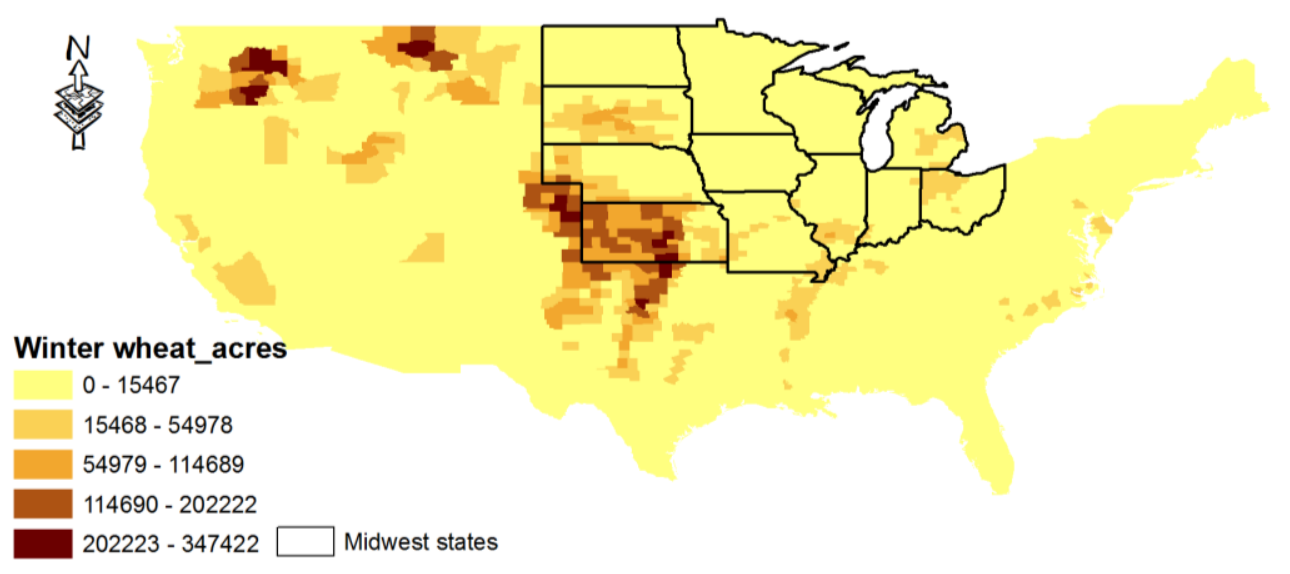

Figure 6. Wheat acres across the conterminous USA 


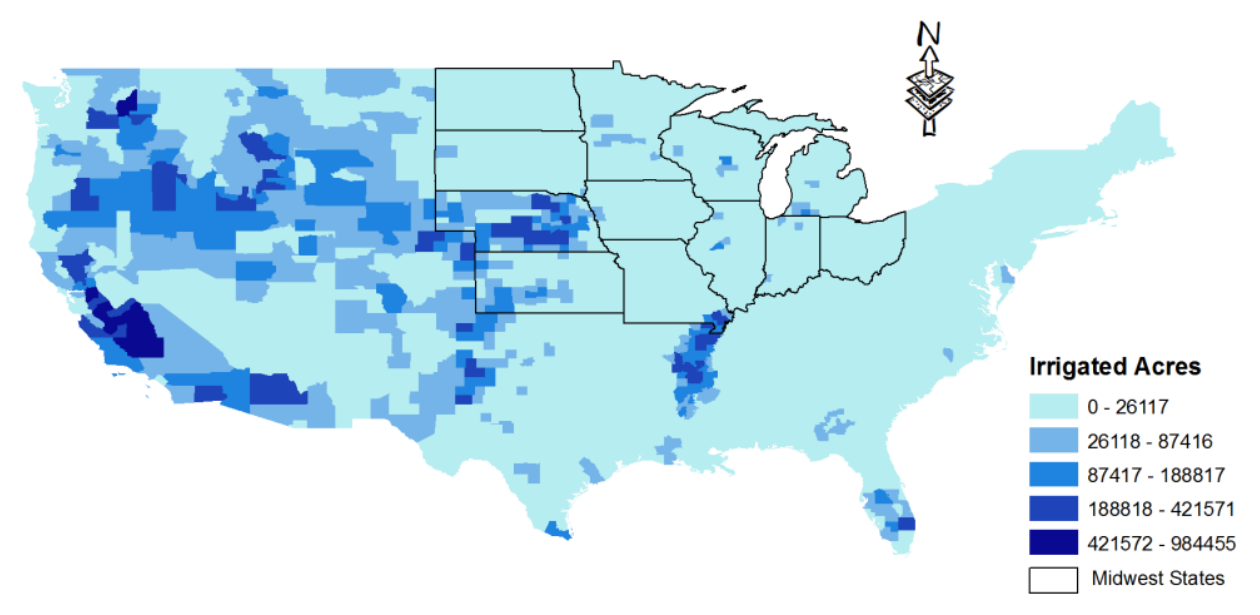

Figure 7. Irrigated acres of cropland across the conterminous USA (AgCensus, 2007).

Data from the SENGBEM database were used to establish the CDL-based corn- and wheatbased rotations across the 30 states (see Section 2.2). Fertilization and tillage information was derived as per the method outlined in Section 2.2. This was considered the baseline or historical scenario. The crop residue (alternative) treatment consisted in running all HSMUs and harvesting corn stover and wheat residue after grain harvest with an efficiency of $50 \%$.

\subsubsection{Simulation of Potential Cellulosic Feedstock Supply from Perennial Biomass Crops Grown on Marginal Lands}

Here we provide the methodology followed to estimate potential biomass production from marginal lands and for siting cellulosic ethanol biorefineries. We examine the hypothesis proposed by Tilman et al. (2009) that perennial plants grown on marginal lands can provide significant amounts of feedstock for cellulosic ethanol production while minimizing competition with food crops. Efficient use of these lands for bioenergy production can also help minimize the potential for direct and indirect land clearing associated with biofuel expansion, as well as the resultant creation of long-term carbon debt and biodiversity loss.

The SENGBEM national database described in Section 2.2 was used to simulate yields of perennial herbaceous species grown on marginal lands across the US Midwest study region. This region extends from North Dakota in the NW corner, south to Nebraska in the SW corner, east to Ohio in the SE corner, and up to Michigan in the NE corner. The Canada - USA border defines the northern border of the study region. A geospatial database containing soil, terrain, weather, land use/land cover and management data was used to obtain relevant parameters for running the EPIC model.

Three scenarios of feedstock supply based on perennial biomass crops grown on marginal lands were simulated: 1) switchgrass (Panicum virgatum L.) and 2) perennial herbaceous mixtures across the US Midwest, and 3) perennial herbaceous mixtures on Conservation Reserve Program (CRP) lands in Iowa. There were differences in their simulations in terms of their spatial domain and scope as explained in the next sub-sections (2.4.2.1 - 2.4.2.3). 


\subsubsection{Potential Biomass Production from Switchgrass on Marginal Agricultural Lands of the US Midwest}

Switchgrass simulations with EPIC were performed across all cultivated acres of the US Midwest. However, here we only report potential productivity of switchgrass when grown on marginal lands across cultivated acres of the US Midwest. Using CDL land cover data and soil property information from SSURGO, we selected marginal lands from the cultivated land base as those lands falling into Land Capability Classes IV - VII. For each HSMU of marginal land, we simulated switchgrass yields by the calibrated EPIC model (see Section 2.3.3.1 of this report) fertilized with $\mathrm{N}$ at $68 \mathrm{~kg} \mathrm{~N}^{-1} \mathrm{yr}^{-1}$.

\subsubsection{Simulation of Cellulosic Biomass Supply from Perennial Herbaceous Mixtures across Marginal Lands of the US Midwest}

The methodology used to simulate perennial herbaceous mixture was similar, in general, to that detailed in sub-section 2.4.2.1. However, special procedures and analyses were performed in order to contribute to a recently submitted manuscript on sustainable bioenergy production (Gelfand et al., submitted).

For these simulations, we followed the procedure described in Section 2.2 with the following details:

a) Land use and land cover. Cropland data layer (CDL) for 2008 and SSURGO map were combined to define LCLU and soil type at a spatial resolution of $60 \mathrm{~m}$ for the simulation domain. Federal lands, golf courses, parks, large-lot single-family housing units, and vegetation planted in developed settings for erosion control, recreation, or aesthetic purposes were excluded from the simulation domain.

b) Soils and marginal lands. Soil layer properties to run EPIC originated from the SSURGO database. Marginal lands were identified as rural lands falling into Land Capability Classes V-VII with slope gradients $<20 \%$ under non-forested vegetation. Special consideration was given to the Sandhills of Nebraska whose unique grass-stabilized sand dune topography distinguishes them from the surrounding prairies (Eggemeyer et al., 2006). The sand dunes can be hundreds of meters tall and several kilometers long. The inter-dune valleys have been the largest sources of hay for the cattle industry in Nebraska (Gosselin et al., 2006). To keep only the inter-dune valleys and exclude the fragile dune ridges and slopes from the analysis, the Topographic Position Index (TPI) algorithm available in ArcGIS (Tagil and Jenness, 2008) was used. The TPI is a classification scheme based on the difference in elevation values between a cell in a DEM raster and its neighbors. The extent to which a cell is higher or lower as compared to its neighbors, combined with its slope, can be used to assign it a landform classification like valley, ridge etc. Removing the dune ridges and slopes from the analysis reduced the area available for consideration as marginal lands by more than 200,000 ha. The inter-dune valleys falling under LCC V-VII and with slope gradients $<20 \%$ were then used for further analysis using EPIC model. 
The available area of marginal lands varied considerably by state (Figure 8). Overall, available area of marginal lands varied from $<100,000$ ha in Ohio (1\% of total land) to more than 6.4 million ha in Nebraska (30\% of total land).

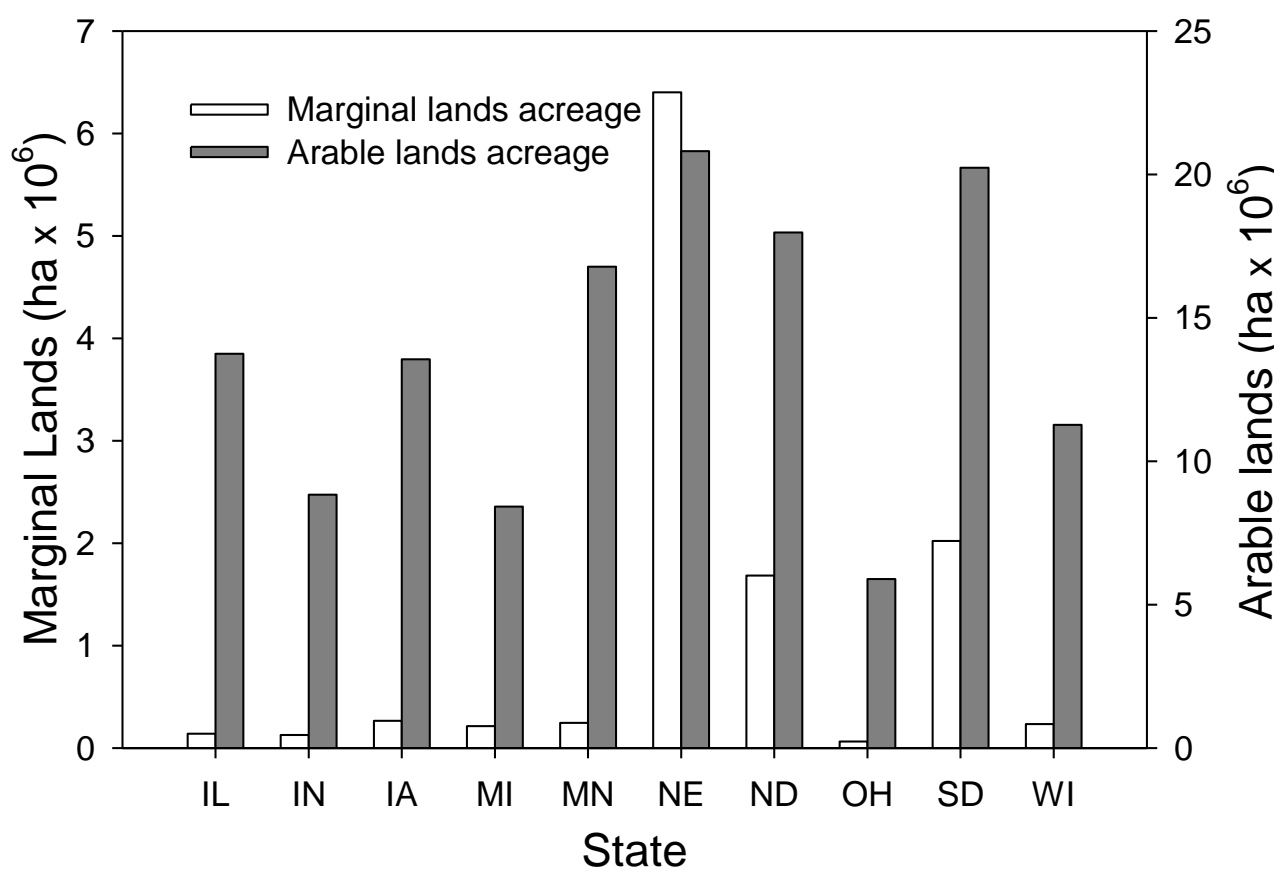

Figure 8. Marginal lands area $\left(\times 10^{6}\right.$ ha) in 10-states of the US Midwest region, as modeled by EPIC (left Y axis) and arable land area (right Y axis) from Cropland Data Layer of 2008.

For each grid of marginal land, we simulated ANPP by the calibrated EPIC model (see Section 2.3.3.1 of this report) under three levels of $\mathrm{N}$ fertilization: 0,68 , and $123 \mathrm{~kg} \mathrm{~N} \mathrm{ha}^{-1} \mathrm{yr}^{-1}$. The ANPP values obtained from EPIC were used to identify the location of potential biorefineries that could process the resulting cellulosic feedstock. Only results from the $68 \mathrm{~kg} \mathrm{~N} \mathrm{ha}^{-1} \mathrm{yr}^{-1}$ scenario have been used in this analysis. The siting of a potential biorefinery was limited to areas where potential feedstock derived from such fields could provide at least $768 \mathrm{Gg} \mathrm{yr}^{-1}$ of cellulosic biomass from within an economically feasible transportation distance of $80 \mathrm{~km}$. To accomplish this, a moving window algorithm was implemented over the study region. Subsequently, nonoverlapping circles with the highest biomass yields were selected as potential biorefinery locations. We used Yield $\times 0.06 \mathrm{~km} \times 0.06 \mathrm{~km} \times 380.0 \mathrm{~L} \mathrm{Mg}^{-1} \times 100=$ Yield $\times 136.8$

Equation 1 to convert biomass yields into liters of ethanol:

$$
\text { Yield } \times 0.06 \mathrm{~km} \times 0.06 \mathrm{~km} \times 380.0 \mathrm{~L} \mathrm{Mg}^{-1} \times 100=\text { Yield } \times 136.8 \quad \text { Equation } 1
$$

Where, Yield $\left(\mathrm{Mg} \mathrm{ha}^{-1}\right)$ is biomass production, $0.06 \mathrm{~km} \times 0.06 \mathrm{~km}$ is the cell size of the model, $380.0 \mathrm{~L} \mathrm{Mg}^{-1}$ is the conversion factor for converting cellulosic biomass to ethanol, and 100 is number of hectares in $1 \mathrm{~km}^{2}$. 


\subsubsection{Simulation of Potential Cellulosic Biomass Supply from CRP lands in lowa}

Recent studies suggest that cellulosic feedstocks may be grown on Conservation Reserve Program (CRP) land to help meet targeted biofuel volumes, without direct competition with food supply. However, CRP lands provide environmental benefits, particularly reducing sediment and nutrient loads to waterways and sequestering carbon in the soil. Placing CRP land back into production can have a much larger per-area impact on these environmental factors than agricultural lands currently in production. Here we estimated the biomass production capacity of switchgrass and a perennial mixture (Kentucky bluegrass, timothy, and red clover) on CRP land in Iowa, and estimate the impacts on erosion, soil $\mathrm{C}$, soil nitrogen $(\mathrm{N})$ and potential fluxes to the atmosphere and water bodies.

Based on a Non-Disclosure Agreement between USDA Farm Service Agency (FSA) and PNNL, we obtained from USDA FSA the CRP database to execute site-specific simulations of CRP land use conversions to biofuel production using perennial species, as described above. Of the different CRP types, we selected 3 types of CRP lands in Iowa that are currently under grass cover to simulate with EPIC: a) CP1 new introduced grasses and legumes, 2) CP2 new native grasses, and 3) CP10 existing grasses and legumes.

\subsection{Results and Discussion}

The results reported herein address the four specific objectives described in Section 1.2:

1) To develop a spatially explicit national geodatabase to conduct biofuel simulation studies

2) To conduct simulation studies to estimate biomass productivity of various biomass feedstocks (crop residue, perennial species) and associated environmental impacts

3) To analyze the siting of biorefineries based on cellulosic feedstock collection from marginal lands

4) To simulate perennial biomass feedstocks grown on marginal lands

\subsection{Features of the National Geodatabase to Simulate Biofuel Production}

The National Geodatabase of Contemporary Land Cover and Use in the Conterminous USA is shown in Figure 9. The map is presented in highly aggregated form representing only some predominant crop rotations (e.g. corn-based rotation, winter wheat - fallow) and land covers (e.g. forests, grasslands, urban). This level of aggregation and abstraction is necessary in order to visualize some of the predominant land uses and land covers. However, the map / database retains all the richness of the high-resolution data from which the map was built. In other words, it is possible to zoom in to a particular $60 \mathrm{~m}$ x $60 \mathrm{~m}$ field and see the details of its topography, soil properties, and LCLU. Conversely, simulations conducted at the HSMU scale can be scaled-up to watershed, county, state, and even national level without losing any information. 


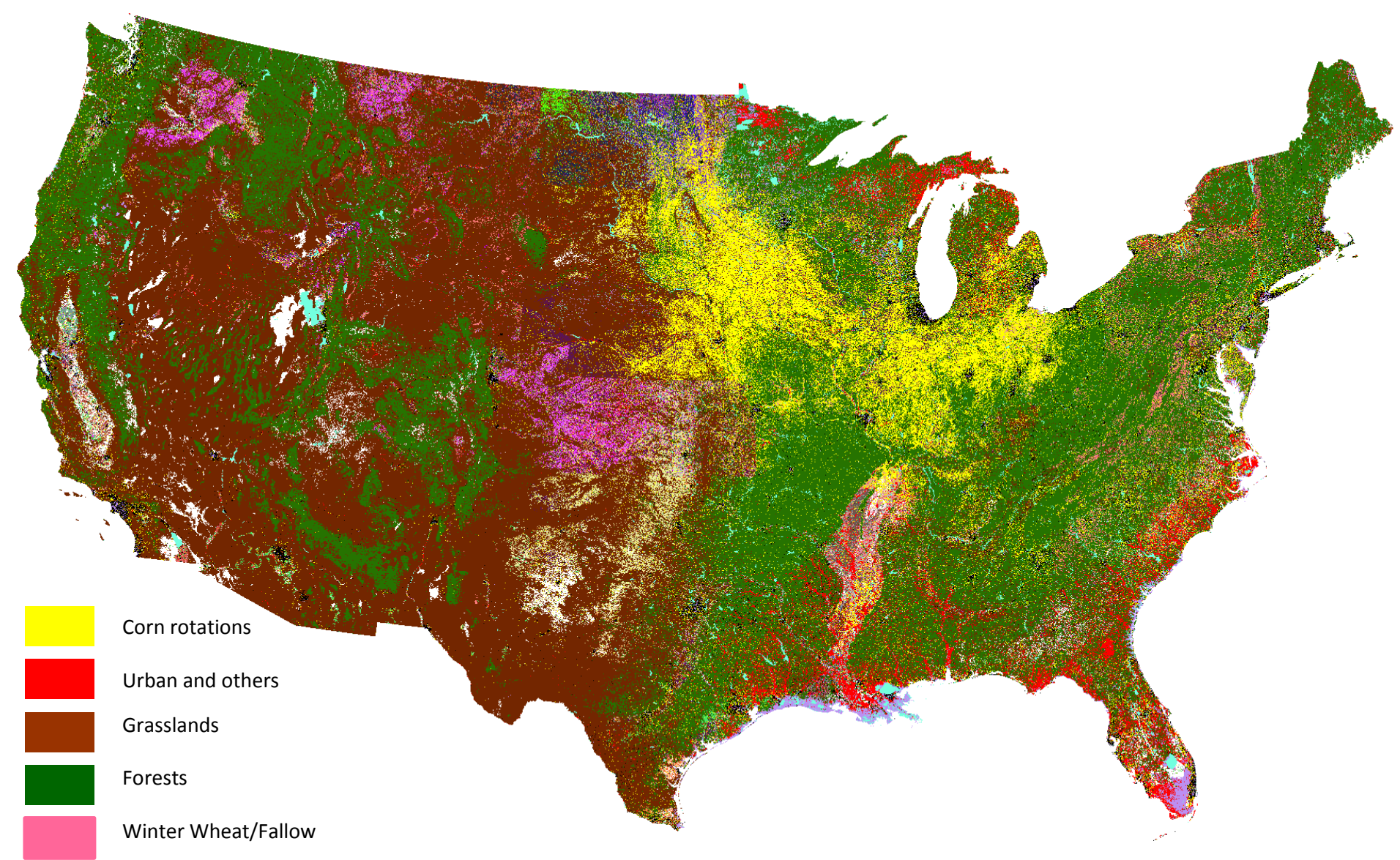

Figure 9. National Geodatabase of Contemporary Land Cover and Use in the Conterminous USA. 
The level of detail included in this database allows a user to exclude a number of features not needed in the aggregation such as protected, recreational, urban, suburban, and commercial areas.

The crop rotation (land use) component is a unique feature of the database. Information on the contemporary distribution of field crops on a given field and their change in sequence over time (i.e. crop rotation) is crucial for the understanding of land issues such as soil quality, carbon management, agricultural emissions of greenhouse gases, etc. As such, we believe the database presented represents a major advance for increasing the accuracy of environmental modeling and, in particular, for biofuel modeling.

\subsection{Site Simulations}

\subsubsection{Native Prairie}

Aboveground NPP simulated by EPIC during $2000-2008$ averaged $6.0 \pm 1.1 \mathrm{Mg} \mathrm{ha}^{-1} \mathrm{yr}^{-1}$ for the scenario without biomass harvest or fertilization, which is similar to the observed average of $5.98 \pm 0.44 \mathrm{Mg} \mathrm{ha}^{-1}$. Similarly, simulated ANPP for the scenario with harvest and fertilization was very close to field-based estimation, $9.6 \pm 0.8$ vs. $8.79 \pm 0.64 \mathrm{Mg} \mathrm{ha}^{-1}$.

Direct comparisons of biomass productivity results were not possible for the CDR data because the simulations were not time specific. Simulated standing aboveground biomass during the JulyAugust period averaged $5.13 \pm 1.13 \mathrm{Mg} \mathrm{ha}^{-1}$ during the first three years. In comparison, observed yields were $5.09 \mathrm{Mg} \mathrm{ha}^{-1}$ in the 1 -yr old plot and $2.96 \mathrm{Mg} \mathrm{ha}^{-1}$ in the 3-yr old field. Simulated biomass during the last three years of the simulation averaged $7.67 \pm 1.27 \mathrm{Mg} \mathrm{ha}^{-1}$, while the observed value was $7.83 \mathrm{Mg} \mathrm{ha}^{-1}$ in the 60 -yr old field. While EPIC failed to capture the decrease in plant productivity observed during the first years of the chronosequence, it did capture the increase in productivity toward the end of the simulation period. Similar to observations, simulated annual biomass productivity correlated moderately well with $\mathrm{N}$ mineralization and soil $\mathrm{N}$.

Overall, EPIC appeared to capture adequately the observed plant productivity patterns from both KBS and CDR LTER sites under different environmental constraints and management scenarios. Acceptable agreements between EPIC simulations and observed data were reported also by Izaurralde et al. (2006) in simulations of the effects of unmanaged grasses on soil $\mathrm{C}$ accrual on marginal lands in Nebraska, Kansas, and Texas. These results have provided further justification to use EPIC for largescale simulations.

\subsubsection{Corn, Soybean, Winter Wheat}

Corn, soybean, and wheat are major crops in the US Midwest accounting for $>80 \%,>80 \%$, and $>50 \%$ of the total USA production, respectively. Corn stover and wheat residues are two of the most readily available sources of crop residue to start supplying a nascent cellulosic biofuel industry. Thus, the evaluation of EPIC for crop yield prediction has focused on these three major crops. As discussed above, we have obtained detailed management data (planting, tillage, fertilization, and harvesting) for the T1R3 and T2R3 plots at the Kellogg Biological Station 
(KBS, http://lter.kbs.msu.edu/datatables). T1 is a chisel-tilled corn-soybean-wheat rotation, while $\mathrm{T} 2$ is no-till corn/soybean/wheat. R3 represents replicate 3 under either treatment.

Overall, the annual variability of crop yields is well captured under these two treatments (Figure 10), as indicated by the high $\mathrm{R}^{2}$ values in the comparisons of simulated vs. observed data. The percentage of bias of the simulated multi-year average crop yields is less than $20 \%$ for all three crops. In addition, the EPIC model adequately captures the effect of different management practices (conventional till vs. no-till) on long-term crop yields (Figure 11), which has significant implications for the applicability of using EPIC to simulate long-term biofuel crop productivity under different management scenarios.
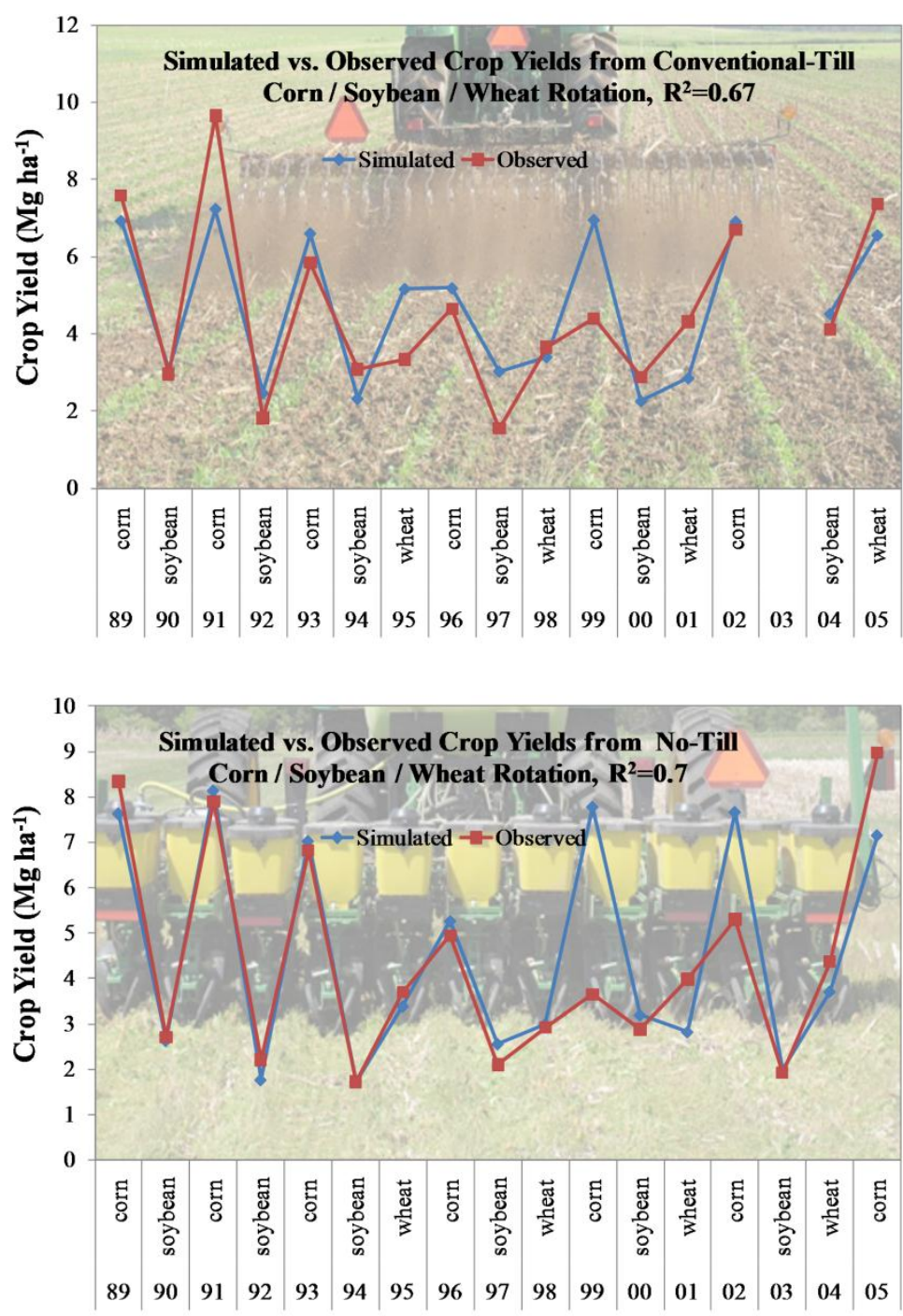

Figure 10. Annual crop yields of corn, soybean, and winter wheat on two contrasting plots. 

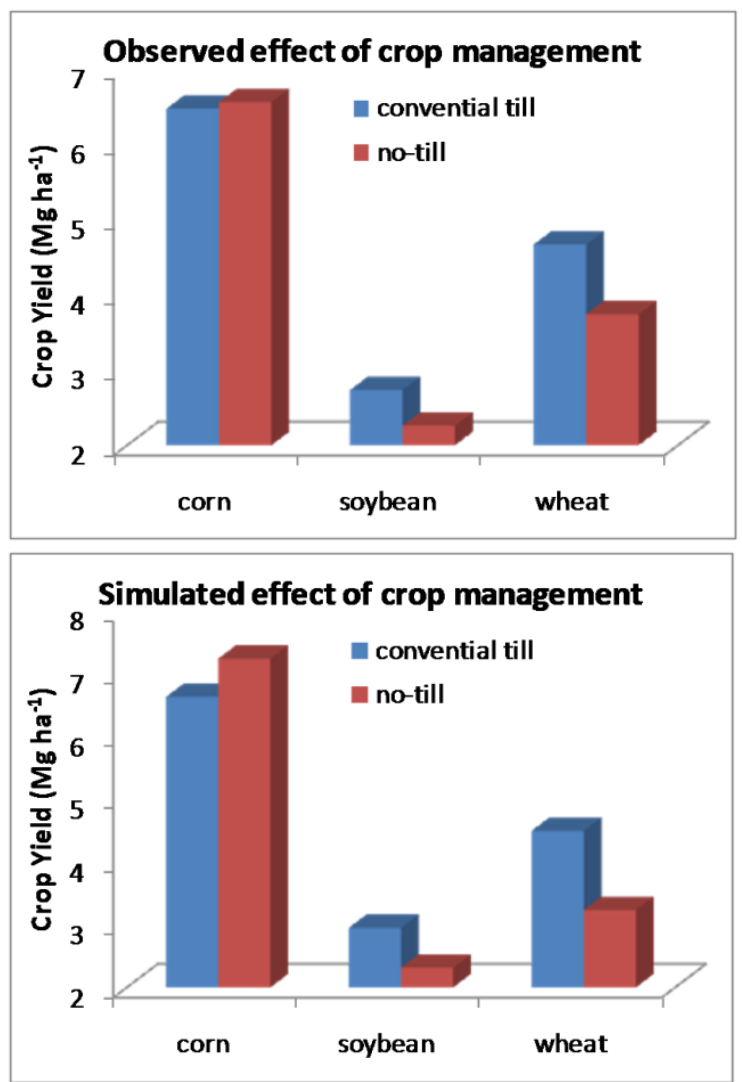

Figure 11. Simulated and observed long-term (1989-2005) impact of crop management practices on crop yields.

\subsubsection{Carbon balance}

Simulation results show that EPIC can capture well the observed land-atmosphere $\mathrm{CO}_{2}$ exchange in the three experiments (Figure 12). During the growing season, Net Ecosystem Exchange (NEE) values become negative; i.e., carbon is being drawn from the atmosphere into the terrestrial ecosystem. The model captures well the growing season trends as indicated by the observed and simulated trends in NEE under different cropping systems. The $\mathrm{R}^{2}$ of simulated and observed daily $\mathrm{CO}_{2}$ fluxes is high for the corn-soybean rotation both at Mead $\left(\mathrm{R}^{2}=0.75\right)$ and Rosemount $\left(R^{2}=0.78\right)$. However, the most complex rotation at Rosemount that included a rye cover crop in winter (corn-rye-soybean) has a lower $\mathrm{R}$-squared $\left(\mathrm{R}^{2}=0.51\right)$ than the other two rotations. 

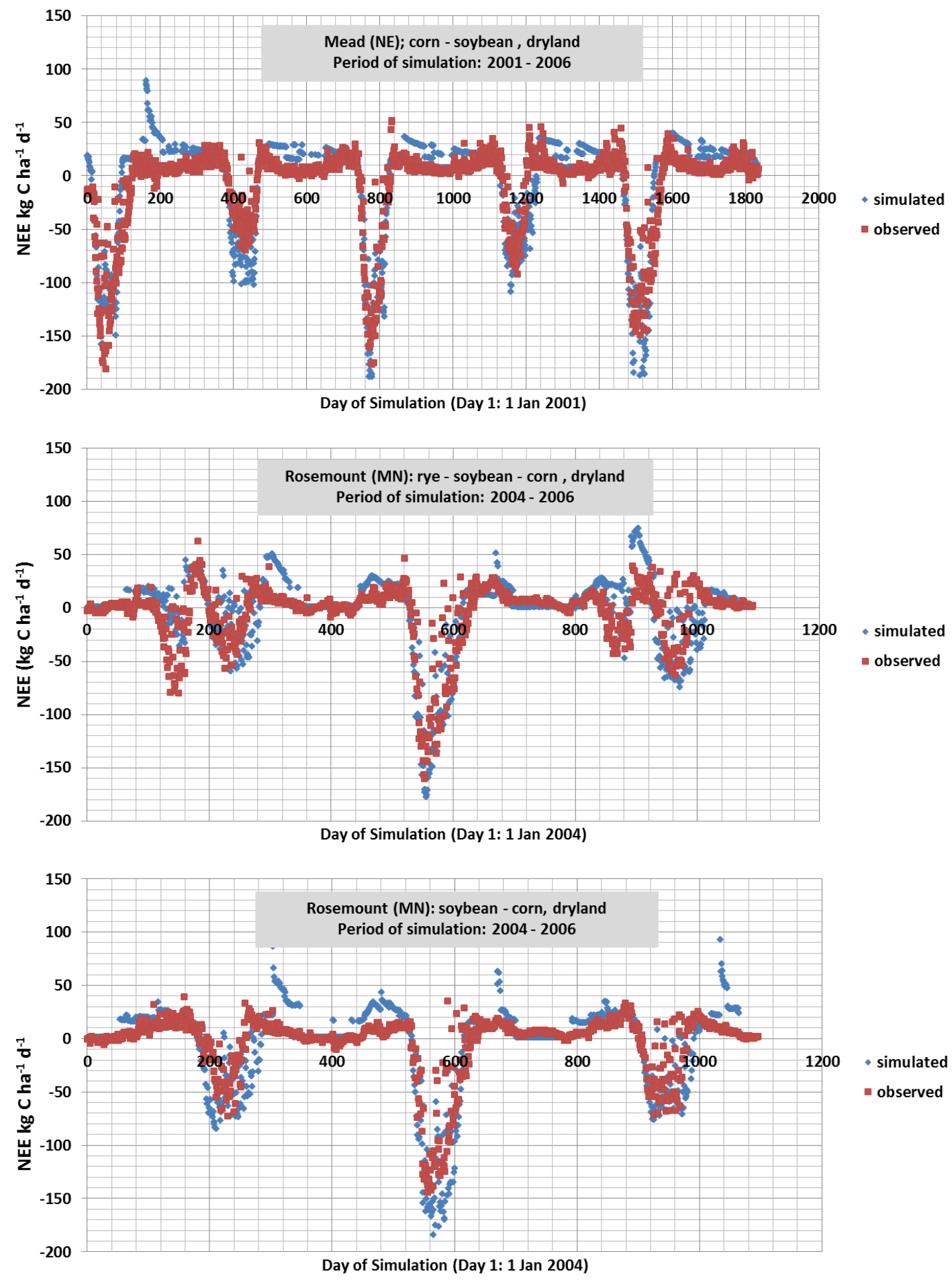

Figure 12. Simulated and observed NEE under three contrasting cropping systems. 


\subsection{Regional Simulations}

We executed EPIC on 2 million HSMUs over 30 states from 1979 to 2008. The period from 1979-1999 was used as spin up runs to initialize soil parameters such as soil organic carbon (SOC) and nitrogen. For each county, we calculated area-weighted simulated crop yield averages over 2000-2008 and used county-scale crop observed yield data averaged over the same period to evaluate the EPIC simulations.

Overall, EPIC can explain more than $60 \%$ percent of the variance of NASS-reported crop yield of corn, soybean, and winter wheat across the 30 states (Figure 13). Linear regression analysis of observed vs. simulated yield calculates a slope of 0.92 is close to 1.0, indicating a low bias of simulated crop yields over the 30 state region. However, it is worth noting that EPIC substantially underestimates corn yields in some counties, as exemplified by a group of points under the linear trend line and above the segment of 6-12 $\mathrm{Mg} \mathrm{ha}^{-1} \mathrm{yr}^{-1}$ on the $\mathrm{x}$-axis. Further examination shows that counties in Kansas, Nebraska, Texas and Alabama contribute to most of these points. As illustrated in Figure 7, there are significant amount of irrigated cropland in these three states. Therefore, not including crop irrigation operations in the EPIC simulations is one major factor leading to the underestimation of corn yields in these states.

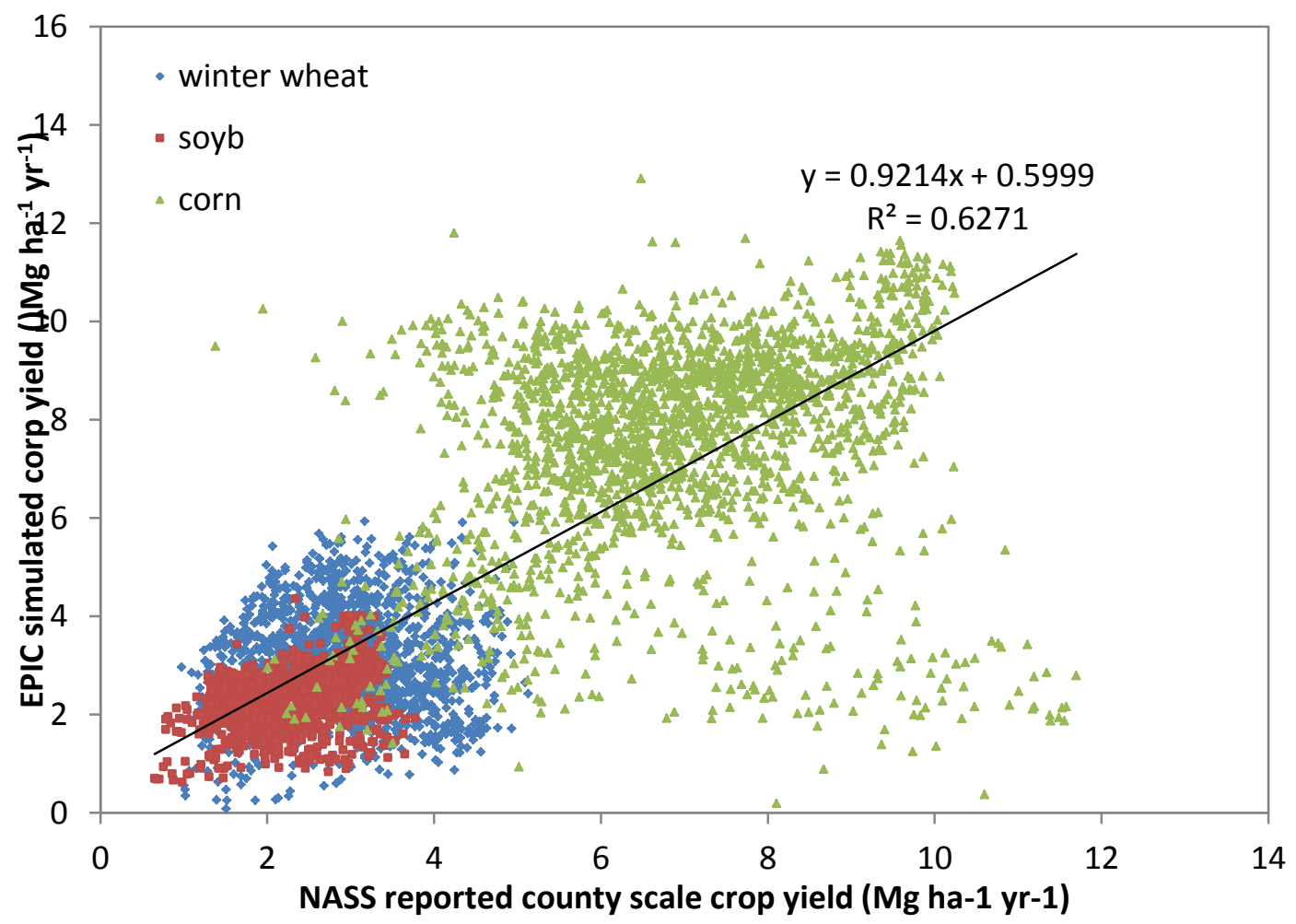

Figure 13. Comparison between EPIC-simulated and NASS-reported county level crop yields.

EPIC-simulated corn yield map (Figure 14) captures the high yields of corn in the Corn Belt, including Iowa and Illinois, reported by NASS (Figure 15). However, EPIC significantly underestimates corn yields in Nebraska, Southwest Kansas, and Northwest Texas due to the missing reliable irrigation management information in these regions. Further comparison between the spatial 
patterns of EPIC-simulated and NASS-reported corn yields at county level demonstrates that simulated and reported values do not match well in Montana and Pennsylvania, either. The discrepancy at county scale, to some extent, can be explained by the lack of accurate spatially explicit data on species variety and crop management data such as planting and harvesting dates, fertilizer levels, and tillage intensity. For example, we use uniform fertilizer application data at state level. However, actual application rates may show high spatial variability across areas within one state. Therefore, we do not list bias of simulated corn yields at county scale; instead, state-level bias is listed in Table 1 to show the uncertainty of EPIC simulations. For most states, EPIC simulations exhibit no more than $20 \%$ bias, except for Alabama, Montana, Nebraska, North Carolina, South Carolina, and Texas. Less corn is planted in Alabama, Montana, North Carolina, South Carolina, and Texas than in the Midwest. Thus, the relatively large bias in these states does affect the total production bias of corn simulations over the 29 states.

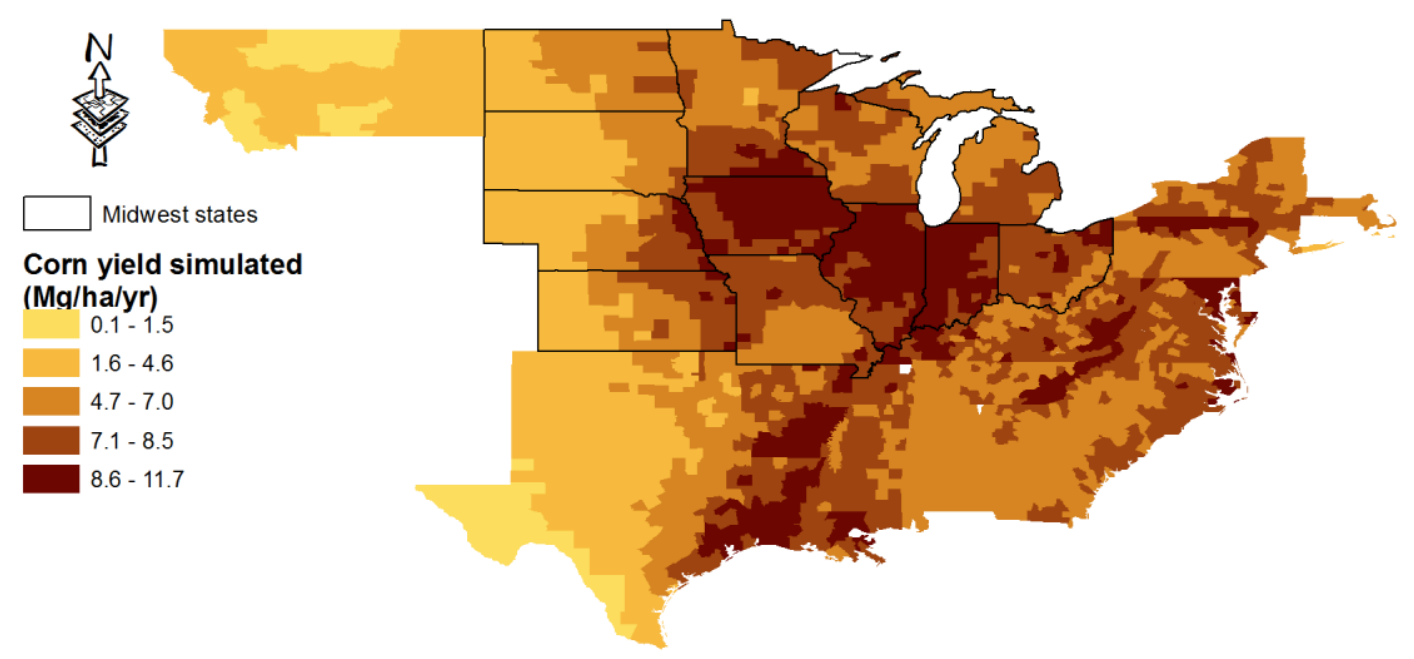

Figure 14. EPIC-simulated (dry) corn yields simulated at HSMU scale and aggregated to county scale.

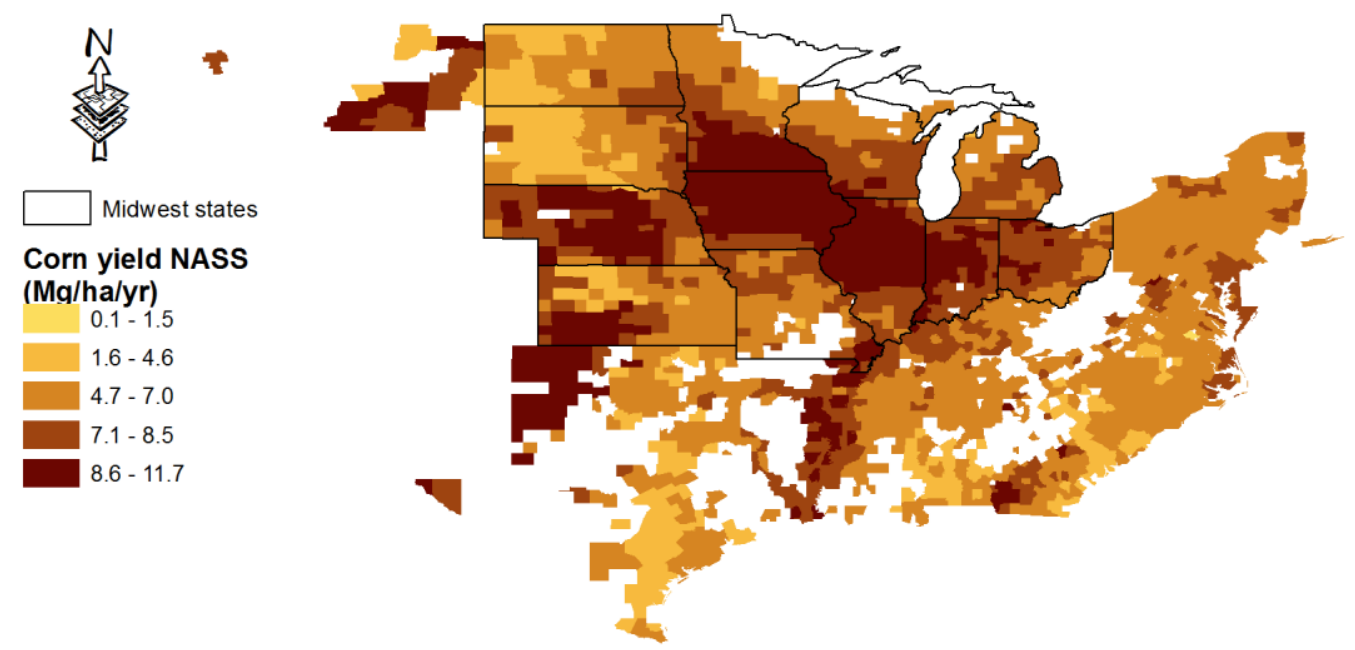

Figure 15. County (dry) corn yields reported by NASS. 
Table 1. Percentage of Bias of EPIC-simulated corn yield across 29 states.

\begin{tabular}{cccccccc}
\hline State & NASS & EPIC & PBIAS* & State & NASS & EPIC & PBIAS \\
\hline Alabama & 4.92 & 6.51 & $32.37 \%$ & Nebraska & 8.23 & 5.96 & $-27.62 \%$ \\
Arkansas & 8.08 & 8.03 & $-0.58 \%$ & New York & 6.47 & 6.89 & $6.55 \%$ \\
Georgia & 6.43 & 6.66 & $3.53 \%$ & North Carolina & 5.79 & 7.59 & $30.98 \%$ \\
Illinois & 8.70 & 8.92 & $2.52 \%$ & North Dakota & 5.06 & 5.23 & $3.40 \%$ \\
Indiana & 8.42 & 9.04 & $7.32 \%$ & Ohio & 7.58 & 7.75 & $2.27 \%$ \\
Iowa & 9.21 & 9.48 & $2.87 \%$ & Oklahoma & 5.63 & 4.86 & $-13.67 \%$ \\
Kansas & 6.66 & 5.94 & $-10.69 \%$ & Pennsylvania & 6.29 & 6.48 & $3.03 \%$ \\
Kentucky & 6.84 & 7.33 & $7.14 \%$ & South Carolina & 4.61 & 7.03 & $52.57 \%$ \\
Louisiana & 7.45 & 8.57 & $15.03 \%$ & South Dakota & 5.43 & 4.48 & $-17.57 \%$ \\
Maryland & 6.95 & 7.43 & $6.92 \%$ & Tennessee & 6.46 & 6.77 & $4.80 \%$ \\
Michigan & 6.68 & 7.02 & $4.97 \%$ & Texas & 5.94 & 3.88 & $-34.66 \%$ \\
Minnesota & 7.90 & 7.25 & $-8.23 \%$ & Virginia & 5.98 & 6.96 & $16.36 \%$ \\
Mississippi & 6.51 & 7.49 & $15.21 \%$ & West Virginia & 7.02 & 6.56 & $-6.45 \%$ \\
Missouri & 7.02 & 7.38 & $5.17 \%$ & Wisconsin & 7.29 & 7.03 & $-3.59 \%$ \\
Montana & 7.23 & 3.01 & $-58.36 \%$ & & & & \\
\hline *PBIAS is calculated as (EPIC simulated - NASS reported)/NASS reported × 100\%. & & &
\end{tabular}

In the case of soybean simulations, EPIC also captures well the high yield region in the Corn Belt as shown in Figure 16 and Figure 17. Similar to the corn simulations, EPIC significantly underestimates yields of soybean in Nebraska, Kansas, and Texas due to our omission of irrigation in these states. At state level, EPIC-simulated soybean yields fall within $20 \%$ bias, except Alabama, Nebraska, North Carolina, and South Carolina (Table 2). Overall, EPIC reproduces well both the spatial pattern and yield magnitude of soybean in the US Midwest region, the major production area of soybean. Further work is needed to improve the accuracy of simulated soybean yields with EPIC in the four aforementioned states.

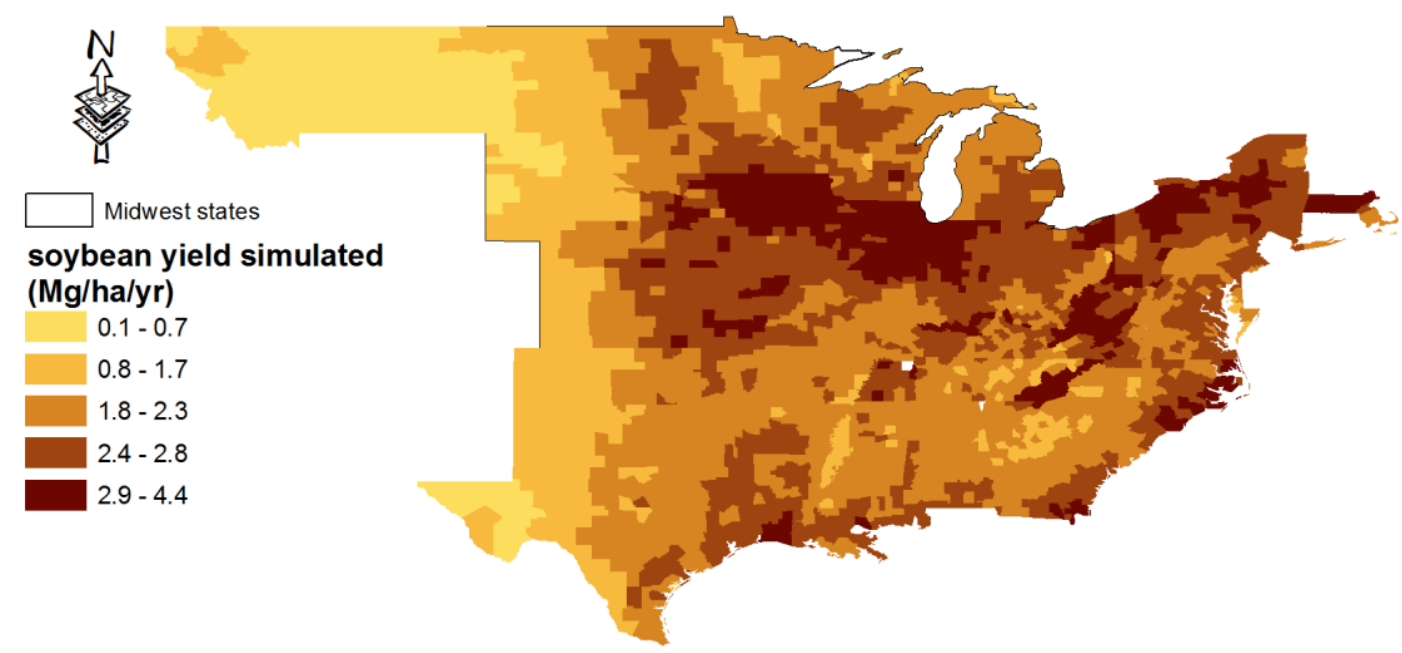

Figure 16. EPIC simulated (dry) soybean yields simulated at HSMU scale and aggregated at county scale. 

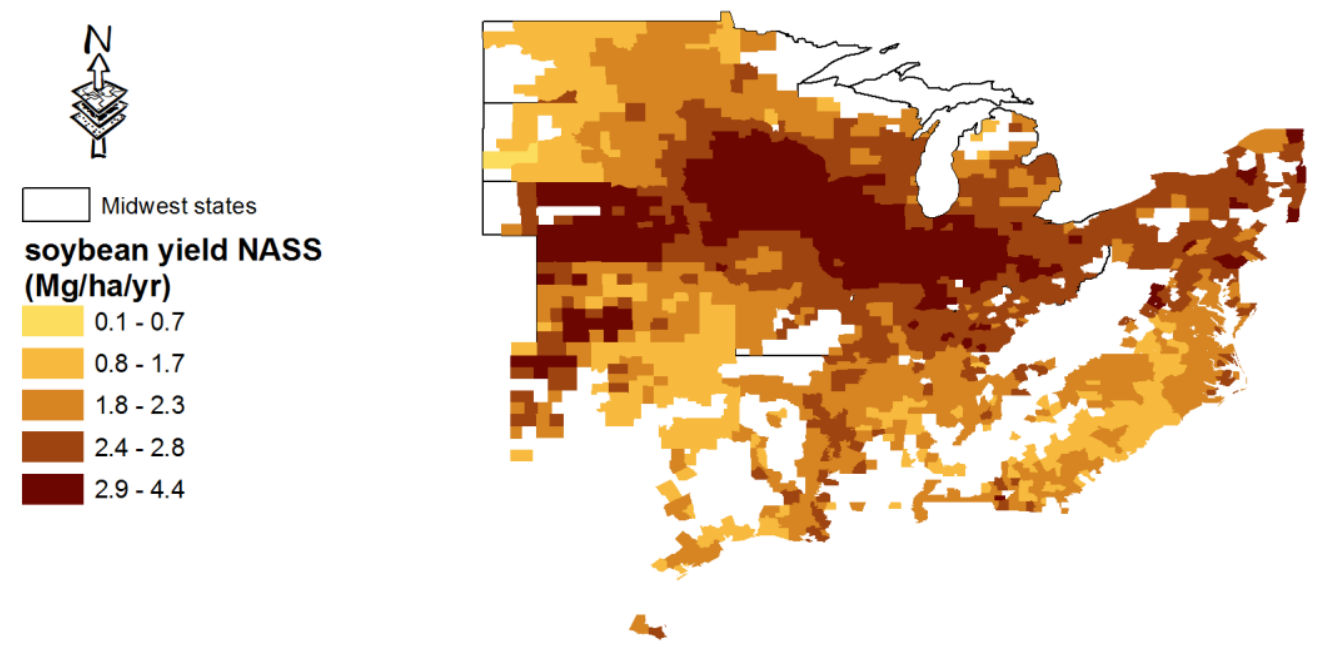

Figure 17. County (dry) soybean yields reported by NASS.

Table 2. Percentage of Bias of EPIC simulated soybean yield across 28 states

\begin{tabular}{cccccccc}
\hline State & NASS & EPIC & PBIAS & State & NASS & EPIC & PBIAS \\
\hline Alabama & 1.77 & 2.71 & $52.53 \%$ & Nebraska & 2.94 & 2.21 & $-24.97 \%$ \\
Arkansas & 2.11 & 2.07 & $-2.13 \%$ & New York & 2.51 & 2.49 & $-0.93 \%$ \\
Georgia & 1.78 & 2.03 & $14.02 \%$ & North Carolina & 1.91 & 2.54 & $32.74 \%$ \\
Illinois & 2.83 & 2.64 & $-6.56 \%$ & North Dakota & 1.73 & 1.72 & $-0.81 \%$ \\
Indiana & 2.93 & 2.73 & $-6.80 \%$ & Ohio & 2.65 & 2.48 & $-6.46 \%$ \\
Iowa & 2.99 & 3.09 & $3.54 \%$ & Oklahoma & 1.51 & 2.05 & $35.93 \%$ \\
Kansas & 2.12 & 2.17 & $2.35 \%$ & Pennsylvania & 2.47 & 2.33 & $-5.75 \%$ \\
Kentucky & 2.52 & 2.34 & $-7.00 \%$ & South Carolina & 1.57 & 2.22 & $41.36 \%$ \\
Louisiana & 2.04 & 2.41 & $18.54 \%$ & South Dakota & 1.84 & 1.68 & $-8.70 \%$ \\
Maryland & 2.25 & 2.54 & $12.80 \%$ & Tennessee & 2.15 & 2.08 & $-3.33 \%$ \\
Michigan & 2.20 & 2.29 & $3.73 \%$ & Texas & 1.94 & 1.75 & $-9.89 \%$ \\
Minnesota & 2.43 & 2.20 & $-9.43 \%$ & Virginia & 2.08 & 2.29 & $10.29 \%$ \\
Mississippi & 1.99 & 2.08 & $4.85 \%$ & West Virginia & 2.82 & 2.30 & $-18.36 \%$ \\
Missouri & 2.32 & 2.47 & $6.09 \%$ & Wisconsin & 2.38 & 2.26 & $-5.09 \%$ \\
\hline
\end{tabular}

The accuracy of CDL for identifying winter wheat is much less that for corn and soybean (Appendix I). For most states, accuracy of CDL for corn and soybean areas is higher than $80 \%$, while that for winter wheat is less than $80 \%$. In addition to the lack of accurate crop management data, the errors associated with CDL will lead to misidentification of soils for winter wheat modeling and larger biases in winter wheat simulations. Figure 18 shows that spatial patterns of EPIC-simulated and NASS-reported winter wheat yield (Figure 19) do not match well. For example, EPIC simulates substantially lower yields than reported in Indiana and Ohio but yields much higher than reported in Oklahoma and Kansas. Despite the failure in reproducing accurately the observed spatial variations, the biases of the EPIC simulations are less than $20 \%$ for 21 of the 29 states ( 
Table 3). However, the high bias in Kansas, which has a large area of winter wheat, may lead to significant uncertainty in the analysis of biofuel feedstocks supply from wheat residue.

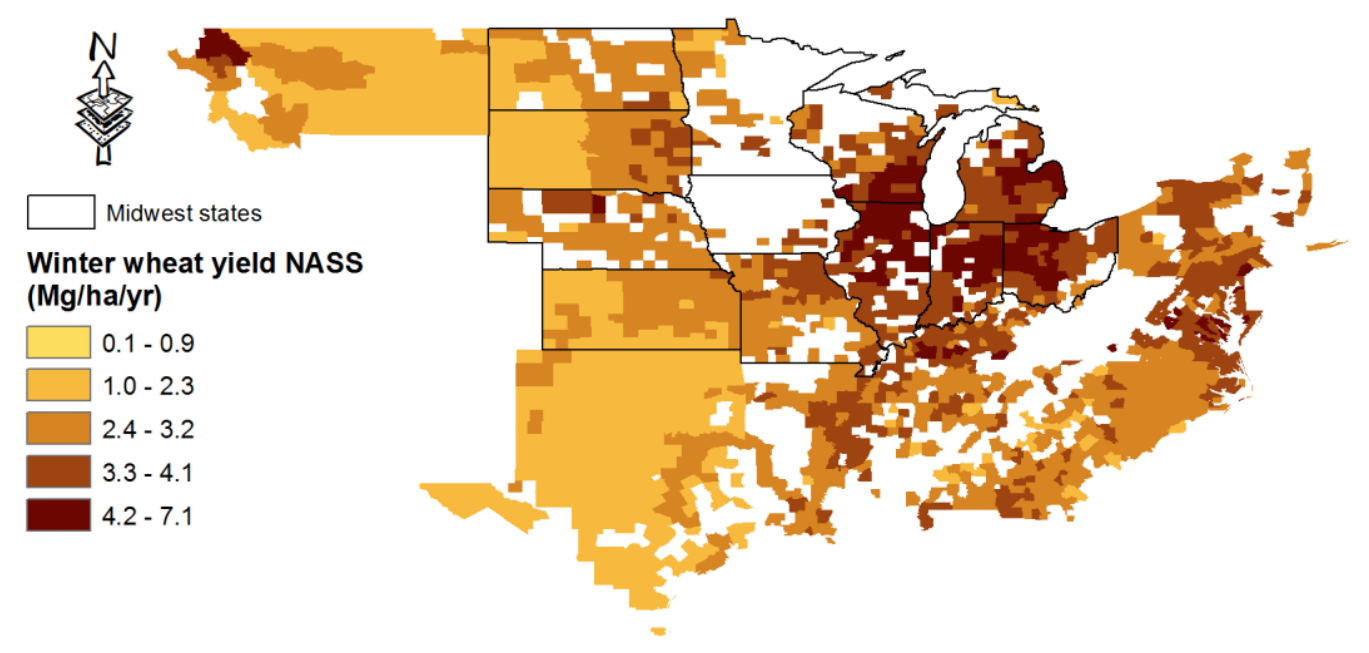

Figure 18. EPIC-simulated (dry) winter wheat yields simulated at HSMU scale and aggregated to county scale.

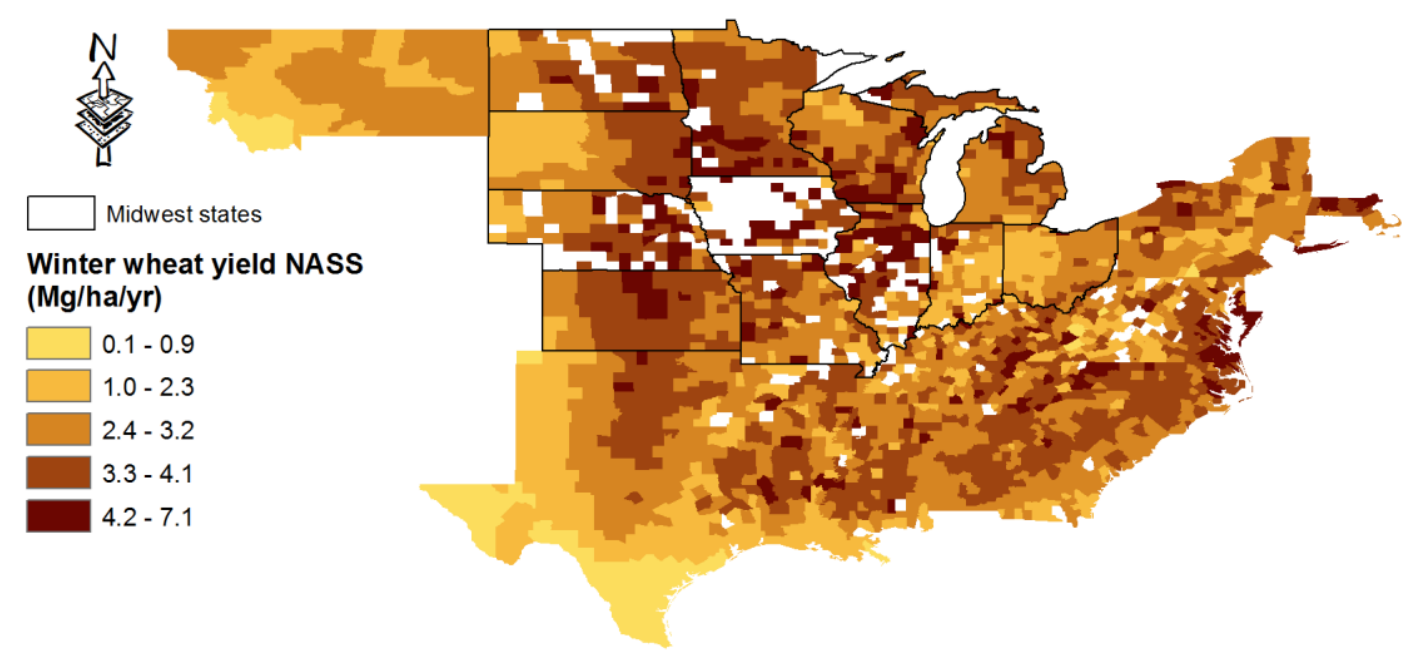

Figure 19. County (dry) winter wheat yields reported by NASS. 
Table 3. Percentage of Bias of EPIC simulated winter wheat yields across 29 states.

\begin{tabular}{cccccccc}
\hline State & NASS & EPIC & PBIAS & State & NASS & EPIC & PBIAS \\
\hline Alabama & 2.68 & 2.79 & $4.38 \%$ & Nebraska & 2.77 & 3.55 & $28.27 \%$ \\
Arkansas & 3.10 & 3.09 & $-0.41 \%$ & New York & 3.30 & 3.22 & $-2.46 \%$ \\
Georgia & 2.85 & 3.03 & $6.15 \%$ & North Carolina & 2.91 & 3.55 & $21.91 \%$ \\
Illinois & 3.99 & 3.67 & $-8.00 \%$ & North Dakota & 2.52 & 3.19 & $26.55 \%$ \\
Indiana & 4.07 & 2.46 & $-39.50 \%$ & Ohio & 3.89 & 2.47 & $-36.55 \%$ \\
Iowa & 3.33 & 3.71 & $11.37 \%$ & Oklahoma & 1.98 & 3.16 & $59.75 \%$ \\
Kansas & 2.38 & 3.34 & $40.17 \%$ & Pennsylvania & 3.19 & 2.66 & $-16.65 \%$ \\
Kentucky & 3.53 & 2.95 & $-16.54 \%$ & South Carolina & 2.64 & 3.08 & $16.67 \%$ \\
Louisiana & 3.02 & 2.81 & $-7.23 \%$ & South Dakota & 2.72 & 3.32 & $22.10 \%$ \\
Maryland & 3.77 & 3.47 & $-7.87 \%$ & Tennessee & 3.03 & 2.84 & $-6.24 \%$ \\
Michigan & 3.79 & 3.29 & $-13.28 \%$ & Texas & 1.78 & 2.06 & $16.05 \%$ \\
Minnesota & 2.87 & 3.37 & $17.37 \%$ & Virginia & 3.73 & 3.31 & $-11.18 \%$ \\
Mississippi & 3.23 & 3.17 & $-1.80 \%$ & West Virginia & 3.35 & 3.46 & $3.23 \%$ \\
Missouri & 3.04 & 3.22 & $5.85 \%$ & Wisconsin & 3.76 & 3.52 & $-6.41 \%$ \\
Montana & 2.11 & 2.39 & $13.08 \%$ & & & & \\
\hline
\end{tabular}

\subsection{Potential Biofuel Production and Environmental Impacts of Collecting Residue from Cultivated Lands in 29 US states}

We revised the historical crop management scenario by adding 50\% residue removal from corn and winter wheat to estimate potential residue production from the 29 states. For the spin-up years of 1979 to 1999 , we did not modify the management practices. Starting in 2000, we added a baling operation to collect $50 \%$ of the residue after corn or winter wheat harvesting. This residue collection would reduce organic matter returned back to the soil, changing biogeochemical cycles, plant growth, and environmental outcomes from these cultivated lands.

We used EPIC-simulated residue yields $\left(\mathrm{Mg} \mathrm{ha}^{-1} \mathrm{yr}^{-1}\right)$ and NASS reported multi-year (20002008) average planted areas of corn and winter wheat to estimate the potential production of residue biofuel feedstocks in the 29 states. We used data from NASS rather than from CDL because crop area from CDL was less accurate than the surveyed NASS data. As expected from the reported corn- and wheat-planted areas Figure 4 and Figure 6, respectively, high-corn residue production (Figure 20) would occur mainly in the US Midwest, especially in Iowa and Illinois, while high winter wheat residue production (Figure 21) would occur in Kansas, western Oklahoma, and Montana. By using Yield $\times 0.06 \mathrm{~km} \times 0.06 \mathrm{~km} \times 380.0 \mathrm{~L} \mathrm{Mg}^{-1} \times 100=$ Yield $\times$ 136.8 Equation 1 to convert from mass of dry matter to the resulting volume of ethanol, jointly corn and winter wheat residue can produce a total of $\sim 13$ billion gallons of cellulosic ethanol, of which the US Midwest would contribute more than $80 \%$ (or about 11 billion gallons). Among the 12 US Midwest states, Illinois, Iowa, and Kansas have the highest potential to provide ethanol from corn and winter wheat residues (Table 4). 


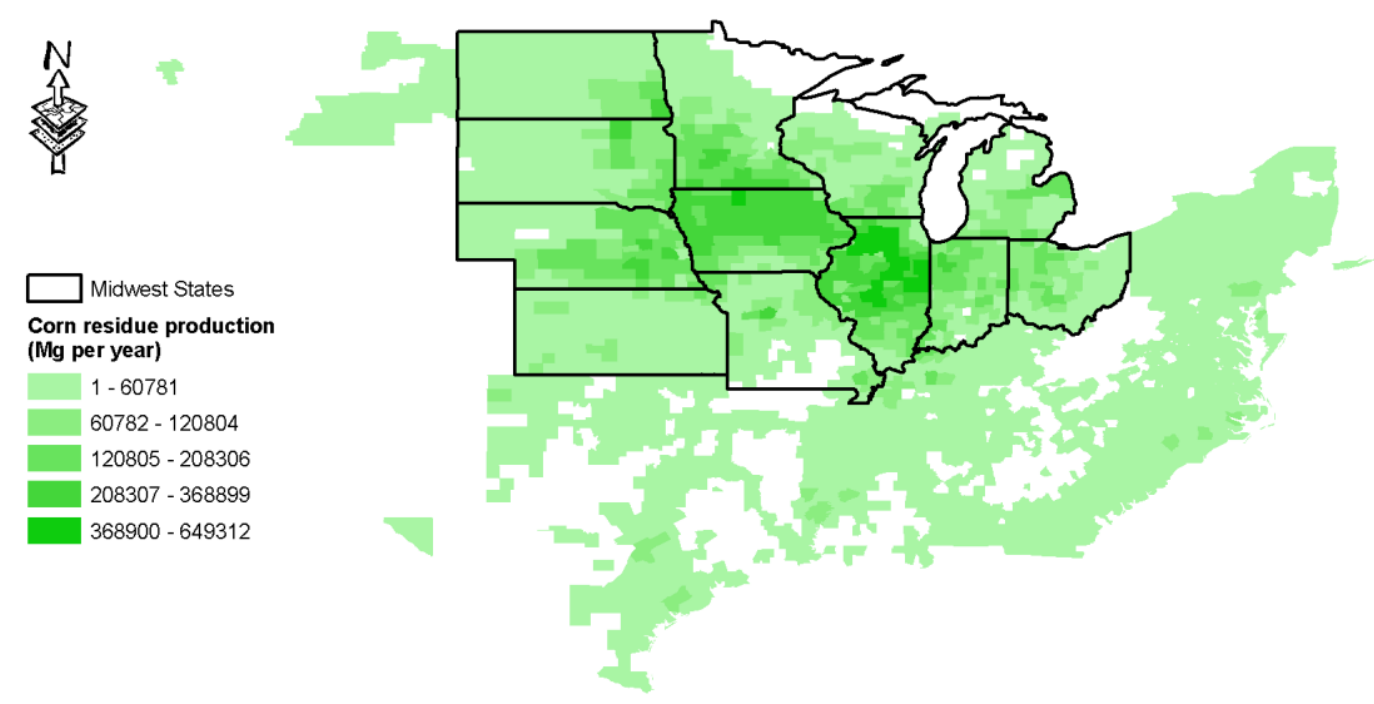

Figure 20. EPIC-simulated biomass production from corn residues assuming collection of $50 \%$ available residues.

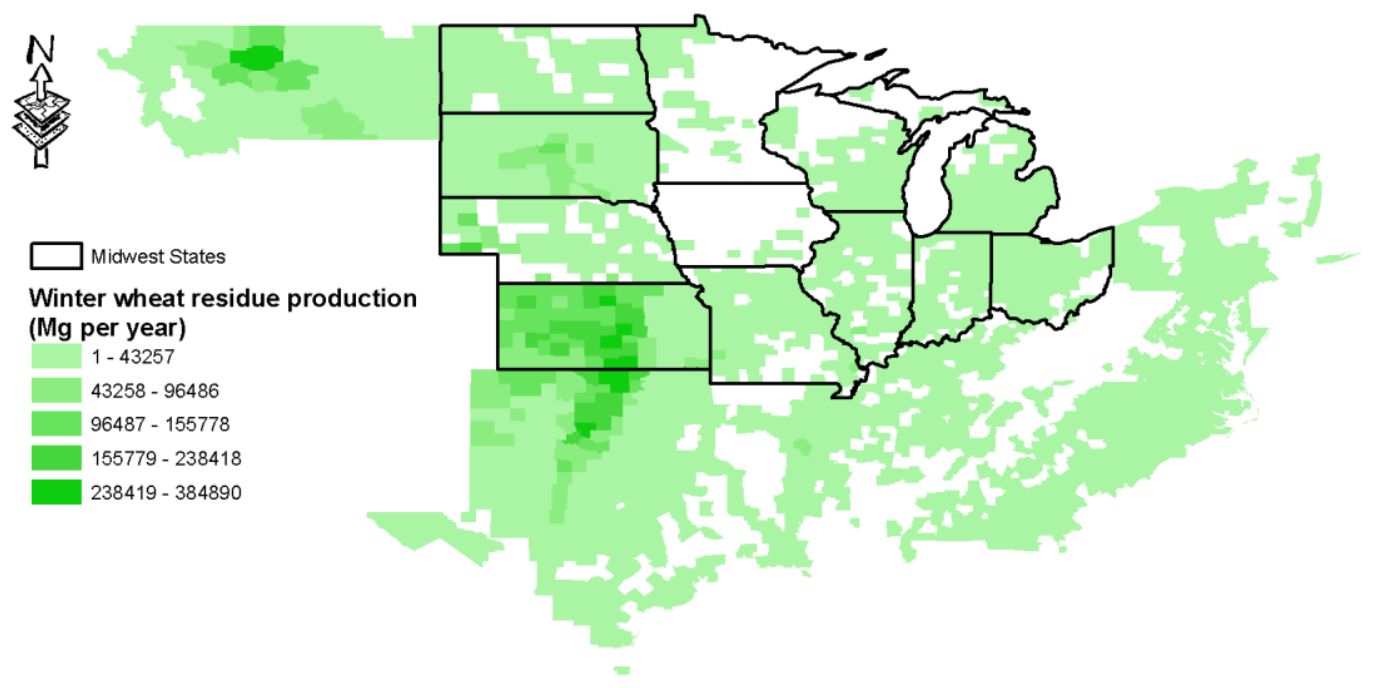

Figure 21. EPIC-simulated biomass production from winter wheat residues assuming collection of 50\% available residues.

After adding residue operations, EPIC-simulated area-averaged non-residue (grain) yields of corn, winter wheat, and soybean in the 29 states slightly increased, respectively, from 7.47 to 7.71 $\mathrm{Mg} \mathrm{ha}^{-1} \mathrm{yr}^{-1}$, from 3.02 to $3.21 \mathrm{Mg} \mathrm{ha}^{-1} \mathrm{yr}^{-1}$, and from 2.43 to $2.46 \mathrm{Mg} \mathrm{ha}^{-1} \mathrm{yr}^{-1}$ over years the 2000-2009. This increase of crop yields might be short term and attributable to a decrease in $\mathrm{N}$ immobilization because of reduced residue input to soils and an associated increase in $\mathrm{N}$ availability for plant uptake. However, in the long term (e.g. dozens of years), the continuous removal of organic matter might substantially reduce nutrient input into the soils and reduce nutrient availability for plant growth. However, due to limited availability of computational resources, we did not conduct long-term simulations, so this concern deserves further consideration for future research. 
Table 4. Potential ethanol production from corn and winter wheat residues in the US Midwest states.

\begin{tabular}{lc}
\hline State & Ethanol production \\
\hline & $----10^{6}$ gallons ---- \\
Illinois & 2,179 \\
Indiana & 878 \\
Iowa & 1,989 \\
Kansas & 1,417 \\
Michigan & 356 \\
Minnesota & 781 \\
Missouri & 512 \\
Nebraska & 994 \\
North Dakota & 170 \\
Ohio & 552 \\
South Dakota & 515 \\
Wisconsin & 360 \\
\hline
\end{tabular}

Collecting residue from farms would reduce soil cover and increase soil loss through erosion. Due to the lack of accurate information on soil conservation practices, in the EPIC simulations we did not explicitly consider the $\mathrm{P}$ factor (or conservation practice) in calculating soil erosion. The EPIC-simulated absolute values of soil erosion might deviate substantially from true soil losses from fields. Therefore, instead of analyzing the absolute change of in EPIC-simulated soil erosion, we have focused on the relative change of soil erosion denoted as the ratio between EPIC-simulated soil erosion under residue removal and historical scenarios. In general, residue removal would lead to increased soil erosion in the study region (Figure 22). In most states, the increase of soil erosion would be less than 1.3 times the baseline level. However, in Illinois, Indiana, Wisconsin, Nebraska, and Kansas, soil erosion in many counties might increase by over 1.5 times the baseline level. Overall, collecting biofuel feedstocks through residue removal may lead to significant increases in soil erosion, especially in the US Midwest.

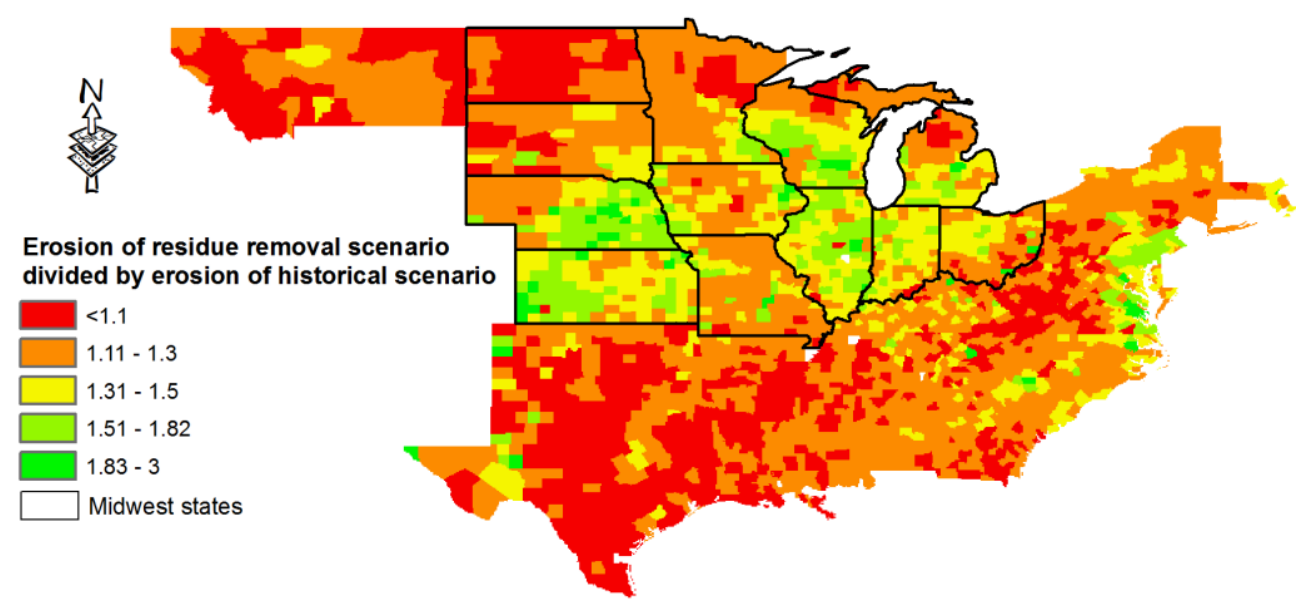

Figure 22. Ratio of water erosion between residue removal and no-residue removal scenarios. 
By collecting $50 \%$ percent of residue from corn and winter wheat fields, organic carbon returned back to soil would decrease causing less soil carbon sequestration. Figure 23 shows the difference in SOC change rates between historical and residue removal scenarios. Without residue removal, SOC change rate under historical scenario is higher than that under residue removal scenario, ranging from 21 to $1523 \mathrm{Mg} \mathrm{C}^{-1} \mathrm{yr}^{-1}$. Overall, SOC loss due to residue collection would be more prominent in Iowa, Illinois, Indiana, Ohio, and Virginia, as compared with other regions. Given the significant amount of SOC loss caused by residue removal, it is critical to careful assess of life cycle carbon balance of biofuel production using crop residue to ensure that carbon offset benefit provided by biofuel production can compensate the loss of SOC.

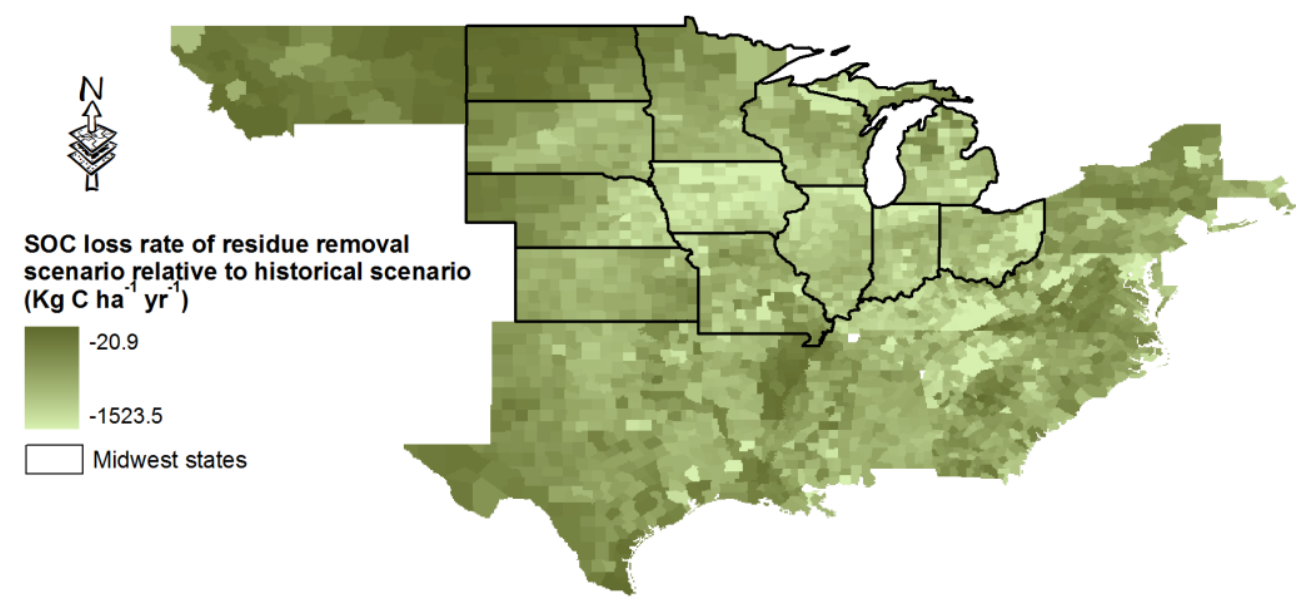

Figure 23. Difference in soil organic C (SOC) change between residue and no-residue removal scenarios.

In addition to soil erosion and SOC, nitrate leaching is another important environmental factor that may be significantly influenced by collecting crop residue for biofuel feedstocks. Implications of residue removal on the nitrogen cycle are two folds: (1) less organic nitrogen returned back to soil would decrease nitrogen input into soil and nitrate leaching; (2) On the other hand, less crop residue input to soil would immobilize less mineral nitrogen and lead to less nitrate leaching. Effects of collecting residue on nitrogen leaching are varying across the simulation region depending on other factors such as crop management, water cycle and soil properties that influence the above two processes. In most regions, residue removal would decrease or slightly increase $\left(<1 \mathrm{~kg} \mathrm{~N} \mathrm{ha}^{-1} \mathrm{yr}^{-1}\right)$ nitrogen leaching (Figure 24). However, in many counties in Nebraska, Minnesota, Iowa, Wisconsin, Illinois, and Indiana, nitrogen leaching could increase by over $5 \mathrm{~kg} \mathrm{~N} \mathrm{ha}^{-1} \mathrm{yr}^{-1}$. As these states contribute major proportion of crop residue production, it is important to consider potential negative impacts on water quality when using crop residue as biofuel stocks in order to build an environmentally sustainable bioenergy economy. 


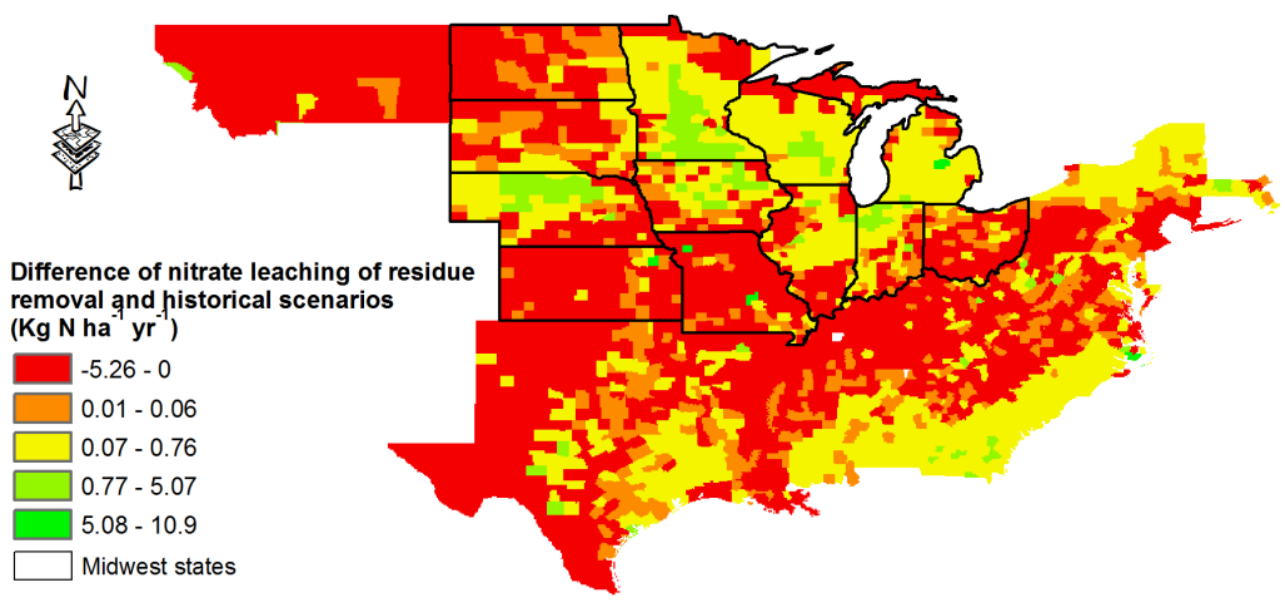

Figure 24. Difference in nitrate leaching between residue and no-residue removal scenarios.

\subsection{Potential Biomass Production from Switchgrass on Low Productive Agricultural Lands}

As for switchgrass, there is no spatially and temporally long-term observed or survey data available at large scale to quantify errors associated with EPIC simulations. Wullschleger et al. (2010) compiled a database of 1190 observations of yield from 39 field trials conducted across the US. We used this database to evaluate EPIC simulations of switchgrass yield, because it has been used in the Billion Ton Update report (Perlack et al., 2011) to estimate switchgrass production. As detailed climate, terrain, soil, crop management data were not provided for each trial, we cannot robustly evaluate EPIC performance at each field. Therefore, our purpose is to assess whether EPIC simulations fall within the range of field observations. To estimate maximum and minimum yield of switchgrass at one field, we only selected 18 field trials with over three samples. The locations of the 18 field trials (Wullschleger et al., 2010) were used to identify corresponding EPIC simulated county level switchgrass yield to compare with the field observations. Overall, EPIC simulated switchgrass yield fall within or is close to either maximum or minimum observed yield for most field trials across the 29 states of US. For two fields, one in Morgantown, West Virginia and one in Knoxville, Tennessee (Table 5), EPIC-simulated yield was considerable lower than observed minimum values. This underestimation can be explained by the lower fertilization $\left(60 \mathrm{~kg} \mathrm{ha}^{-1} \mathrm{yr}^{-1}\right)$ used in the EPIC simulation compared to the higher fertilization $\left(100 \mathrm{~kg} \mathrm{ha}^{-1} \mathrm{yr}^{-1}\right)$ used in the field experiments. The comparison results indicate that EPIC simulation of lowland switchgrass yield is comparable to that reported by Billion Ton Update report. 


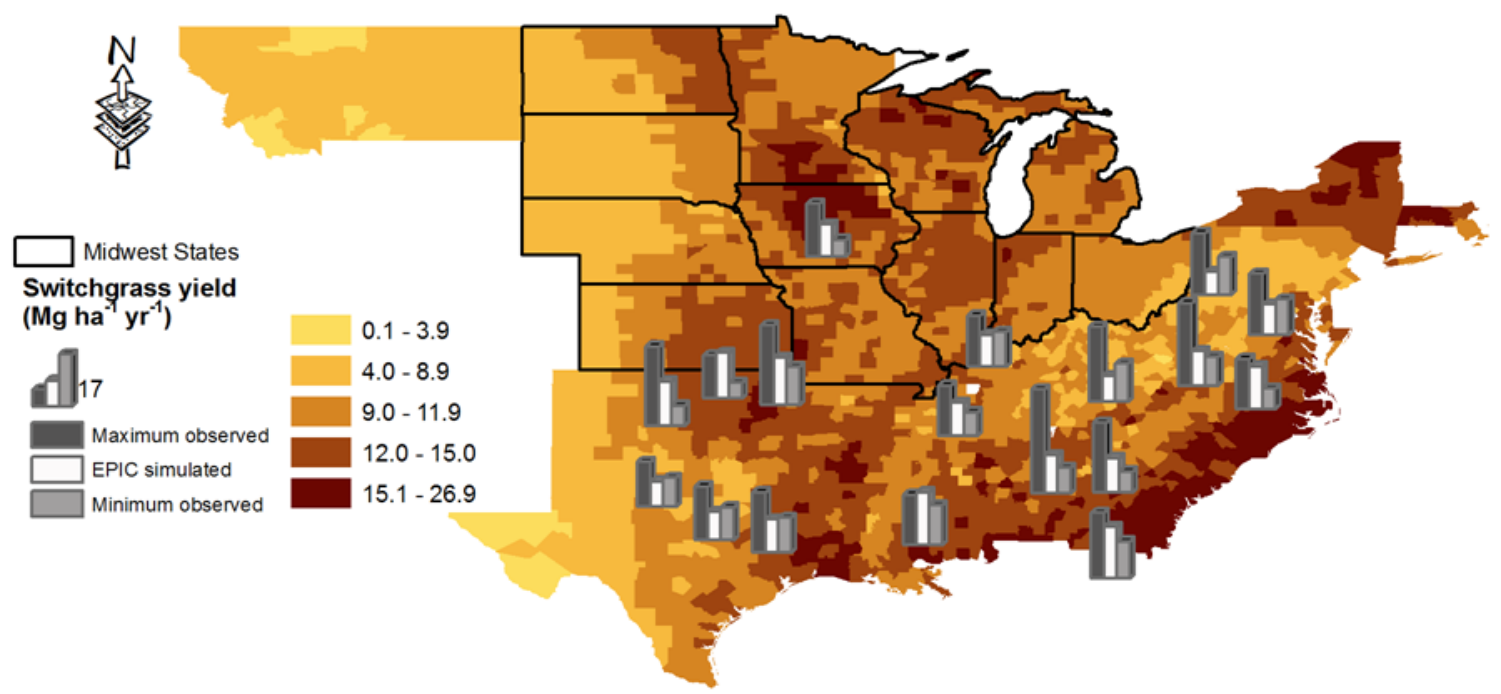

Figure 25. EPIC simulated switchgrass yields across 30 states in the conterminous USA. Sets of three bars represent a comparison between simulated and observed yields at 18 locations.

Table 5. Location, maximum and minimum of lowland switchgrass yields at 18 field trials.

\begin{tabular}{|c|c|c|c|c|c|c|c|}
\hline ID & LOCATION & STATE & MAX & MIN & $\begin{array}{c}\text { EPIC } \\
\text { simulated }\end{array}$ & Longitude & Latitude \\
\hline $1 *$ & Tifton & GA & 21.8 & 12.3 & 17.2 & -83.49 & 31.47 \\
\hline $2 *$ & Athens & GA & 23.2 & 6.9 & 11.4 & -83.41 & 33.87 \\
\hline $3^{\$}$ & $\begin{array}{l}\text { College } \\
\text { Station }\end{array}$ & TX & 20.0 & 11.6 & 11.0 & -96.35 & 30.60 \\
\hline $4^{\$}$ & Clinton & LA & 16.8 & 13.3 & 17.6 & -90.05 & 30.85 \\
\hline $5^{\$}$ & Stephenville & $\mathrm{TX}$ & 14.8 & 9.5 & 8.3 & -98.20 & 32.22 \\
\hline $6^{\&}$ & Jackson & $\mathrm{TN}$ & 16.7 & 7.8 & 11.1 & -88.83 & 35.62 \\
\hline $7^{\&}$ & Raleigh & $\mathrm{NC}$ & 16.7 & 6.9 & 14.2 & -78.67 & 35.72 \\
\hline $8^{\&}$ & Knoxville & $\mathrm{TN}$ & 24.9 & 12.5 & 8.4 & -83.95 & 35.88 \\
\hline $9^{\&}$ & Princeton & $\mathrm{KY}$ & 17.0 & 11.6 & 10.6 & -87.82 & 37.10 \\
\hline $10^{\&}$ & Blacksburg & VA & 27.4 & 9.5 & 11.4 & -80.42 & 37.18 \\
\hline $11^{\&}$ & Orange & VA & 20.4 & 11.8 & 10.1 & -78.12 & 38.22 \\
\hline $12^{\&}$ & Morgantown & WV & 20.5 & 12.7 & 7.6 & -79.95 & 39.62 \\
\hline $13^{\%}$ & Chickasha & $\mathrm{OK}$ & 26.4 & 6.7 & 14.7 & -97.91 & 35.03 \\
\hline $14^{\%}$ & Haskell & $\mathrm{OK}$ & 26.6 & 12.8 & 15.8 & -95.64 & 35.75 \\
\hline $15^{\wedge}$ & Temple & $\mathrm{TX}$ & 17.7 & 10.8 & 9.2 & -97.34 & 31.05 \\
\hline $16^{+}$ & $\begin{array}{l}\text { McNay } \\
\text { Farm }\end{array}$ & IA & 17.5 & 5.5 & 10.6 & -93.43 & 40.97 \\
\hline $17^{@}$ & Shorter & $\mathrm{AL}$ & 34.6 & 8.6 & 12.8 & -85.56 & 32.66 \\
\hline $18^{\#}$ & Perkins & $\mathrm{OK}$ & 14.3 & 5.2 & 15.2 & -97.05 & 35.99 \\
\hline
\end{tabular}

Note: *Bouton (2002); ${ }^{\text {SC}}$ Cassida et al. (2005); ${ }^{\circ}$ Fike et al. (2006); ${ }^{\%}$ Fuente and Taliaferro (2002); ${ }^{\wedge}$ Kiniry et al. $(1996)$; ${ }^{+}$Lemus et al. (2002); ${ }^{\circledR}$ Sladden et al. (1991); ${ }^{\#}$ Thomason et al. (2004). 
Although Iowa, Illinois, and other Midwest states have large area of agricultural lands, not many cultivated lands with low productivity are available in these states. Montana, North Dakota, South Dakota, Nebraska, and Kansas have relatively large area of cultivated lands with land capability of IV - VII (Figure 26). On these soils relatively poor quality soils, switchgrass yield is much lower as compared with that on all cultivated lands that also include productive lands (Figure 27). To some extent, the use of less productive cultivated lands to grow switchgrass for biofuel would loosen the tension of food and energy competition.

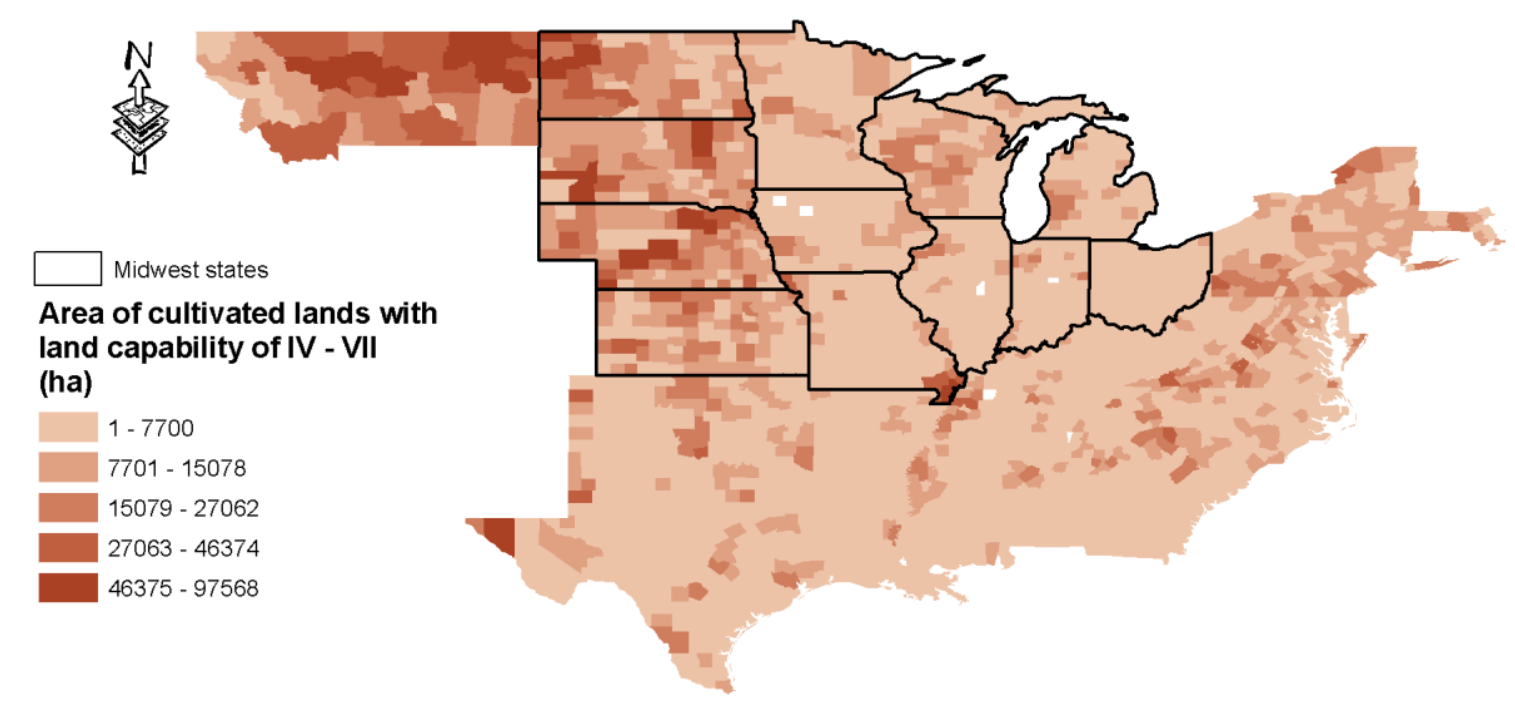

Figure 26. Area of cultivated land with land capability classes IV - VII.

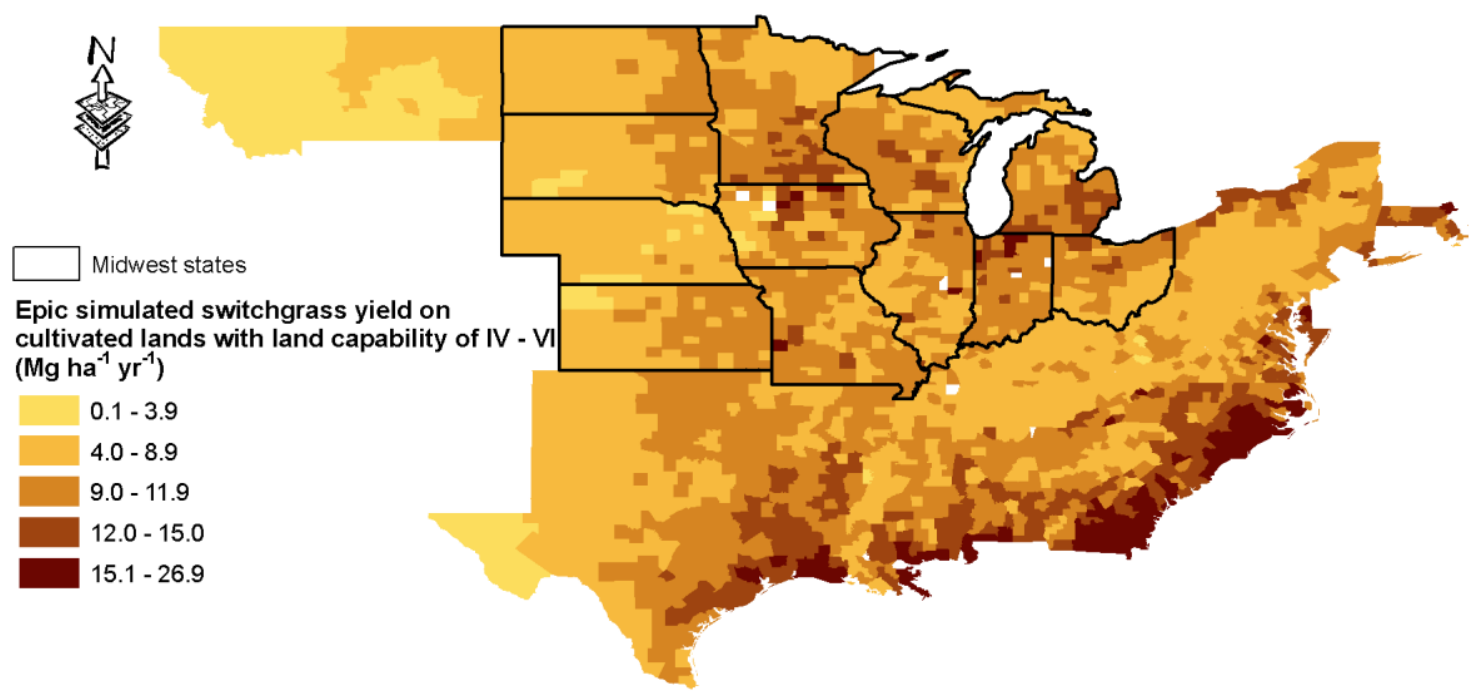

Figure 27. EPIC simulated yields of switchgrass on cultivated land with land capability classes IV - VI. 
Consistent with the pattern of cultivated lands with low productivity, Montana, North Dakota, South Dakota, Nebraska, and Kansas can potentially contribute significant amount of cellulosic ethanol, although the switchgrass yield is these regions is relatively low (Figure 28). Furthermore, some counties in Wisconsin, Michigan, Missouri, Pennsylvania, and Texas can potentially supply switchgrass biomass to produce large amounts of cellulosic ethanol (> 15,000,000 gallons).

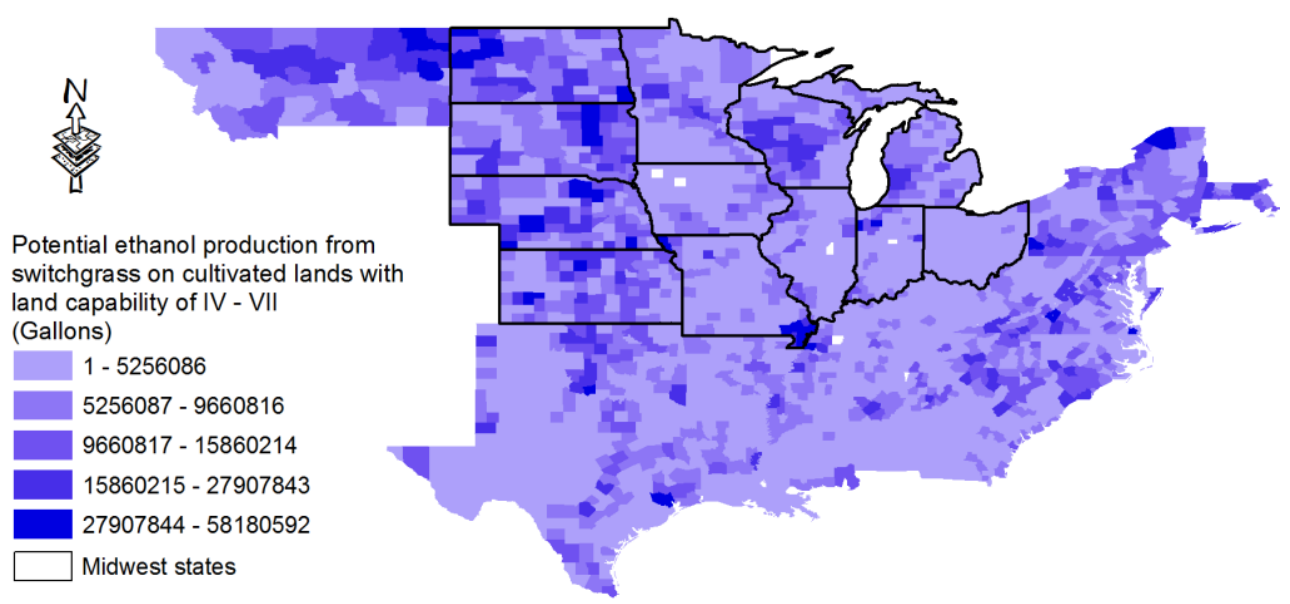

Figure 28. Potential cellulosic ethanol production from switchgrass on cultivated lands with land capability classes IV - VII.

\subsection{Potential Cellulosic Biomass Production from Marginal Lands}

The following analysis is from a submitted manuscript on sustainable bioenergy production (Gelfand et al., submitted). For each grid of marginal land, we simulated ANPP by the calibrated EPIC model under three levels of $\mathrm{N}$ fertilization: 0,68 , and $123 \mathrm{~kg} \mathrm{~N} \mathrm{ha}^{-1} \mathrm{yr}^{-1}$. Modeled field size for the estimation of potential productivity varied substantially, with a minimum size of $3,600 \mathrm{~m}^{2}$ and a maximum of $>650 \times 10^{6} \mathrm{~m}^{2}$. Overall, we simulated 78,184 fields having unique combinations of soil type, land-use, and LCC. The connectivity between each field and nearby fields was not assessed. Average biomass yields $\left(\mathrm{Mg} \mathrm{ha}^{-1} \mathrm{yr}^{-1}\right)$ for 78,184 parcels of marginal land as modeled by EPIC for three levels of $\mathrm{N}$ fertilizer application and two harvest efficiencies are presented in Table 6 . Values in parentheses are standard deviations. Ethanol yields are based on a conversion factor of $380.0 \mathrm{~L} \mathrm{Mg}^{-1}$ of cellulosic biomass.

\subsubsection{Comparison with Estimates from Billion Ton Study Update}

We also compared our results of biomass production rates with recent Billion-Ton Study Update (Perlack et al. (2011) (Table 7). Our estimation differs significantly and exhibited no relation to the Billion-Ton Study $\left(\mathrm{R}^{2}=0.004\right)$. The Spearman rank-order correlation coefficient $\left(r_{s}\right)$ is -0.0061 with a p-value of 0.98 . An $r_{s}$ value below 0 implies negative agreement between the two rankings.

Table 6. Average biomass yields $\left(\mathrm{Mg} \mathrm{ha}^{-1} \mathrm{yr}^{-1}\right)$ for 78,184 parcels of marginal land as modeled by EPIC for two harvest efficiencies and three $\mathrm{N}$ levels (Gelfand et al., submitted).

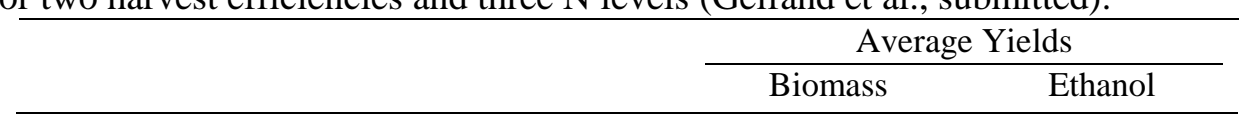




\begin{tabular}{lccc}
\hline & & $\mathrm{Mg} \mathrm{ha}^{-1} \mathrm{yr}^{-1}$ & $\mathrm{~L} \times 10^{3} \mathrm{ha}^{-1} \mathrm{yr}^{-1}$ \\
Harvest efficiency (\%) & 55 & $4.3(1.7)$ & $1.6(0.6)$ \\
& 90 & $6.0(2.6)$ & $2.3(1.0)$ \\
$\mathrm{N}$ Fertilization $\left(\mathrm{kg} \mathrm{ha}^{-1} \mathrm{yr}^{-1}\right) \dagger$ & 0 & $6.0(2.6)$ & $2.3(1.0)$ \\
& 68 & $8.2(2.7)$ & $3.1(1.0)$ \\
& 123 & $8.9(2.8)$ & $3.3(1.0)$ \\
\hline Simulations under different N fertilization regimes assuming $90 \%$ harvest efficiency.
\end{tabular}

Table 7. EPIC simulated and Billion-Ton Study Update (BTS-U) estimated biomass yields on marginal lands across the 10-state US Midwest Region (Gelfand et al., submitted).

\begin{tabular}{lcc}
\hline & \multicolumn{2}{c}{ Average biomass yield } \\
\cline { 2 - 3 } & EPIC* & BTS-U \\
\hline & -------- Mg ha $^{-1}$ & --------- \\
Illinois & 8.16 & 12.52 \\
Indiana & 8.35 & 13.07 \\
Iowa & 7.81 & 11.73 \\
Michigan & 9.98 & 7.44 \\
Minnesota & 10.63 & 6.04 \\
Nebraska & 6.01 & 8.87 \\
North Dakota & 5.55 & 4.59 \\
Ohio & 7.16 & 14.03 \\
South Dakota & 4.75 & 7.59 \\
Wisconsin & 8.96 & 10.29 \\
\hline
\end{tabular}

* EPIC simulated for unfertilized marginal land.

\subsubsection{Locating Biorefineries in 10 States of the US Midwest Region}

We implemented a moving window algorithm to assess availability of cellulosic biofuel from marginal lands in the 10-State US Midwest region. The placement of biorefineries for cellulosic biomass production from marginal lands in 10 states of the US Midwest is shown in Figure 29. Each circle represents an $80 \mathrm{~km}$ radius area with sufficient biomass resources to produce at least $89.3 \mathrm{ML}$ ethanol $\mathrm{yr}^{-1}$ based on quantitative simulation of yields from non-forested marginal lands at a $60 \times 60 \mathrm{~m}$ resolution. Corn acreages (in ha) by county have been derived from the CDL of 2008. The inset map shows a close up of a potential biorefinery location where the yield is not clearly visible on the main map. Figure 30 shows the placement of biorefineries for cellulosic biomass production from marginal lands in ten states of the US Midwest with identification numbers corresponding to Table 8. Overall, our results show that $\sim 21 \mathrm{GL}$ ( 5.6 billion gallons $\mathrm{yr}^{-1}$ ) of cellulosic ethanol could be produced (Table 8), meeting $~ 30 \%$ of the 2022 target for cellulosic biofuel mandated by the 2007 US Energy Independence and Security Act. 


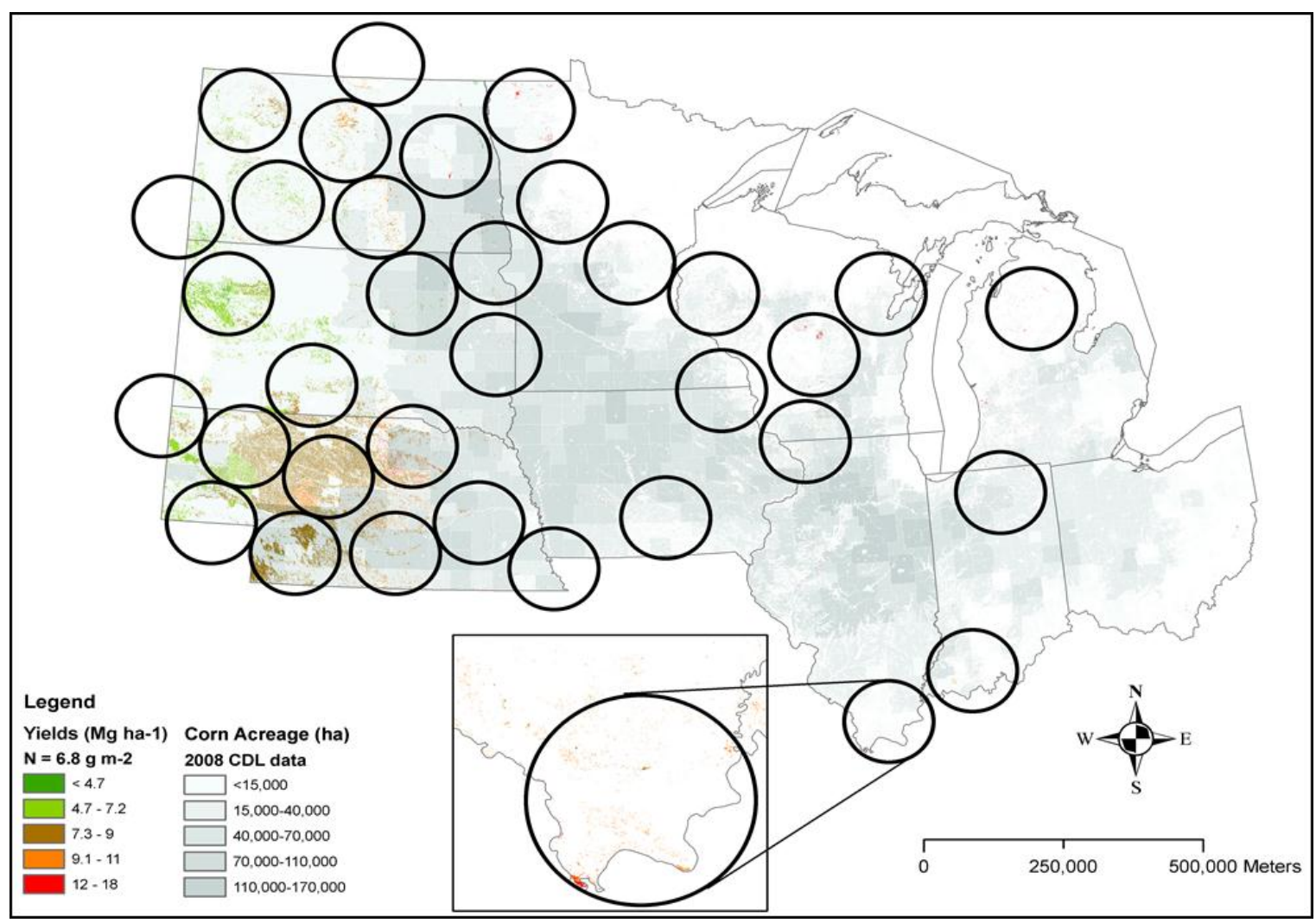

Figure 29. Biomass yields and potential cellulosic ethanol biorefinery locations in the 10-state US Midwest. Region (Gelfand et al., submitted).

\subsubsection{Cellulosic Biomass Production in the Sandhills of Nebraska}

The Sandhills region of Nebraska is dominated by grass-stabilized sand dunes underlain by the Ogallala aquifer. It is a fragile ecosystem with the predominant land-use being livestock grazing. Here, the marginal lands that are suitable for cultivation of perennial biofuel crops (native prairie mixes, switchgrass and miscanthus) are examined for their respective environmental impacts. 
Table 8. EPIC modeled biomass and cellulosic ethanol production by state assuming $90 \%$ harvest efficiency and two N-fertilization levels $\left(0\right.$ and $\left.68 \mathrm{~kg} \mathrm{ha}^{-1}\right)$.

\begin{tabular}{|c|c|c|c|c|c|}
\hline \multirow[b]{2}{*}{$\mathrm{ID}^{\S}$} & \multirow[b]{2}{*}{ State $^{\dagger}$} & \multicolumn{2}{|c|}{ Total biomass production } & \multicolumn{2}{|c|}{$\begin{array}{l}\text { Total cellulosic ethanol } \\
\text { production }\end{array}$} \\
\hline & & $\mathrm{F}^{*}=0$ & $\mathrm{~F}=68$ & $\mathrm{~F}=0$ & $\mathrm{~F}=68$ \\
\hline & & \multicolumn{2}{|c|}{------- $\mathrm{Mg} \times 10^{6}$} & \multicolumn{2}{|c|}{------- GL yr ${ }^{-1}$------- } \\
\hline 1 & Illinois & 1.35 & 1.88 & 0.18 & 0.26 \\
\hline 2 & Illinois 1 & 0.67 & 0.8 & 0.09 & 0.11 \\
\hline 3 & Indiana & 1.18 & 1.43 & 0.16 & 0.19 \\
\hline 4 & Indiana $1 \%$ & 0.77 & 0.96 & 0.11 & 0.13 \\
\hline 5 & Iowa & 1.67 & 2.27 & 0.23 & 0.31 \\
\hline 6 & Iowa $1 \ddagger$ & 0.87 & 1.17 & 0.12 & 0.16 \\
\hline 7 & Michigan & 1.78 & 2.29 & 0.24 & 0.31 \\
\hline 8 & Minnesota & 2.38 & 2.55 & 0.32 & 0.35 \\
\hline 9 & Minnesota 1 & 0.86 & 1.10 & 0.12 & 0.15 \\
\hline 10 & Minnesota 2 & 0.90 & 1.11 & 0.12 & 0.15 \\
\hline 11 & Nebraska & 13.72 & 19.13 & 1.88 & 2.62 \\
\hline 12 & Nebraska $1 \ddagger$ & 10.44 & 14.66 & 1.43 & 2.01 \\
\hline 13 & Nebraska $2 \ddagger$ & 9.75 & 13.83 & 1.33 & 1.89 \\
\hline 14 & Nebraska 3 & 8.89 & 11.54 & 1.22 & 1.58 \\
\hline 15 & Nebraska 4 & 6.43 & 9.01 & 0.88 & 1.23 \\
\hline 16 & Nebraska $5 \ddagger$ & 4.05 & 5.33 & 0.55 & 0.73 \\
\hline 17 & Nebraska 6 & 2.55 & 3.40 & 0.35 & 0.46 \\
\hline 18 & Nebraska $7 \ddagger$ & 1.68 & 2.30 & 0.23 & 0.31 \\
\hline 19 & Nebraska 8 & 0.61 & 0.80 & 0.08 & 0.11 \\
\hline 20 & North Dakota & 5.48 & 7.50 & 0.75 & 1.03 \\
\hline 21 & North Dakota 1 & 4.01 & 5.19 & 0.55 & 0.71 \\
\hline 22 & North Dakota 2 & 3.75 & 5.12 & 0.51 & 0.70 \\
\hline 23 & North Dakota 3 & 3.59 & 4.62 & 0.49 & 0.63 \\
\hline 24 & North Dakota $4 \ddagger$ & 1.52 & 1.89 & 0.21 & 0.26 \\
\hline 25 & North Dakota 5 & 1.28 & 1.80 & 0.17 & 0.25 \\
\hline 26 & North Dakota $6 \$$ & 0.74 & 0.95 & 0.10 & 0.13 \\
\hline 27 & South Dakota & 7.22 & 10.97 & 0.99 & 1.50 \\
\hline 28 & South Dakota $1 \ddagger$ & 4.25 & 6.07 & 0.58 & 0.83 \\
\hline 29 & South Dakota 2 & 1.97 & 2.77 & 0.27 & 0.38 \\
\hline 30 & South Dakota $3 \ddagger$ & 1.86 & 2.42 & 0.26 & 0.33 \\
\hline 31 & South Dakota $4 \ddagger$ & 0.93 & 1.22 & 0.13 & 0.17 \\
\hline 32 & Wisconsin & 1.64 & 2.03 & 0.22 & 0.28 \\
\hline 33 & Wisconsin $1 \ddagger$ & 1.20 & 1.58 & 0.16 & 0.22 \\
\hline 34 & Wisconsin $2 \ddagger$ & 0.53 & 0.65 & 0.07 & 0.09 \\
\hline
\end{tabular}

$* \frac{34}{\mathrm{~N}}$ fertilizer application in $\mathrm{kg} \mathrm{N}^{-1} \mathrm{yr}^{-1}$.

${ }^{\dagger}$ If more than one potential biorefinery could be placed in a state, we name potential placements with serial numbers.

\$Biomass collection for the biorefinery location involves collection across state boundaries.

$\S$ Biorefinery placements associated with biorefinery ID are presented in Figure 30. 
Marginal lands were defined from the point of view of biophysical productivity as well as topographical characteristics. SSURGO data was used to define marginal land as land falling into Land Capability Classes of V-VII with current land cover being field crops (e.g. corn, soybean, etc.) or herbaceous vegetation (e.g., pastureland, rangeland, CRP, etc.) and with slope gradients $<20 \%$. Special consideration was given to the Sandhills of Nebraska whose unique grassstabilized sand dune topography distinguishes them from the surrounding prairies (Eggemeyer et al., 2006). The sand dunes can be hundreds of meters tall and several kilometers long. The interdune valleys are the largest sources of hay for the cattle industry in Nebraska (Gosselin et al., 2006). To keep only the inter-dune valleys and exclude the fragile dune ridges and slopes from the analysis the Topographic Position Index (TPI) algorithm available in ArcGIS (Tagil and Jenness, 2008) was used.

The TPI is a classification scheme based on the difference in elevation values between a cell in a DEM raster and its neighbors. The extent to which a cell is higher or lower as compared to its neighbors, combined with its slope, can be used to assign it a landform classification like valley, ridge etc. Removing the dune ridges and slopes from the analysis reduced the area available for consideration as marginal lands by more than 200,000 ha. The inter-dune valleys falling under LCC V-VII and with slope gradients $<20 \%$ were then used for further analysis using EPIC model.

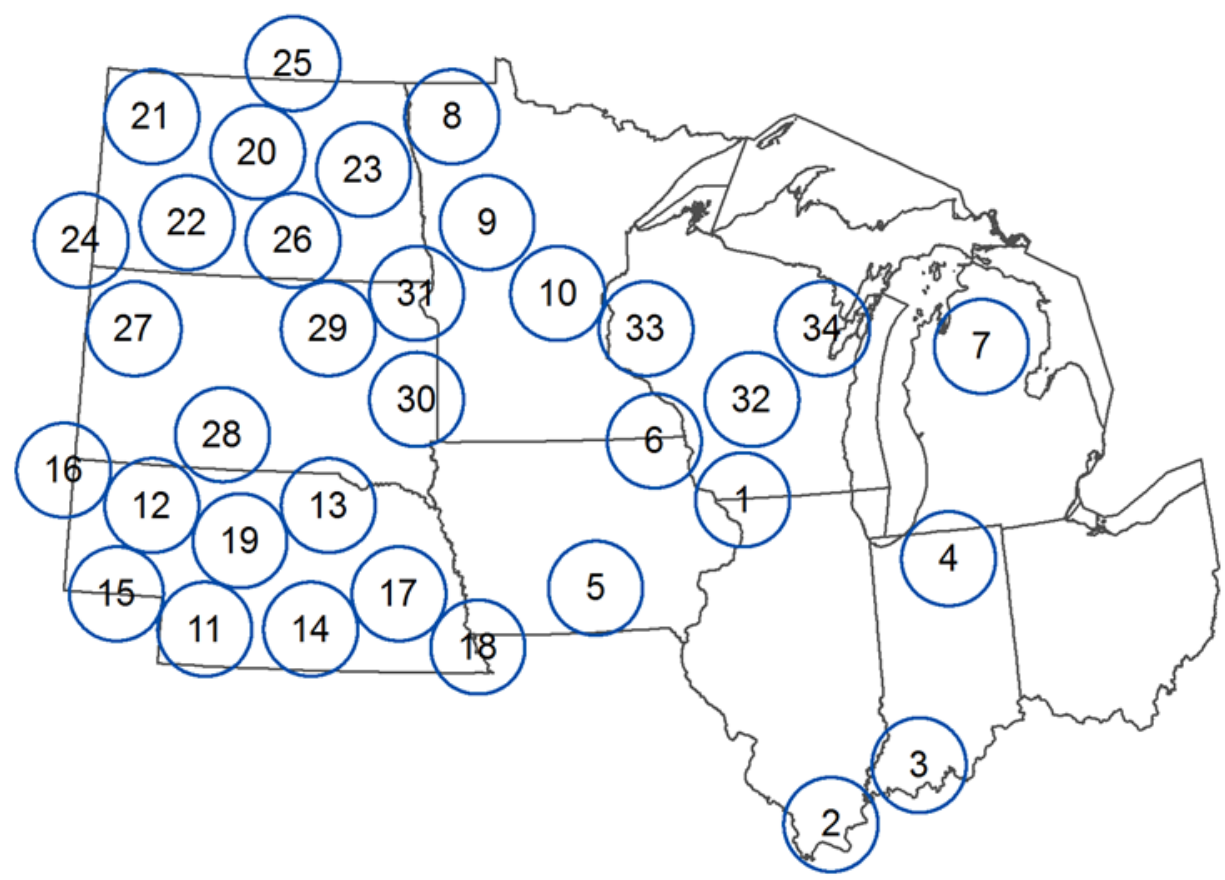

Figure 30. The placement of biorefineries for cellulosic biomass production from marginal lands in 10 states of the US Midwest with identification numbers corresponding to Table 8 (Gelfand et al., submitted).

\subsection{Potential Biomass Supply from CRP lands in lowa}

On nearly 270,000 hectares of CRP, we estimated that $3.2 \mathrm{Tg}$ of switchgrass and $2.1 \mathrm{Tg}$ of perennial mixture biomass could be harvested per year. Switchgrass yields varied from 4.5 to 
20.5 $\mathrm{Mg} \mathrm{ha}^{-1}$, with an average of $11.9 \mathrm{Mg} \mathrm{ha}^{-1}$. Correspondingly, perennial mixture yields varied from 4.8 to $16.7 \mathrm{Mg} \mathrm{ha}^{-1}$, and averaged $7.8 \mathrm{Mg} \mathrm{ha}^{-1}$. Compared with the non-harvesting perennial mixture baseline scenario, switchgrass and the perennial mixtures, with harvesting, reduced soil $\mathrm{C}$ stocks by 2.9 and $1.4 \mathrm{Mg} \mathrm{Cha}^{-1} \mathrm{yr}^{-1}$, respectively, over the 12-year simulation period (Figure 31). Due to harvesting that remove nitrogen from fields, switchgrass and perennial mixture produce less $\mathrm{N}$ export (Figure 32). Overall, perennial mixtures perform better than switchgrass for nitrogen and soil $\mathrm{C}$ conservation.

Geo-spatial analysis was used to identify potential ethanol biorefinery locations. Here we assumed biorefineries only draw biomass within a radius of $80 \mathrm{~km}$. Our results show that, from CRP lands in Iowa, planting perennial mixture can produce biomass that can be used to produce a total of 202 million gallon of cellulosic ethanol. Moving window analysis identified three biorefineries with annual production capacity $>25$ million gallons (Figure 33).

Overall, the analysis shows that CRP lands can be used to produce cellulosic biofuels feedstocks for future cellulosic ethanol biorefineries. However, harvesting cellulosic biomass from CRP lands may lead to degradation of ecosystem services provided by CRP lands with respect to nitrogen and carbon cycling.

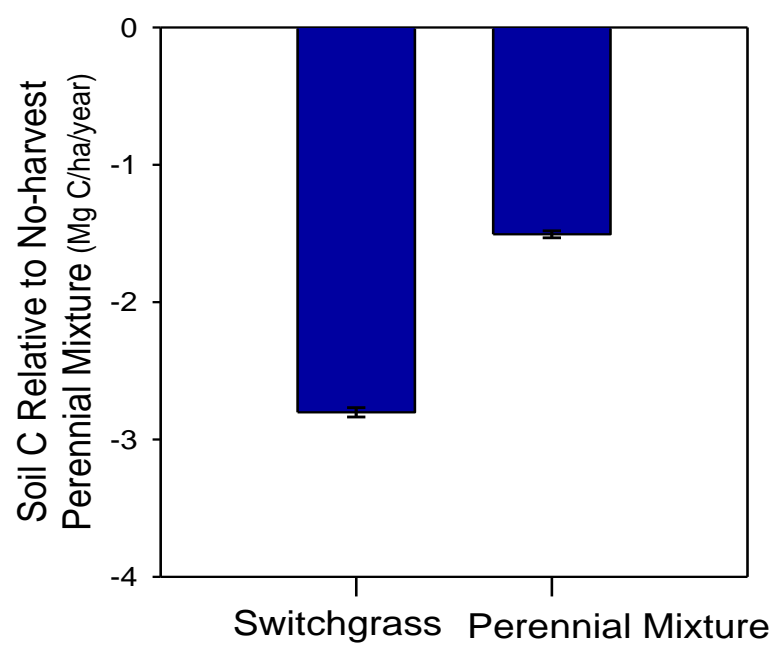

Figure 31. Soil-C change ratio in harvested vs. unharvested perennial mixtures. 


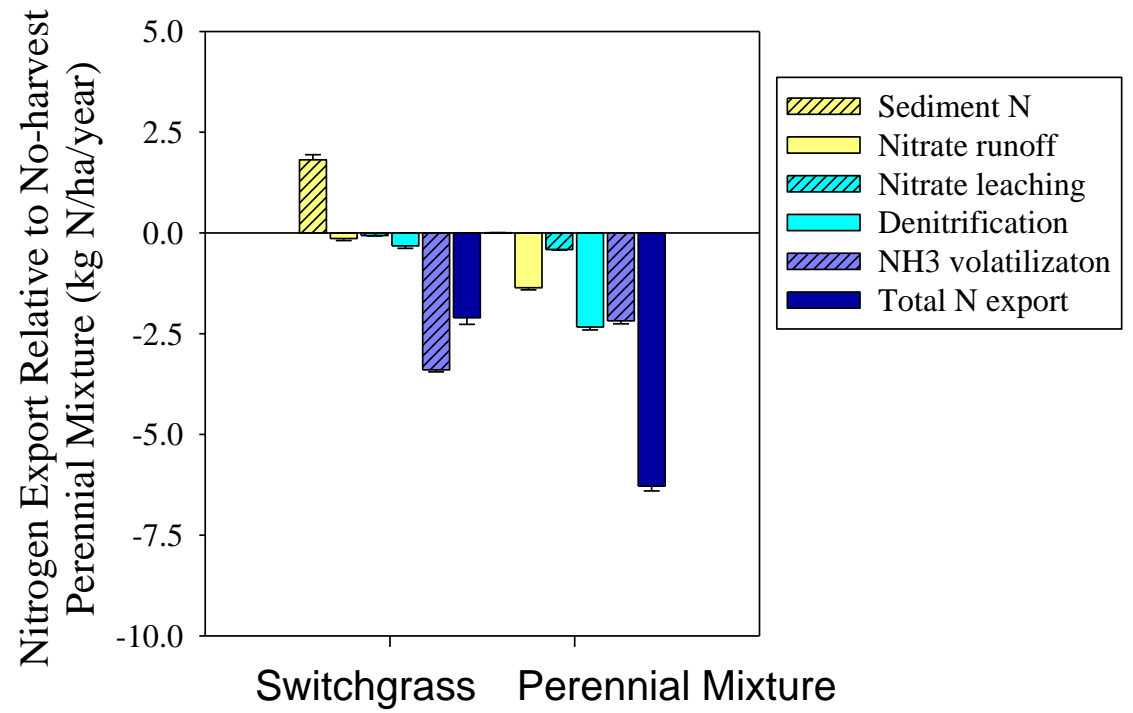

Figure 32. Nitrogen export by treatment relative to no-harvest perennial mixture.

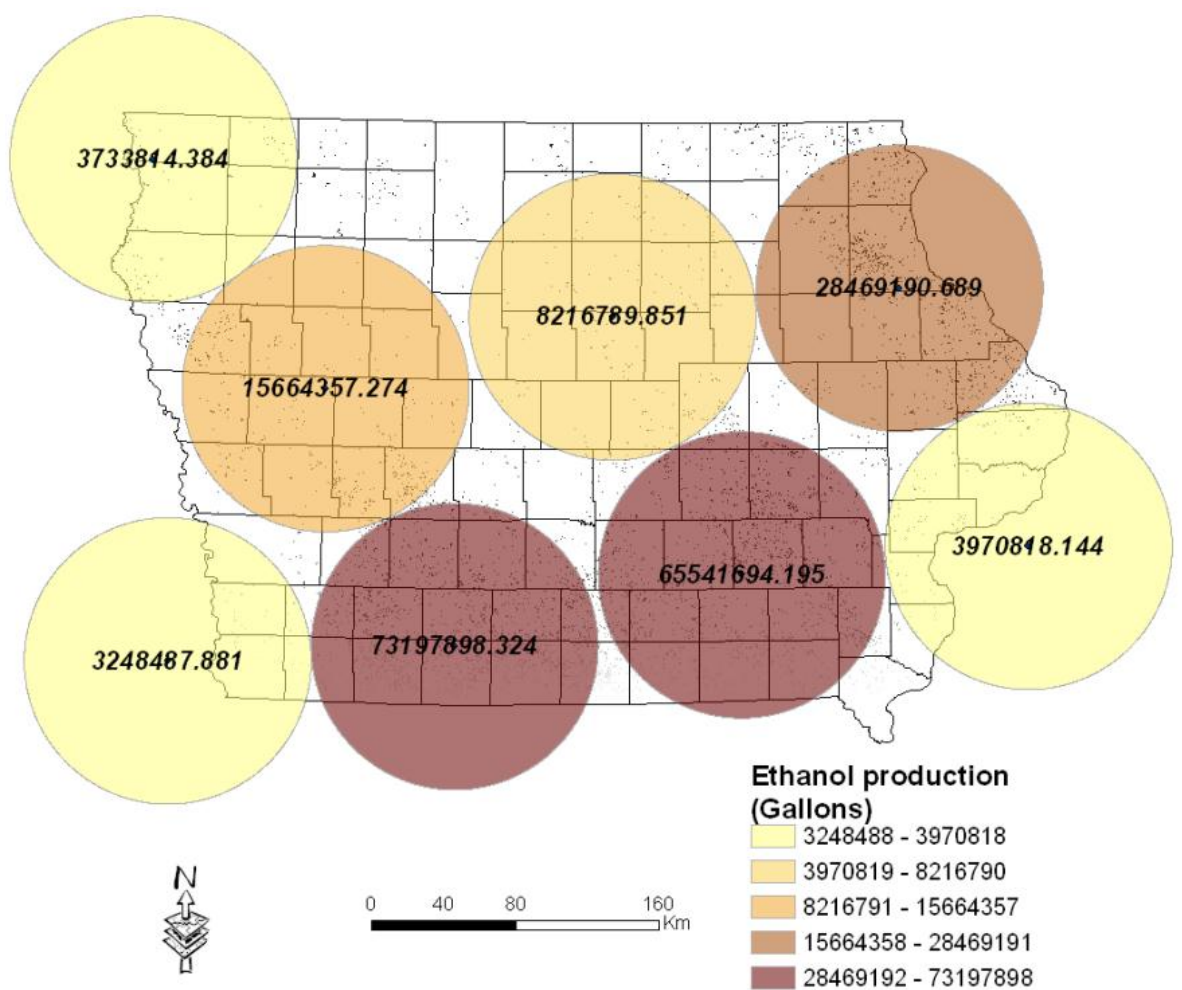

Figure 33. Location of potential ethanol biorefineries (circles with $80 \mathrm{~km}$ radius) drawing cellulosic feedstock from perennial mixtures grown on CRP lands. 


\subsection{Summary and Conclusions}

We have developed a spatially explicit geodatabase containing data for 30 of the primary agricultural states for the primary purpose of conducting simulation studies of potential biofuel scenarios. In addition, we have used this geodatabase to perform three simulation studies in these states using the EPIC biogeochemical model: a historical baseline scenario of corn, soybean, and wheat rotations; an augmented historical scenario with removal of biomass residues from corn and wheat; and a simulation of switchgrass yields. The results of this study will be submitted to the USDOE Bioenergy Knowledge Discovery Framework as a way to contribute to the development of a sustainable bioenergy industry.

In order to perform these high-resolution analyses, it was vital to have a computing infrastructure in place that would allow us to simulate approximately 2 million individual land units for each of the three scenarios and would allow us to aggregate and visualize the resulting data. The first part of this infrastructure was the server "deltac": an eight-core Linux server, acquired with ARRA support, used to conduct the initial county-level and state-level simulations and host the PostgreSQL database where data from the national-scale simulations were stored. The second part of the infrastructure was the "Evergreen" cluster, A DOE-JGCRI resource colocated at UMD, which allowed for the processing of the 2 million simulations in a relatively short period. Though it took some time to modify our processes to take advantage of the size of the Evergreen cluster, it allowed us to perform these large-scale simulations. Had we not received funding for these vital resources, this report would not have been possible in the time allotted.

Looking at the baseline scenario, we see that EPIC is able to capture well the trends in corn, soybean and winter wheat yields in the US Midwest except for a) states where irrigation is prominent and the lack of simulation results on irrigated corn and 2) accuracy of CDL for identifying wheat lands. Building off these baseline results, we then estimated that 13 billion gallons of cellulosic ethanol per year could be generated by collecting half of available corn and wheat residues. In other words, slightly more than one third of the total cumulative 2022 ethanolblending requirement in the 2007 Energy Independence and Security Act could be produced from these residues annually.

However, this level of cellulosic biofuel production largely comes with associated additional environmental costs. In particular, soil organic carbon (SOC) would be lost at a greater rate than in the baseline scenario. Soil erosion would increase as well. Given the significant increase in SOC losses in some areas, it is critical to evaluate carefully the life cycle carbon balance of residue-based biofuel production to ensure that there is still at net decrease in GHG emissions once these losses are taken into account. One potential positive environmental outcome of this biofuel production would be a decrease in nitrogen leaching relative to the baseline scenario in many areas. In the vast majority of the 30 states, this leaching would either decrease or increase by less than $1 \mathrm{~kg} \mathrm{~N}^{-1} \mathrm{yr}^{-1}$ versus the baseline. Nevertheless, in many counties in Nebraska, Minnesota, Iowa, Wisconsin, Illinois, and Indiana, nitrogen leaching could increase by over $5 \mathrm{~kg}$ $\mathrm{N} \mathrm{ha}^{-1} \mathrm{yr}^{-1}$. As well, it is unclear if these trends would continue long-term.

Perennial grasses such as switchgrass have also been considered as possible sources of cellulosic ethanol, particularly on lands that are generally unprofitable for growing other crops, so 
we have also simulated potential switchgrass yields and environmental outcomes across these 30 states in order to evaluate these claims. Unfortunately, there is not any current large-scale switchgrass productivity data, as with common field crops, so we could not perform the same sort of baseline evaluation. Instead, we compared our baseline scenario to the recent Billion-Ton Update report. The comparison results indicated that the EPIC-simulated yields of lowland switchgrass compared favorably to those reported in the Billion-Ton Update report.

When looking at land that would be considered marginal for growing typical field crops, Montana, North Dakota, South Dakota, Nebraska, and Kansas stand out with relatively large areas of cultivated lands that fall under land capability classes IV - VII (Figure 26). On these soils with relatively poor quality for crop growth, switchgrass yield would be lower than the yields on all currently cultivated lands (Figure 27). However, we determined that 34 potential biorefineries could be situated among ten of the Midwestern states, each of which could produce at least 89.3 ML ethanol $\mathrm{yr}^{-1}$ (23.6 million gallons $\mathrm{yr}^{-1}$ ) (Figure 28). Spatially explicit biophysical modeling of cellulosic feedstock production on marginal lands within $80 \mathrm{~km}$ of a potential biorefinery suggested an annual potential ethanol production of $\sim 21 \mathrm{GL} \mathrm{yr}^{-1}$ (5.6 billion gallons $\mathrm{yr}^{-1}$ ), or $\sim 30 \%$ of the 2022 target for cellulosic biofuel mandated by US legislation. Adding lands from the conservation reserve program (CRP) could also result in significant amounts of ethanol from switchgrass. For example, from Iowa alone, an additional eight biorefineries could be situated using biomass from CRP lands. However, harvesting cellulosic biomass from CRP lands might lead to degradation of ecosystem services provided by these lands, particularly with respect to nitrogen and carbon cycling, so further study of their would be needed.

In summary, we have reported on the development of a spatially explicit national geodatabase to conduct biofuel simulation studies and provided initial simulation results on the potential of annual and perennial cropping systems to serve as feedstocks for the production of cellulosic ethanol. To accomplish this, we have employed sophisticated spatial analysis methods in combination with the process-based biogeochemical model EPIC. The results of this study will be submitted to the USDOE Bioenergy Knowledge Discovery Framework as a way to contribute to the development of a sustainable bioenergy industry. This work provided the opportunity to test the hypothesis that marginal lands can serve as sources of cellulosic feedstocks and thus contribute to avoid potential conflicts between bioenergy and food production systems. This work, we believe, opens the door for further analysis on the characteristics of cellulosic feedstocks as major contributors to the development of a sustainable bioenergy economy. Examples of research questions that could be pursued with the modeling framework presented here include:

- How can the modeling framework be improved? (e.g., adding irrigation, improving winter wheat simulations)

- What is the performance of emerging biofuel feedstocks such as miscanthus, energy cane, and energy sorghum? Where are the best regions to grow them?

- What is the potential of marginal lands across the conterminous USA to provide sustainable levels of biomass feedstocks to the cellulosic ethanol industry?

- What are the full GHG impacts of diverse biofuel production systems? 


\subsection{References}

Bouton, J. H. 2002. Bioenergy crop breeding and production research in the southeast. Final report for 1996 to 2001. ORNL/SUB-02-19XSV810C/01. Available at http://www.osti.gov/bridge/ (verified 27 Apr. 2010). U.S. Department of Energy, Washington, DC.

Brown, R.A., and N.J. Rosenberg. 1999. Climate change impacts on the potential productivity of corn and winter wheat in their primary United States growing regions. Climatic Change 41:73- 107.

Cassida, K.A., J.P. Muir, M.A. Hussey, J.C. Read, B.C. Venuto, and W.R. Ocumpaugh. 2005. Biomass yield and stand characteristics of switchgrass in south central U.S. environments. Crop Sci. 45:673-681.

Crutzen P. J.; Mosier A. R.; Smith K. A., and W. Winiwarter. 2008. $\mathrm{N}_{2} \mathrm{O}$ release from agrobiofuel production negates global warming reduction by replacing fossil fuels. Atmos. Chem. Phys. 8:389-395.

CTIC: Crop residue management survey, Conservation Technology Information Center, West Lafayette, Indiana, USA, 2007.

Cavero J., R.E. Plant, C. Shennan, D.B. Friedman, J.R. Williams, J.R. Kiniry, and V.W. Benson. 1999. Modeling nitrogen cycling in tomato-safflower and tomato-wheat rotations. Agric Syst 60:123-135.

Chung, S.W., P.W. Gassman, L.A. Kramer, J.R. Williams, and R. Gu. 1999. Validation of EPIC for two watersheds in southwest Iowa. J. Environ. Qual. 28:971-979.

Dale, B.E., and S. Kim. 2004. Global potential bioethanol production from wasted crops and crop residues. Biomass Bioenergy 26:361-375.

Easterling, W.E., N.J. Rosenberg, M.S. McKenney, C.A. Jones, P.T. Dyke, and J.R. Williams. 1992. Preparing the erosion productivity impact calculator (EPIC) model to simulate crop responses to climate change and the direct effects of $\mathrm{CO}_{2}$. Agric. For. Meteorol. 59:17-34.

Egbendewe-Mondzozo A., S.M. Swinton, R.C. Izaurralde, D.H. Manowitz, and X. Zhang. Biomass supply from alternative cellulosic crops and crop residues: A spatially-explicit bioeconomic modeling approach. Biomass Bioenergy doi:10.1016/j.biombioe.2011.09.010.

Eggemeyer, K.D., T. Awada, D.A. Wedin, F.E. Harvey, and X. Zhou. 2006. Ecophysiology of two native invasive woody species and two dominant warm-season grasses in the semiarid grasslands of the Nebraska Sandhills. http://digitalcommons.unl.edu/natrespapers/38/.

EISA [Energy Independence and Security Act]. 2007. H.R. $6110^{\text {th }}$ Congress of the United States of America, Government Printing Office, Washington, DC. 309 pp.

Fargione J., J. Hill, D. Tilman, S. Polasky, and P. Hawthorne. 2008. Land clearing and the biofuel carbon debt. Science 319:1235-1238.

Farr, T.G., P.A. Rosen, E. Caro, et al. 2007. The shuttle radar topography mission. Review of Geophysics 45, RG2004 doi:10.1029/2005RG000183.

Fike, J.H., D.J. Parrish, D.D. Wolf, J.A. Balasko, J.T. Green, Jr., M. Rasnake, and J.H. Reynolds. 2006. Long-term yield potential of switchgrass-for-biofuel systems. Biomass Bioenergy 30:198-206.

Fuentes, R.C., and C.M. Taliaferro. 2002. Biomass yield stability of switchgrass cultivars. Trends in New Crops and New Uses. p. 276-282. In J. Janick and A. Whipkey (ed.) ASHS Press, Alexandria, VA.

Gassman, P.W., J. R. Williams, V.W. Benson, R.C. Izaurralde, L.M. Hauck, C.A. Jones, J.D. Atwood, J.R. Kiniry, and J.D. Flowers. 2005. Historical development and applications of the EPIC and APEX models. CARD Working Paper 05-WP. Center for Agricultural and Rural 
Development, Iowa State University, Ames, Iowa, USA. Available at:

http://www.card.iastate.edu/publications/synopsis.aspx?id=763.

Gelfand, I., R. Sahajpal, X. Zhang, R.C. Izaurralde, K.L. Gross, and G.P. Robertson. Cellulosic biofuel production and $\mathrm{CO}_{2}$ mitigation potential from marginal lands in the US Midwest. (Submitted).

Gosselin, D. C., V. Sridhar, F. E. Harvey, and J. W. Goeke. 2006. Hydrological effects and groundwater fluctuations in interdunal environments in the Nebraska Sandhills. Great Plains Research 16: 17-28.

Izaurralde, R.C., N.J. Rosenberg, R.A. Brown, D.M. Legler, M. Tiscareño-López, and R. Srinivasan. 1999. Modeled effects of moderate and strong Los Niños on crop productivity in North America. Agric. For. Meteor. 94:259-268.

Izaurralde, R.C., N.J. Rosenberg, R.A. Brown, and A.M. Thomson. 2003. Integrated assessment of Hadley Centre climate change projections on water resources and agricultural productivity in the conterminous United States. II. Regional agricultural productivity in 2030 and 2095. Agric. For. Meteor. 117:97-122.

Izaurralde, R.C., J.R. Williams, W.B. McGill, N.J. Rosenberg, and M.C. Quiroga Jakas. 2006. Simulating soil C dynamics with EPIC: Model description and testing against long-term data. Ecol. Modelling 192:362-384.

Izaurralde, R.C., J.R. Williams, W.M. Post, A.M. Thomson, W.B. McGill, L.B. Owens, and R. Lal. 2007. Long-term modeling of soil $\mathrm{C}$ erosion and sequestration at the small watershed scale. Climatic Change 80:73-90.

Izaurralde, R.C., W.B. McGill, and J.R. Williams. 2012. Development and application of the EPIC model for carbon cycle, greenhouse-gas mitigation, and biofuel studies. p. 409-429 In A. Franzluebbers, R. Follett, and M. Liebig (eds.) Managing Agricultural Greenhouse Gases: Coordinated agricultural research through GRACEnet to address our changing climate, Elsevier, Amsterdam.

Jones, C.A., P.T. Dyke, J.R. Williams, J.R. Kiniry, V.W. Benson, and R.H. Griggs. 1991. EPIC: an operational model for evaluation of agricultural sustainability. Agric. Syst. 37:341-350.

Kiniry, J.R., D.J. Major, R.C. Izaurralde, J.R. Williams, P.W. Gassman, M. Morrison, R. Bergentine, and R.P. Zentner. 1995. EPIC model parameters for cereal, oilseed, and forage crops in the northern Great Plains region. Can. J. Plant Sci. 75:679-688.

Kiniry, J.R., M.A. Sanderson, J.R. Williams, C.R. Tischler, M.A. Hussey, W.R. Ocumpaugh, J.C. Read, G. van Esbroeck, and R.L. Reed. 1996. Simulating Alamo switchgrass with the ALMANAC model. Agron. J. 88:602-606.

Klingebiel, A.A., and P.H. Montgomery. 1961. Land Capability Classification. Agriculture Handbook No. 210, Soil Conservation Service, U.S, pp. 1-3. Department of Agriculture, Washington, DC.

Legler, D.M., K.J. Bryant, and J.J. O'Brien. 1999. Impact of ENSO-related climate anomalies on crop yields in the US. Climatic Change 42:351-375.

Lemus, R., E.C. Brummer, K.J. Moore, N.E. Molstad, C.L. Burras, and M.F. Barker. 2002. Biomass yield and quality of 20 switchgrass populations in southern Iowa, USA. Biomass Bioenergy 23:433-442.

Monteith, J.L., 1977. Climate and the efficiency of crop production in Britain. Philos. Trans. R. Soc. London B 281:277-294.

NRC. 2011. Renewable fuel standard: Potential Economic and Environmental effects of U.S. Biofuel Policy. Committee on Economic and Environmental Impacts of Increasing Biofuels Production, National Research Council, National Academy Press, Washington, DC. 423 pp.

Perlack, R.D., B.J. Stokes (Leads). 2011. U.S. Billion-Ton Update: Biomass Supply for a Bioenergy and Bioproducts Industry. Report No. ORNL/TM-2011/224, Oak Ridge National Laboratory, Oak Ridge, TN. 227 pp. 
Puurveen, H., R.C. Izaurralde, D.S. Chanasyk, J.R. Williams, and R.F. Grant. 1997. Evaluation of EPIC's snowmelt and water erosion submodels using data form the Peace River Region of Alberta. Can. J. Soil Sci. 77:41-49.

Robertson, G.P., V.H. Dale, O.C. Doering, S.P. Hamburg, J.M. Melillo, M.M. Wander, W.J. Parton, P.R. Adler, J.N. Barney, and R.M. Cruse, C.S. Duke, P.M. Fearnside, R.F. Follett, H.K. Gibbs, J. Goldemberg, D.J. Mladenoff, D. Ojima, M.W. Palmer, A. Sharpley, L. Wallace, K.C. Weathers, J.A. Wiens, and W.W. Wilhelm. 2008. Sustainable biofuels redux. Science 322:49-50.

Roloff, G., R. de Jong, and M.C. Nolin. 1998. Crop yield, soil temperature and sensitivity of EPIC under central-eastern Canadian conditions. Can. J. Soil Sci. 78:431-439.

Searchinger, T., R. Heimlich, R.A. Houghton,F. Dong, A. Elobeid, J. Fabiosa, S. Tokgoz, D. Hayes, and T.H. Yu. Use of U.S.2008. Croplands for biofuels increases greenhouse gases through emissions from land-use change. Science 319:1238-1240.

Simley, J.D., and J.W.J. Carswell. 2009. The National Map - Hydrography. U.S. Geological Survey Fact Sheet 2009-3054, pp 4. Available at: http://pubs.usgs.gov/fs/2009/3054/ (accessed February 2011).

Sladden, S.E., D.I. Bransby, and G.E. Aiken. 1991. Biomass yield, composition, and production costs for eight switchgrass varieties in Alabama. Biomass Bioenergy 1:119-122.

Slater, S., K. Keegstra, and T.J. Donohue. 2010. The US Department of Energy Great Lakes Bioenergy Research Center: Midwestern biomass as a resource for renewable fuels. Bioenergy Res. 3:3-5.

Stockle, C.O., J.R. Williams, C.A. Jones, and N.J. Rosenberg. 1992a. A method for estimating the direct and climatic effects of rising atmospheric carbon dioxide on growth and yield of crops. I. Modification of the EPIC model for climate change analysis. Agric. Syst. 38:225238.

Stockle, C.O., P.T. Dyke, J.R. Williams, C.A. Jones, and N.J. Rosenberg. 1992b. A method for estimating the direct and climatic effects of rising atmospheric carbon dioxide on growth and yield of crops. II. Sensitivity analysis at three sites in the midwestern USA. Agric. Syst. 38:239-256.

Thomason, W.E., W.R. Raun, G.V. Johnson, C.M. Taliaferro, K.W. Freeman, K.J. Wynn, and R.W. Mullen. 2004. Switchgrass response to harvest frequency and time and rate of applied nitrogen. J. Plant Nutr. 27:1199-1226.

Thomson, A.M., R.A. Brown, S.J. Ghan, R.C. Izaurralde, N.J. Rosenberg, and L.R. Leung. 2002. Elevation dependence of winter wheat production in Eastern Washington State with climate change: A methodological study. Climatic Change 54:141-164.

Tagil, S., and J. Jenness. 2008. GIS-based automated landform classification and topographic, landcover and geologic attributes of landforms around the Yazoren Polje, Turkey. J. Applied Sci. 8: 910-921.

Tilman, D., R. Socolow, J.A. Foley, J. Hill, E. Larson, L. Lynd, S. Pacala, J. Reilly, T. Searchinger, C. Somerville, and R. Williams. 2009. Beneficial biofuels - the food, energy, and environment trilemma. Science 325:270-271.

USDA (United States Department of Agriculture). 2011. Fertilizer use and price. Available at http://www.ers.usda.gov/Data/FertilizerUse/, accessed on Oct. 18, 2011.

USDA NASS (United States Department of Agriculture National Agricultural Statistics Service). 1997. Usual Planting and Harvesting Dates for U.S. Field Crops. Available at http://www.nass.usda.gov/Publications/Usual_Planting_and_Harvesting_Dates/uph97.pdf, accessed on Oct. 18, 2011.

Williams, J.R., C.A. Jones, J.R. Kiniry, and D.A. Spanel. 1989. The EPIC crop growth model. Trans. ASAE 32:497-511.

Williams, J.R. 1995. The EPIC model. In Computer Models of Watershed Hydrology (Ed.: V.P. Singh). Water Resources Publications, Highlands Ranch, CO. pp 909-1000. 
Wullschleger, S.D., E.B. Davis, M.E. Borsuk, C.A. Gunderson, and L.R. Lynd. 2010. Biomass production in switchgrass across the United States: Database description and determinants of yield. Agron. J. 102:1158-1168.

Zak, D.R., D.F. Grigal, S. Gleeson, and D. Tilman. 1990. Carbon and nitrogen cycling during old field succession: Constraints on plant and microbial biomass. Biogeochemistry 11:111-129.

Zhang, X., R.C. Izaurralde, D. Manowitz, T.O. West, W.M. Post, A.M. Thomson, V.P. Bandaru, J. Nichols, and J.R. Williams. 2010. An integrative modeling framework to evaluate the productivity and sustainability of biofuel crop production systems. Global Change Biol. Bioenergy 2:258-277. 


\subsection{Appendix I}

Appendix I: Production accuracy of CDL 2010 for identifying three major crops.

\begin{tabular}{|c|c|c|c|c|c|c|c|}
\hline State & Corn & Soybean & $\begin{array}{l}\text { Winter } \\
\text { Wheat }\end{array}$ & State & Corn & Soybean & $\begin{array}{l}\text { Winter } \\
\text { Wheat }\end{array}$ \\
\hline AL & $87.9 \%$ & $76.9 \%$ & $18.7 \%$ & MS & $91.8 \%$ & $93.3 \%$ & $61.8 \%$ \\
\hline AR & $87.9 \%$ & $91.2 \%$ & $0.0 \%$ & MT & $71.4 \%$ & $17.3 \%$ & $85.9 \%$ \\
\hline DE_MD & $94.1 \%$ & $91.1 \%$ & $23.5 \%$ & $\mathrm{NC}$ & $94.2 \%$ & $85.0 \%$ & $23.8 \%$ \\
\hline $\mathrm{GA}^{-}$ & $88.3 \%$ & $52.1 \%$ & $19.2 \%$ & ND & $91.0 \%$ & $95.4 \%$ & $84.3 \%$ \\
\hline
\end{tabular}




\subsection{Appendix II - Publications and Presentations}

Bandaru, V., W. Post, S. Kang, T. West, R. Izaurralde, and X. Zhang. Integrated Assessment Approach to Identify Potential Marginal Lands for Alternative 2010. Bio-Fuel Crop Production. ASA, CSSA, and SSSA 2010 International Annual Meetings, Oct. 31 - Nov. 4, Long Beach, CA.

Egbendewe-Mondzozo, A, SM Swinton, C Izaurralde, D Manowitz, and X Zhang. 2011. Biomass supply from alternative cellulosic crops, and crop residues: A watershed scale bioeconomic modeling approach. Ecological Society of America, Annual Meeting, Austin, TX.

Egbendewe-Mondzozo, A., S.M. Swinton, R.C. Izaurralde, D.H. Manowitz and X. Zhang. 2011. Biomass Supply From Cellulosic Crops and Crop Residues in Southwest Michigan. GLBRC 2011 Retreat, Kalamazoo, MI.

Gelfand, I., R. Sahajpal, X. Zhang, R.C. Izaurralde, and G.P. Robertson. 2010. Biofuel production and climate mitigation potential from marginal lands in US North Central region. 2010 AGU Fall Meeting, San Francisco, CA.

Gelfand, I., R. Sahajpal, X. Zhang, R.C. Izaurralde, K.L. Gross, and G.P. Robertson. Sustainable bioenergy production from marginal lands in the US Midwest. (Submitted).

Izaurralde, R.C., X. Zhang, D.H. Manowitz, and R. Sahajpal, Water-cycle implications of biofuel production systems, GLBRC 2011 Retreat, May, 2011, South Bend, IN.

Izaurralde, R.C., X. Zhang, Sustainable biofuel operating space: multi-criteria assessment and multi-objective optimization. GLBRC 2011 Retreat, May, 2011, South Bend, IN.

Izaurralde, R.C., W.B. McGill, and J.R. Williams. 2012. Development and application of the EPIC model for carbon cycle, greenhouse-gas mitigation, and biofuel studies. p. 409-429 In A. Franzluebbers, R. Follett, and M. Liebig (eds.) Managing Agricultural Greenhouse Gases: Coordinated agricultural research through GRACEnet to address our changing climate, Elsevier, Amsterdam.

Kang, S, WM Post III, J Nichols, D Wang, C Izaurralde, TO West, P Bandaru, X Zhang, D Manowitz, and AM Thomson. 2011. Delineating a hierarchal definition of marginal land using simulation results. Ecological Society of America, Annual Meeting, Austin, TX.

Kang, S., J. Nichols, D. Wang, W.M. Post, R.C. Izaurralde, X. Zhang, D.H. Manowitz, and V. Bandaru. Using high-performance biophysical simulations for sustainability assessment and design of bioenergy production systems: a preliminary case study in RIMA of Wisconsin. GLBRC 2011 Retreat, May 2011, South Bend, IN.

Kang, S., V. Bandaru, W. Post, T. West, J. Nichols, R. Izaurralde, X. Zhang, A. Thomson, and D. Manowitz. 2010. Marginal Land Assessment and Management for Bioenergy Production: A Case Study at RIMA of Michigan. ASA, CSSA, and SSSA 2010 International Annual Meetings, Oct. 31 - Nov. 4, Long Beach, CA.

Manowitz, D and RC Izaurralde. 2011 Modeling production, net greenhouse gas emissions, and related environmental impacts of bioenergy systems at plot scale. Ecological Society of America, Annual Meeting, Austin, TX.

Nichols, J.A, S. Kang, D. Wang, W.M. Post, R.C. Izaurralde, X. Zhang, D.H. Manowitz, and V. Bandaru. HPC-EPIC for high resolution simulation of environmental and sustainability assessment, GLBRC 2011 Retreat, May 2011, South Bend, IN.

Sahajpal, R, TD Meehan, RC Izaurralde, D Manowitz, X Zhang, C Gratton, BP Werling and DA Landis. 2011. Integrating biodiversity estimation into the EPIC model. Ecological Society of America, Annual Meeting, Austin, TX.

Sahajpal, R., R.C. Izaurralde, and X. Zhang. 2010. Siting cellulosic ethanol biorefineries based on perennial biomass crop production on marginal lands in the 10-State U.S. North Central Region. GLBRC 2010 Retreat, South Bend, IN. 
Sahajpal, R., R.C. Izaurralde, and X. Zhang. Identifying Marginal Lands Suitable for Cultivation for Perennial Biomass Crop Production in the Sandhills of Nebraska, GLBRC 2011 Retreat, May, 2011, South Bend, IN.

Thomson, A.M, R.C. Izaurralde, K.V. Calvin, X. Zhang, M.A. Wise, and T.O. West. 2010. Integrating a Detailed Agricultural Model in a Global Economic Framework: New methods for assessment of climate mitigation and adaptation opportunities. 2010 AGU fall meeting, San Francisco, CA.

Wang, D., Nichols, J., S. Kang, W.M. Post, R.C. Izaurralde, X. Zhang, D.H. Manowitz, and V. Bandaru. Large-scale data management system for spatially-explicit agroecosystem modeling. GLBRC 2011 Retreat, May 2011, South Bend, IN.

Zhang, X, RC Izaurralde, D Manowitz, TO West, WM Post, AM Thomson, P Bandaru, J Nichols, and J Williams. 2011. SEIMF: A spatially-explicit integrative modeling framework to evaluate the productivity and sustainability of biofuel crop production systems. Ecological Society of America, Annual Meeting, Austin, TX.

Zhang, X., R.C. Izaurralde, A.M. Thomson, R. Sahajpal, D.H. Manowitz, and S.D. LeDuc, Assessment of Conservation Reserve Program (CRP) and Marginal Land-Use Change for Bioenergy Production. 2011 AAG Annual Meeting, April, 2011, Seattle, WA.

Zhang, X., R.C. Izaurralde, D. Manowitz, T.O. West, W.M. Post, A.M. Thomson, V.P. Bandaru, J. Nichols, and J.R. Williams. 2010. An integrative modeling framework to evaluate the productivity and sustainability of biofuel crop production systems. Global Change Biol. Bioenergy 2:258-277.

Zhang, X., R.C. Izaurralde, J.G. Arnold, N.B. Sammons, D.H. Manowitz, A.M. Thomson, J.R. Williams. 2011. Comment on "Modeling Miscanthus in the Soil and Water Assessment Tool (SWAT) to Simulate Its Water Quality Effects As a Bioenergy Crop". Environ. Sci. Tech. 45:6211-6212. 


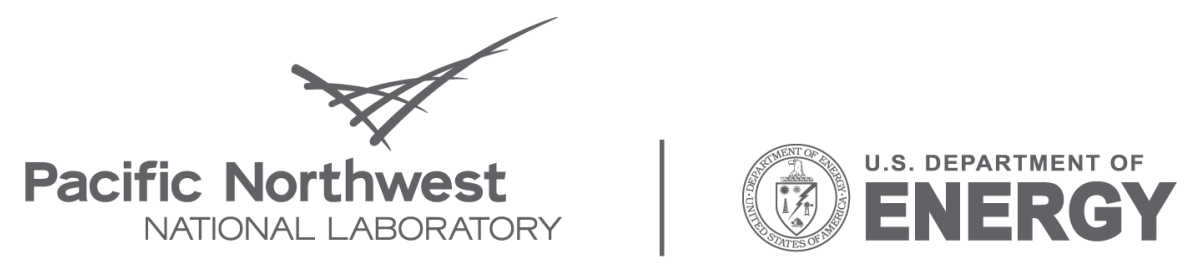

Proudly Operated by Battelle Since 1965

902 Battelle Boulevard

P.O. Box 999

Richland, WA 99352

1-888-375-PNNL (7665)

www.pnl.gov 